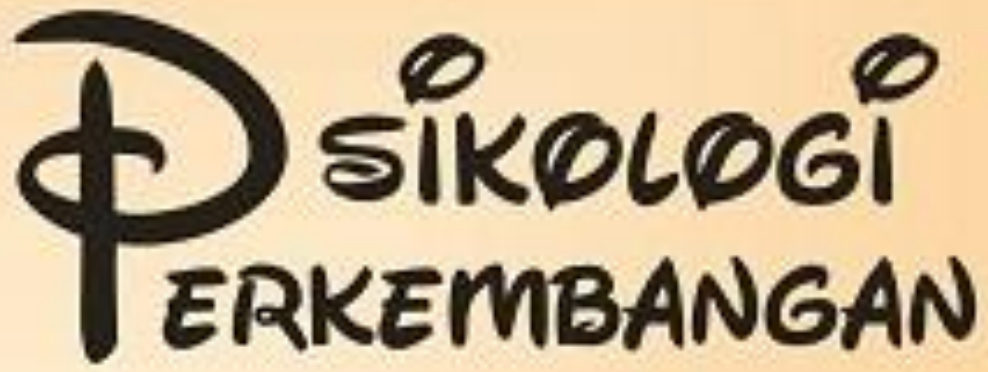

Dr. Eni Fariyatul Fahyuni, M.Pd.I

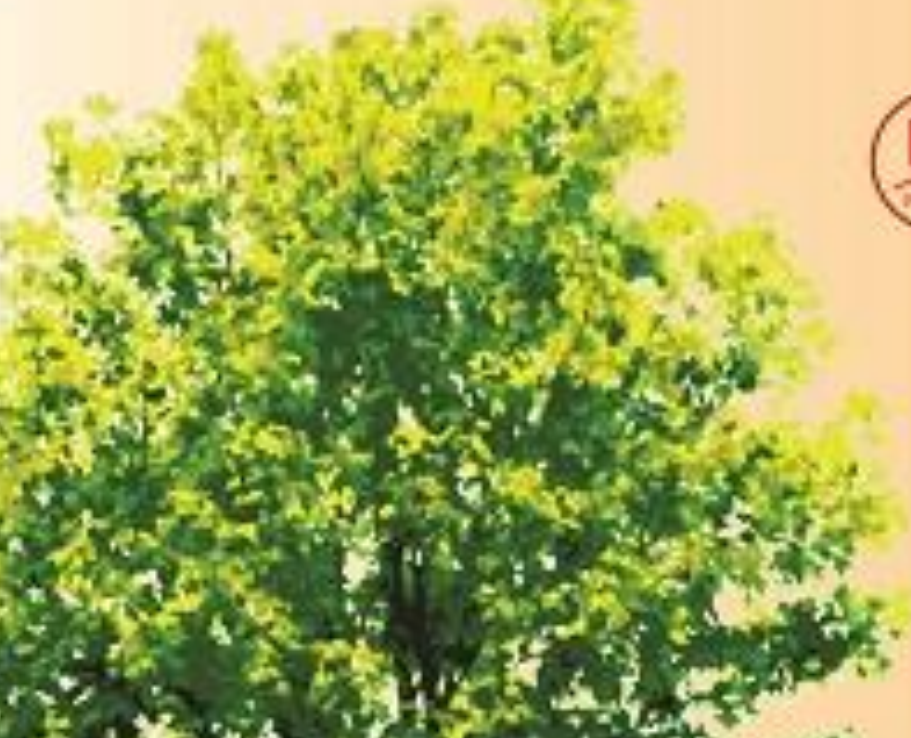

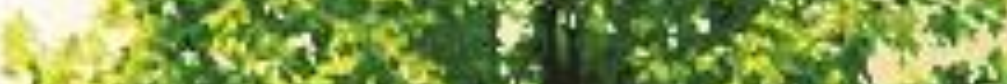

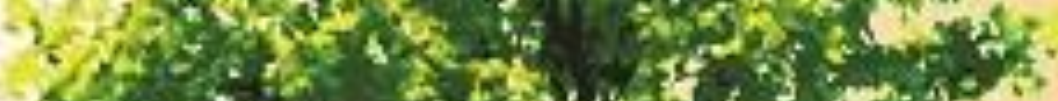

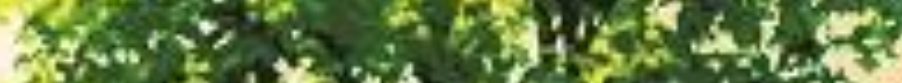

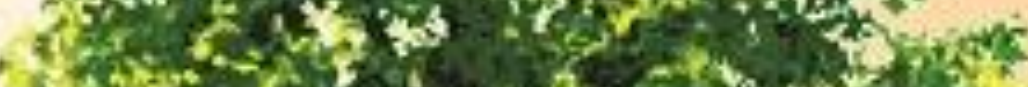

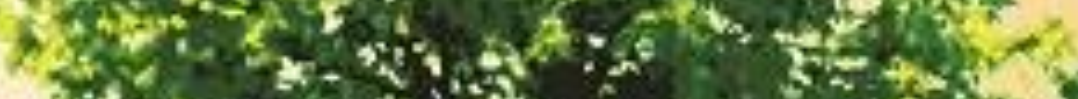

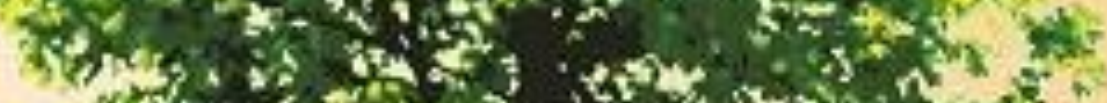

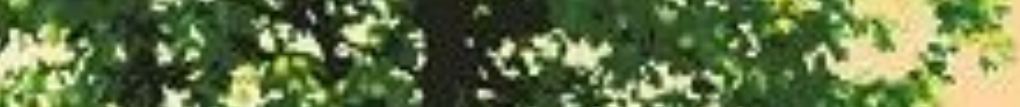

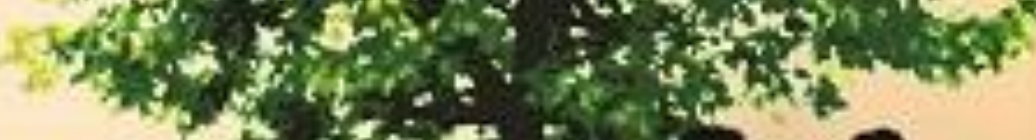

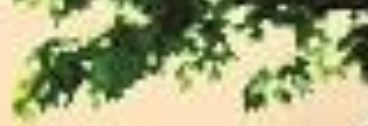
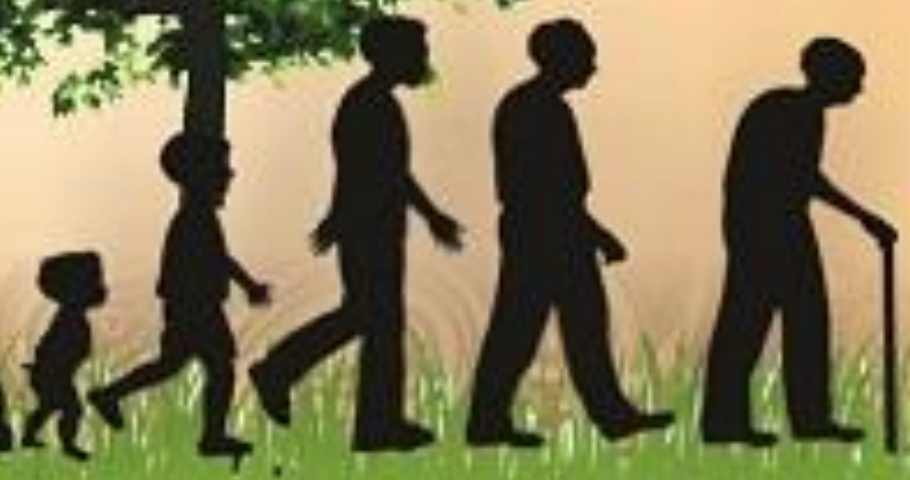


\title{
BUKU AJAR PSIKOLOGI PERKEMBANGAN
}

\author{
Penulis \\ Dr. Eni Fariyatul Fahyuni, M.Pd.I
}

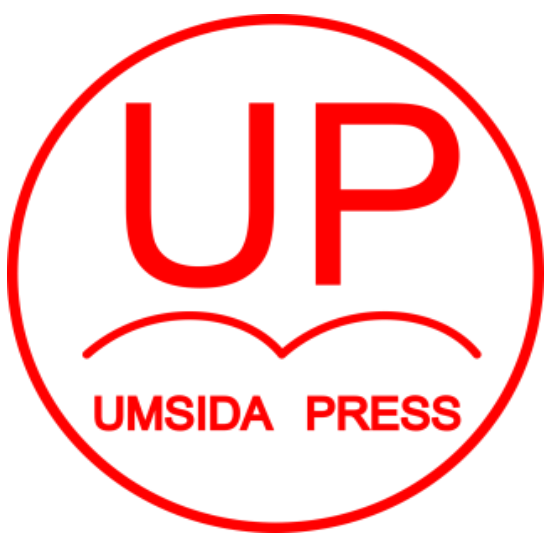

Diterbitkan oleh UMSIDA PRESS

Jl. Mojopahit 666 B Sidoarjo ISBN: 978-602-5914-61-4

Copyright@ 2019.

\section{Authors}

All rights reserved 
BUKU AJAR

PSIKOLOGI PERKEMBANGAN

Penulis :

Dr. Eni Fariyatul Fahyuni, M.Pd.I

ISBN : 978-602-5914-61-4

\section{Editor :}

Mohammad Sholeh, S.Pd, M.Pd

Design Sampul dan Tata Letak :

Yunita Khilyatun Nisa, S.TP

\section{Penerbit :}

UMSIDA Press

\section{Redaksi :}

Universitas Muhammadiyah Sidoarjo

Jl. Mojopahit No 666B

Sidoarjo, Jawa TImur

Cetakan pertama, Juni 2019

(C) Hak cipta dilindungi undang-undang

Dilarang memperbanyak karya tulis ini dengan suatu apapun tanpa ijin tertulis dari penerbit. 


\section{KATA PENGANTAR}

Puji syukur kepada Tuhan Yang Maha Esa, sehingga dapat dihasilkan buku ajar Psikologi Perkembangan. Penulis mengucapkan terima kasih kepada semua pihak yang telah memberikan bahan-bahan tulisan baik langsung maupun tidak langsung. Penulis juga mengucapkan terima kasih khususnya kepada:

1. Dr. Hidayatullah, M.Si pemangku pimpinan tertinggi yaitu Rektor Universitas Muhammadiyah Sidoarjo yang telah memberikan dan memfasilitasi dalam penulisan buku ajar Psikologi Perkembangan ini.

2. LP3iK Universitas Muhammadiyah Sidoarjo yang telah memfasilitasi dan mengkoordinasi dalam penulisan buku ajar ini.

3. Dr. Istikomah, M.Ag. sebagai Dekan Fakultas Agama Islam, Universitas Universitas Muhammadiyah Sidoarjo yang telah memberikan dukungan untuk mengikuti penulisan buku ajar ini.

4. Imam Fauji, Lc, M.Pd. sebagai Ketua Program Studi Pendidikan Agama Islam, Universitas Universitas Muhammadiyah Sidoarjo yang telah memberikan dukungan untuk penulisan buku ajar Psikologi Perkembangan ini.

Akhir kata, kritik dan saran diharapkan untuk penyempurnaan buku ajar ini. Harapan kami semoga buku ajar Psikologi Perkembangan dapat bermanfaat dan sebagai informasi pendukung yang dapat digunakan rujukan bagi mahasiswa, pendidik dan calon pendidik, serta praktisi pendidikan sebagai motivasi dalam berkarya khususnya pada 
bidang pembelajaran. Demikian semoga tulisan sederhana ini dapat bermanfaat bagi penulis khususnya dan para pembaca pada umumnya.

Sidoarjo, 21 Juni 2019 


\section{DAFTAR ISI}

Cover

Identitas Buku

Kata Pengantar

Daftar isi

BAB I Pertumbuhan dan Perkembangan _........................... 1

A. Definisi Pertumbuhan _............................................

B. Definisi Perkembangan _...................................... 3

C. Peran Kematangan dalam Perkembangan _................. 6

D. Semua Individu Berbeda 9

E. Setiap Tahap Perkembangan Beresiko ..................... 12

BAB II Masa Neonatal dan Pascanatal .......................... 17

A. Masa Bayi ..................................................

B. Penyesuaian Pascanatal _................................. 22

BAB III Masa Kanak-Kanak

A. Perkembangan Masa Kanak-Kanak _..................... 32

B. Ciri Awal Masa Kanak-Kanak _...................... 35

C. Tugas Perkembangan Masa Kanak-Kanak _............40

D. Kebiasaan Fisiologis _................................ 45

E. Keterampilan Masa Kanak-Kanak _...................... 46

F. Kemajuan Berbicara Awal _............................ 49

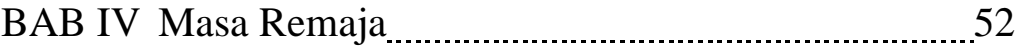

A. Karakteristik Masa Remaja _.............................. 52

B. Perubahan Masa Remaja _................................... 54

C. Konsep Tugas Perkembangan _............................ 60

BAB V Perkembangan Kemandirian Peserta Didik 63 

A. Kemandirian 63
B. Bentuk-Bentuk Kemandirian 65
C. Karakteristik Kemandirian ..................................... 67
D. Pentingnya Kemandirian Peserta Didik _................... 69

BAB VI Perkembangan Spiritual Peserta Didik _.............. 73
A. Pengertian Spiritual 73
B. Spiritual dan Religiusitas 75
C. Spiritualitas dalam Psikologi Humanistik 90
D. Spiritualitas dalam Psikologi Transpersonal 94
E. Konsep Acuan yang Relevan 97

Daftar Pustaka 


\section{DAFTAR GAMBAR}

Gambar 1 Pertumbuhan dan Perkembangan _......................... 4

Gambar 2 Pola Perkembangan Fisik _................................ 8

Gambar 3 Tingkatan Usia Pertumbuhan .............................. 11

Gambar 4 Masa Bayi Neonatal _....................................... 19

Gambar 5 Periodesasi Perkembangan Manusia _.................. 33

Gambar 6 Masa Awal Kank-Kanak ...................................... 37

Gambar 7 Masa Menjelajah Lingkungan .............................. 39

Gambar 8 Komunikasi Sarana Sosial _................................ 51

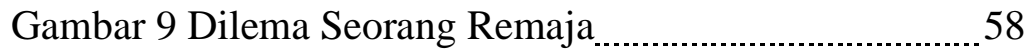

Gambar 10 Konsep Tugas Perkembangan _......................... 60

Gambar 11 Kemandiiran Masa Remaja ............................... 64

Gambar 12 Kemandirian Peserta Didik ............................. 70

Gambar 13 Tumbuh Kembah Spiritual Remaja

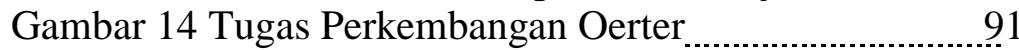

Gambar 15 Jarak Perkembangan Individu .......................... 94

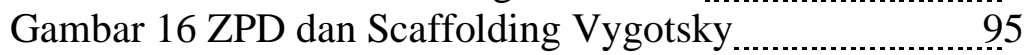

Gambar 17 Konsep Belajar Vygotsky _.............................. 96

Gambar 18 Konsep ZPD 


\section{BAB I PERTUMBUHAN DAN PERKEMBANGAN}

\section{A. Definisi Pertumbuhan}

Psikologi perkembangan sebagai cabang ilmu psikologi menelaah pelbagai perubahan intra individual dan perubahan inter individual yang terjadi di dalam perubahan intra individual. Tugasnya, seperti yang dikatakan oleh La Bouvie, "tidak hanya mendiskripsikan perubahan-perubahan perilaku menurut tingkat usia sebagai masalah hubungan anteseden (gejala yang mendahului) dan konsekuensinya". Beberapa psikologi perkembangan mempelajari perubahan dalam perkembangan yang mencakup seluruh rentang kehidupan dari pembuhan sampai akhir hayat. Dengan begitu, mereka berusaha menggambarkan dengan sempurna pertumbuhan dan kemunduran. Ahli-ahli lainnya hanya mempelajari salah satu bagian dari rentang kehidupan masa kanak-kanak, masa dewasa atau usia lanjut.

Pada mulanya seperti kata Siegel "psikologi perkembangan mengkhususkan dari pada masalah usia dan tahapan-tahapan. Para penyelidik terdorong untuk mempelajari usia yang khas dan tertentu di mana terjadi berbagai tahapan perkembangan". Bidang tempat riset yang dipusatkan merupakan bidang yang dianggap penting untuk penyesuian evolusimanusia. Sebagaian besar riset dipusatkan pada anak-anak usia prasekolah, usia sekolah, dan remaja. Baru kemudian riset diperluas ke bawah, pertama ke tahap kelahiran lalu ke pembuahan, dan selanjutnya ke atas, ke tahap dewasa, lanjut usia, dan akhirnya usia pertengahan.

Terdapat alasan utama mengapa terjadi perbedaan penekanan pada psikologi perkembangan. Pertama, penelitian terhadap periode tertentu dalam pola perkembangan sangat dipengaruhi oleh keinginan untuk memecahkan beberapa masalah praktis dan masalah-masalah 
yang berkaitan dengan periode itu. Misalnya, riset mengenai usia pertengahan dikembangkan dari realisasi bahwa penyesuaian diri yang baik pada tahun-tahun kehidupan berikutnya sangat bergantung pada seberapa jauh seseorang dapat menyesuaikan diri, baik terhadap perubahan-perubahan fisik maupun psikologi yang biasanya terjadi pada usia pertengahan, karena dalam tahun terakhir ini pusat perhatian psikologi perkembangan telah berubah, maka terdapat kesenjangan dalam pengetahuan kita tentang gejala perkembangan yang berbeda, yang khas pada berbagai periode. Kesenjagan ini juga disebabkan antara lain sulitnya mempelajari keanekaan perilaku yang khas pada suatu periode tertentu, khususnya kesulitan memperoleh sampel subjek usia tertentu dan untuk menemukan metode yang tepat untuk mempelajari pola perilaku.

Alasan kedua mengapa terjadi penekanan yang berbeda adalah bahwa lebih sulit mempelajari manusia pada tahap-tahap kehidupan yang lain. Misalnya, untuk memperoleh subjek-subjek usia pertengahan dan usia lanjut adalah lebih sulit dibandingkan dengan mencari subjek-subjek usia prasekolah, dan usia sekolah atau remaja.

Pada saat ini ahli psikologi perkembangan mempunyai enam tujuan pokok yaitu : (1) menemukan perubahan-perubahan apakah yang terjadi pada usia yang umum dan yang khas dalam penampilan perilaku, minat, dan tujuan dari masing-masing periode perkembangan; (2) menemukan kapan perubahan-perubahan ini terjadi; (3) menemukan sebab-sebabnya; (4) menemukan bagaimana perubahan itu mempengaruhi perilaku; (5) menemukan dapat tidaknya perubahan-perubahan itu diramalkan; dan (6) menemukan apakah perubhan itu bersifat individual atau universal. 


\section{B. Definisi Perkembangan}

Istilah perkembangan berarti serangkaian perubahan progesif yang terjadi sebagai akibat dari proses kematangan dan pengalaman. Ini berarti bahwa perkembangan bukan sekedar penambahan beberapa sentimeter pada tinggi badan seseorang atau peningkatan kemampuan seseorang, melinkan suatu proses integrasi dari banyak struktur dan fungsi yang kompleks. Pada dasarnya ada dua proses perkembangan yang saling bertentangan yang terjadi secara serempak selama kehidupan, yaitu pertumbuhan atau evolusi dan kemunduran atau involusi(Fahyuni, 2016). Keduanya mulai dari pembuhan dan berakhir dengan kematian. Dalam tahun pertama pertumbuhan berperan, sekalipun perubahan yang bersifat kemunduran terjadi semenjak kehidupan janin. Pada bagian kehidupan selanjutnya, kemunduran yang berperan sekalipun pertumbuhan tidak berhenti; rambut tumbuh terus dan sel-sel terus menerus berganti.

Manusia tidak pernah statis. Semenjak pembuahan hingga akhir ajal selalu terjadi perubahan, baik dalam kemampuan fisik amupun kemampuan psikologis. Piaget menjelaskan bahwa struktur itu "tidak pernah statis dan sudah ada semenjak awal." Dengan perkatan lain, organisme yang matang selalu mengalami perubahan yang progresif sebagai tanggapan terhadap kondisi yang bersifat pengalaman dan perubahan-perubahan itu mengakibatkan jaringan interaksi yang majemuk. 


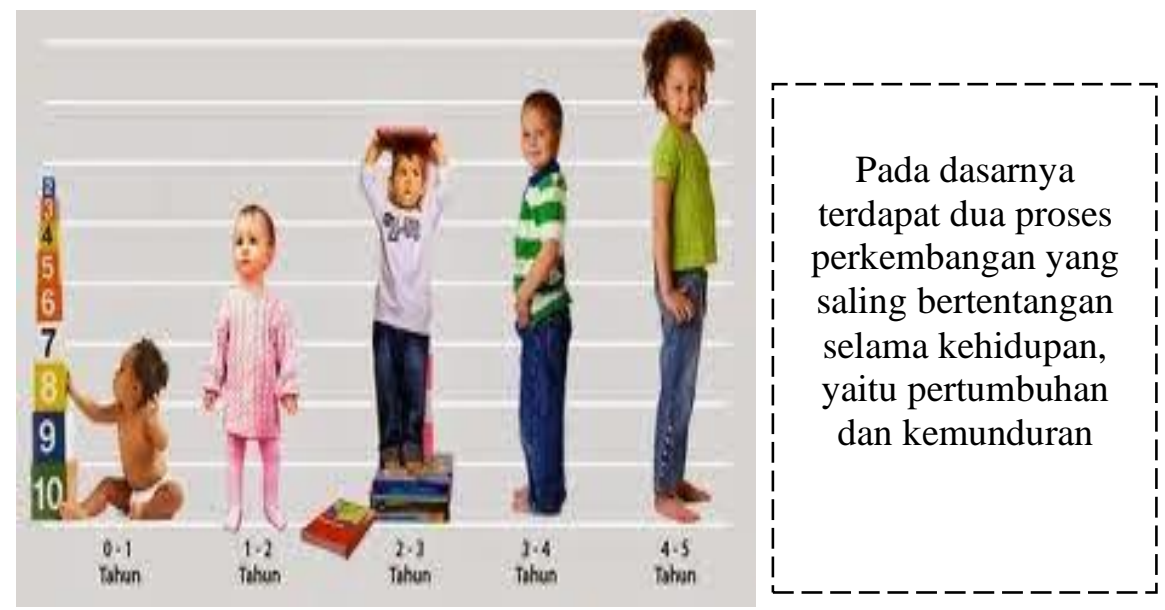

Gambar 1. Pertumbuhan Dan Kemunduran Manusia

Sekalipun perkembangan adalah berkesinambungan, perkembangan itu merupakan proses siklikal dengan berkembangnya kemampuan-kemampuan dan kemudian menghilang, dan yang akan muncul kembali pada uisa berikutnya(Murni, 2017). Dalam hal ini bukan berkesinambungan dalam arti senantiasa meningkat, tetapi merupakan serangkaian gelaombang dengan seluruh bagian perkembangan yang terjadi lagi secara berulang. Misalnya, dijelaskan Bower, bayi yang baru lahir dapat berjalan kalau dituntun, kemudian kebiasaan ini menghilang dan hanya akan muncul lagi pada uisa delapan atau sepuluh bulan. Selanjutnya dikatakan bahwa berbagai penjelasan mengenai "proses pengulangan dalam perkembangan ini kelihatannya berbeda-beda tergantung pada pengulangan tertentu mana yang akan dijelaskan. Namun dari semua penjelasan itu ada kesamaannya yakni bahwa kesemuanya mempertahankan anggapan bahwa pertumbuhan psikologis meskipun kelihatan terbalik tumbuhnya merupakan proses yang berkesinambungan dan bersifat tambahan". Apabila terjadi regresi pada tingkat usia muda, biasanya 
ada sebabnya, seperti regresi ke arah perilaku yang aneh yang terjadi bersamaan dengan pertumbuhan yang cepat pada tingkatan usia pubertas.

Seringkali pola perubahan itu mirip kurva berbentuk lonceng, pada awalnya naik dengan tiba-tiba, mendatar selama usia pertengahan, dan turun secara perlahan atau mendadak pada uisa lanjut. Perlu dicatat bahwa pola ini tidak pernah berbentuk satu garis lurus walaupun dapat terjadi periode stabil yang singkat atau berkepanjangan dalam perkembangan kemampuan yang berbeda. Berbagai perubahan dalam perkembangan bertujuan untuk memungkinkan orang menyesuaikan diri dengan lingkungan di mana ia hidup. Untuk mencapai tujuan ini, maka realisasi diri atau yang biasanya disebut "aktualisasi diri" adalah sangat penting. Namun tujuan ini tidak pernah statis. Tujuan dapat dianggap sebagai suatu dorongan untuk malakukan sesuatu yang tepat untuk dilakukan, untuk menjadi manusia seperti yang diinginkan baik secara fisik maupun psikologis.

Bagaimana manusia mengungkapkan dorongan ini tergantung pada kemampuan-kemampuan bawaan dan latihan yang diperoleh tidak hanya selama masa kanak-kanak tetapi juga saat usianya meningkat dan sampai pada saat ia menjumpai tekanan-tekanan yang lebih besar untuk menyesuaikan diri dengan harapan-harapan masyarakat. Realisasi diri memainkan peranan penting dalam kesehatan jiwa, maka orang yang berhasil menyesuaikan diri dengan baik secara pribadi dan sosial, harus mempunyai kesempatan untuk mengungkapkan minat, dan keinginannya dengan cara yang memuaskan dirinya. Tetapi pada saat yang sama harus menyesuaikan dengan standar-standar yang diterima. Kurangnya kesempatankesempatan ini akan menimbulkan kekecewaan dan sikap-sikap 
negatif pada umumnya terhadap orang lain, dan terhadap kehidupan pada umumnya.

\section{Peran Kematangan dan Belajar dalam Perkembangan}

Perkembangan adalah kematangan dan belajar memainkan peranan yang penting dalam perkembangan. Kematangan adalah terbukannya sifat-sifat bawaan individu. Dalam fungsi phylogenetik, fungsi-fungsi yang lazim ditemui pada manusia seperti merangkak, duduk, dan berjalan perkembangan berasal dari kematangan. Belajar, dalam bentuk pelatihan, sedikit manfaatnya, sekalipun pengenalan terhadap lingkungan mengurangi kesempatan untuk praktek dapat menghambat perkembangan. Kematangan memberikan bahan dasar untuk belajar dan menentukan pola-pola umum dan urutan-urutan perilaku yang umum.

Belajar adalah perkembangan yang berasal dari latihan dan usaha pada pihak individu. Dalam fungsi ontogenetik fungsi-fungsi yang khusus pada individu seperti menulis, mengemudi atau berenang belajar dalam bentuk pelatihan adalah sangat penting. Tanpa fungsi tersebut perkembangan tidak akan terjadi. Tiga fakta penting timbul dari pengetahuan kita akan saling keterbutuhan antara kematangan dan belajar sebagai penyebab perkembangan. Pertama, karena manusia mampu belajar, mka keanakaan mungkin terjadi. Perbedaanperbedaan individu dalam kepribadian, sikap-sikap dan ola-pola perilaku terjadi bukan karena kematangan saja tetapi dari kematangan dan belajar. Kedua, kematangan memberi batasan di mana perkembangan tidak dapat memperoleh kemajuan sekalipun dengan metode belajar yang paling disukai dan dengan motivasi yang kuat dari pihak yang belajar. Kegagalan dapat disebabkan oleh kesulitan genetis potensi-potensi yang genetis berkembang. Ketiga, ada "jadwal" yang pasti untuk belajar. Individu tidak dapat belajar sampai dirinya siap. 
"kesiapan perkembangan" atau kesiapan untuk belajar, menentukan saat kapan belajar itu dapat dan harus dilakukan. Harris menekankan pentingnya untuk memperoleh kesempatan belajar bila individu itu sudah siap. "Mungkin, orang yang terlambat untuk melakukan pelatihannya tidak akan merealisasikan segala kemampuannya.

Fakta ketiga yang penting tentang perkembangan adalah bahwa perkembangan itu mengikuti pola tertentu dan yang dapat diramalkan. Misalnya, pola-pola teratur dari perkembangan fisik, motor, bicara, dan perkembangan intelektual. Pola perkembangan fisik dan motor ditunjukkan dalam Gambar 2. yang menggambarkan hukum arab perkembangan yang disebut "hukum cephalocaudal" yang menetapkan bahwa perkembangan menyebar ke seluruh tubuh dari kepala ke kaki dan "hukum proximodistal" yang menerapkan bahwa perkembangan menyebar keluar dari titik poros sentral tubuh ke anggota-anggota tubuh.

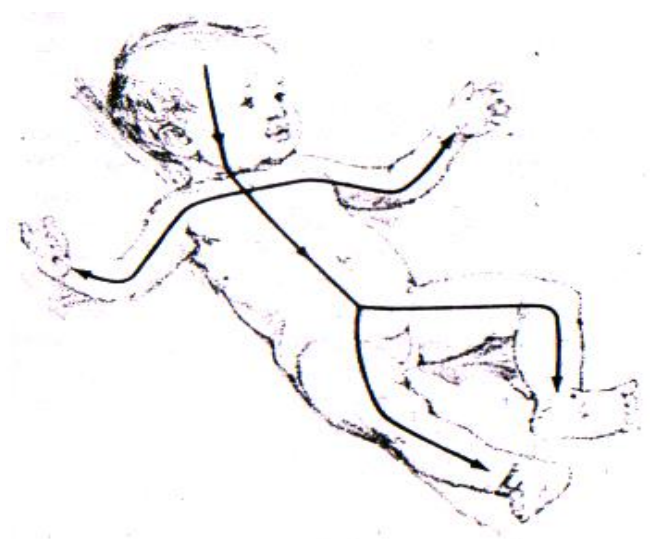

Gambar 2. Pola perkembangan fisik dan motor mengikuti hukum arah perkembangan yang menyebutkan bahwa perkembangan mulai dari kepala ke kaki dan dari batang tubuh ke anggota tubuh. (Diambil dari 
E.L. Vincent and P.C. Martin. Human psychological development. New York: Roland Prees 1961. Digunakan dengan izin).

Jika kondisi lingkungan tidak menghambat, perkembangan akan mengikuti pola yang berlaku umum. Misalnya, bayi yang merangkak sebelum berlajalan dan minat terhadap seks baru muncul setelah terjadi perubahan-perubahan pubertas. Tidak terdapat kejelasan yang menyatakan bahwa individu-individu memiliki pola perkembangan sendiri, walaupun ternyata bahwa laju perkembangan berbeda dari satu individu dengan individu lain. Kondisi lingkungan penting karena kondisi ini memungkinkan kita meramalkan apa yang akan dilakukan orang pada usia tertentu dan merencanakan pendidikan dan pelatihan mereka sesuai dengan pola ini. Kalau perkembangan tidak dapat diramalkan, tidak mungkin merencanakan setiap periode rentang kehidupan. Misalnya, orang-orang usia pertengahan tidak akan mempunyai orientas tasi ke depan untuk membuat rencana sehubungan dengan menurunnya kesehatan dan berkurangnya penghasilan dengan bertambahnya usia mereka, dan orang tua tidak mampu membuat rencana pelatihan yang diperlukan untuk anak-anak mereka sehingga sesuai dengan masa hidup dewasanya.

\section{Semua Individu Berbeda}

Semua individu adalah berbeda. Seperti yang ditekankan oleh Dobzhansky, "Setiap orang secara biologis dan genetis benar-benar berbeda satu dari yang lainnya, bahkan dalam kasus bayi kembar (30). Dan terbukti bahwa perbedaan-perbedaan itu semakin bertambah, bukannya mengurang semenjak anak-anak beranjak dari masa kanakkanak ke masa remaja dan akhirnya ke usia lanjut. Neugarten mengemukakan bahwa "orang-orang dewasa tidak saja jauh lebih kompleks ketimbang anak-anak, tetapi juga mereka lebih berbeda satu dari yang lainnya, dan perbedaan ini semakin meningkatkan dengan 
beralihnya mereka dari usia muda ke usia lanjut. Karena semua individu berbeda, tidak dapat diharapkan bahwa dua orang tertentu akan bereaksi dengan cara yang sama terhadap rangsangan lingkungan yang sama. Anak-anak penakut tidak sama reaksinya dengan anakanak yang agresif. Dan mereka yang tenang dan santai tidak merasa terganggu dengan kepindahan keluarga dibandingkan dengan mereka yang pemalu dan peka.

Sesungguhnya tidak ada dua individu yang memiliki sifat-sifat bawaan dan pengalaman-pengalaman lingkungan yang sama, orang tidak pernah dapat meramalkan secara tepat bagaimana orang akan bereaksi terhadap suatu situasi, sekalipun ada informasi yang luas tentang kemampuan-kemampuan mereka yang diturunkan dan sekalipun diketahui bagaimana orang pada umumnya berperilaku dalam situasi yang sama. Juga seseorang tidak dapat mengharapkan hasil yang sama dari orang dengan perkembangan usia dan intelektual yang sama. Dan akhirnya, perbedaan individual justru berarti karena perbedaan ini diperlukan bagi individulitas dalam pembentukan kepribadian(Fahyuni, 2018). Individualitas bukan hanya membuat orang menyenangkan, tetapi juga memungkinkan kemajuan sosial.

\section{E. Setiap Perkembangan Mempunyai Perilaku Karakteristik}

Setiap tahapan perkembangan mempunyai pola perilaku yang karakteristik. Pola-pola itu ditandai dengan periode equilibrium. Apabila individu dengan mudah menyesuaikan diri dengan tuntutan lingkungan dan akhirnya, berhasil mengadakan penyesuian pribadi dan penyesuian sosial yang baik. Pola-pola itu ditandai dengan periode disequilibrium, apabila mereka mengalami kesulitan dalam penyesuaian yang mengakibatkan penyesuian pribadi dan penyesuian sosial menjadi buruk. Sekalipun tidak perlu diragukan kebenarannya bahwa beberapa tahap perkembangan ke arah pendewasaan ditandai 
dengan perilaku yang lebih sulit dibandingakan dengan tahap-tahap lainnya. Tidak ada tahap dimana perilaku yang karakteristik itu tidak dianggap sebagai "perilaku yang sulit" dipandang dari standar dewasa. Hanya, apabila perilaku individu sejenis sejenis dengan usia tertentu dan dapat mengakibatkan penyesuian diri yang buruk, baru dinaggap sebagai perilaku yang sulit. Dalam kebanyakan contoh, perilaku demikian bersifat kekanak-kanakan dalam arti bahwa perilaku itu hanya dijumpai pada tingkat usia yang lebih muda.

Banyak bentuk perilaku yang sulit, yang tidak sesuai dengan tatanan masyarakat dan sukar dimengerti yang muncul pada saat-saat yang berbeda selama tahun-tahun perkembangan. Secara bertahap akan berkurang dan menghilang dan hanya diganti dengan bentuk perilaku lain yang sama sukarnya untuk dimengerti dan dihayati seperti bentuk perilaku yang telah menghilang itu. Akan tetapi, tidaklah aman untuk mengandaikan bahwa semua perilaku sulit itu akan hilang dengan bertambahnya usia anak. Apabila perilaku sulit itu berlangsung terus melampaui batas usia di mana perilaku itu biasanya terjadi, maka perilaku sulit itu menandakan bahwa kebutuhan pribadi maupun sosial individu tidak terpenuhi secara memuaskan.

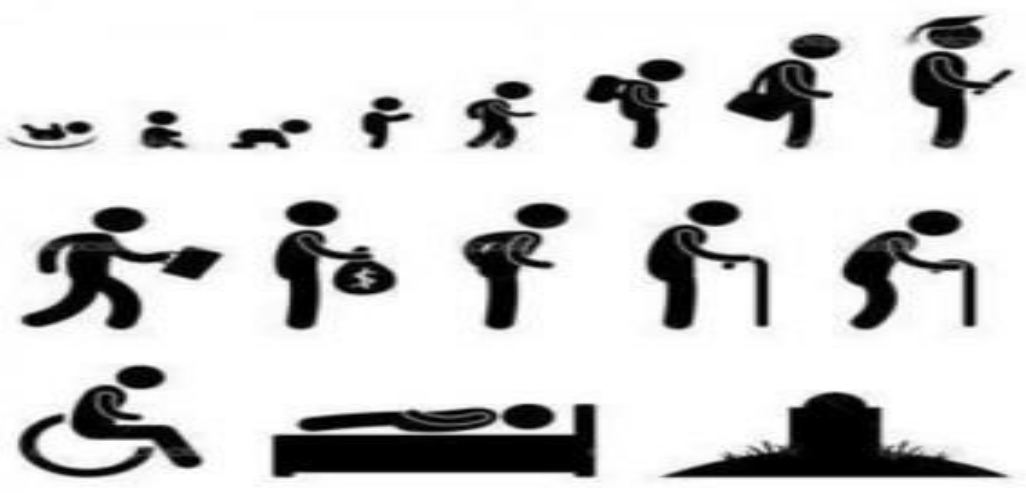

Gambar 3 Tingkatan Usia Selama Pertumbuhan 
Di semua tingkatan usia selama usia dewasa ada periode equilibrium dan dsiequilibrium, beberapa di antarannya berasal dari fisik, ada yang dari lingkungan atau perilaku khas dari tahap terdahulu yang terbawa. Misalnya, sikap ketergantungan yang kurang perlu dan sikap tidak berdaya yang ditampilkan oleh beberapa orang usia tua adalah sikap-sikap yang dibentuk di tahun-tahun kehidupan terdahulu yang masih terbawa. Dan disequilibrium emosional yang dialami oleh beberap orang wanita selama menopause merupakan cara-cara bereaksi yang kekanak-kanakan terhadap rasa kurang enaknya badan yang masih terbawa.

Anak-anak bertumbuh melalui beberapa tahap perkembangan yang dapat diprediksi dan tidak berbeda-beda. Dalam kasus ini, perubahan dapat agak mengganggu ketika anak-anak melangkah ke tahap perkembangan baru. Semua anak diyakin memeroleh kemampuan dalam urusan yang sama, walapun tingkan kemajuan berbeda dari anak ke anak. Kemampuan yang didapatkan anak-anak pada masing-masing tahap berikut bukan hanya "lebih sama"; pada masing-masing tahap, anak mengembangkan pemahaman, kemampuan, dan keyakinan yang berbeda-beda secara kualitatif. Melompati tahap adalah mustahil, walapun pada setiap titik tertentu anak yang sama dapat memperlihatkan perilaku yang merupakan karateristik lebih dari satu tahap (Zigler \& Gilman,1998). Berbeda dari teori berkelanjutan, teori perkembangan terputus (diskontinuous theoties of development) ini terputus pada faktor bawaan dari waktu ke waktu. Kondisi lingkungan mungkin saja mempunyai pengaruh terhadap kecepatan perkembangan, tetapi urutan tahap-tahap perkembangan pada dasarnya sudah tetap. 


\section{F. Setiap Tahap Perkembangan Mempunyai Risiko}

Setiap tahapan perkembangan mempunyai risiko. Ada bukti yang kuat bahwa setiap periode dalam rentang kehidupan dihubngkan dengan risiko perkembangan tertentu entah berasal dari fisik, psikologis atau lingkungan maupun masalah-masalah penyesuaian yang tak dapat dihindari. Risiko-risiko itu akan dibahas dalam bab-bab yang menyangkut berbagai tahap dalam pola perkembangan. Penting bagi mereka yangbertugas melatih anak-anak hendaknya sadar akan risiko yang biasanya terdapat pada setiap periode rentang kehidupan. Kesadaran demikian memungkinkan untuk mencegah atau mengurangi risiko tersebut. Demikian pula halnya dengan usia-usia berikutnya, khususnya usia pertengahan dan usia lanjut. Hal ini penting karena cara yang dipakai untuk mengatasi risiko ini mempunyai dampak yang besar terhadap penyesuian pribadi maupun penyesuian sosial mereka.

Perkembangan akan terjadi karena kematangan dan pengalaman-pengalaman dari lingkungan, masih banyak yang dapat dilakukan untuk membantu perkembangan seoptimal mungkin. Ini dapat dilakukan dengan merangsang perkembangan yang secara langsung mendorong individu untuk mempergunakan kemampuan yang terdapt dalam proses pengembangannya. Rangsangan ternyata paling efektif pada saat suatu kemampuan sedang berkembang secara normal, sekalipun di setiap saat juga penting. Pentingnya peran rangsangan bahkan telah ditunjukkan pada kasus anak-anak yang lahir prematur. Ditemukan bahwa perawat bayi-bayi prematur merangsang mereka dengan menggerakkan anggota tubuh, membalikkan ke posisi yang lain dan berbicara dengan mereka. Dan bayi-bayi prematur akan berkembang lebih cepat dari pada mereka yang tidak dirangsang, yang didiamkan dan ditelantarkan tanpa dipenuhi kebutuhan fisiknya sebagaimana biasanya dilakukan dirumah-rumah sakit di Amerika saat 
ini. Tingkat kematian pun lebih rendah dibandingkan dengan bayi-bayi prematur yang tidak dirangsang.

Semakin sering orang tua berbicara dengan anak-anak yang menjelang usia sekolah semakin cepat anak-anak ini belajar berbicara dan semakin kuat motivasi mereka untuk belajar berbicara. Sama halnya , rangsangan terhadap otot-otot selama tahun-tahun pertema menyebabakan kemampuan koordinasi motorik terjadi lebih cepat dan lebih baik(Wijirahayu, 2016). Penelitian terhadap usia lanjut mengungkapkan bahwa rangsangan dapat membantu mencegah kemunduran fisik dan mental. Mereka secara fisik dan mental tetap aktif pada usia tua tidak terlampau menunjukkan kemunduran fisik dan mental dibandingkan dengan mereka yang menganut "filsafat kursi goyang" terhadap masalah usia tua dan menjadi tidak aktif karena kemampuan-kemampuan fisik dan mental mereka sedikit sekali memperoleh rangsangan

Perkembangan dipengaruhi perubahan budaya, karena perkembangan individu dibentuk untuk menyesuaikan diri dengan standar-standar budaya dansegala hal yang ideal, maka perubahanperubahan dalam standar-standar tersebut akan memengaruhi pola perkembangan. Misalnya, di masa lalu standar pola perilaku anak lakilaki dalam banyak hal sangat berbeda dari standar perilaku yang dianggap tepat untuk anak perempuan. Orang tua dan guru mengetahui bahwa mereka diharapkan membentuk perilaku anakanak agar sesuai dengan standar yang berlaku. Sekarang ini, adanya beberapa orang dewasa yang lebih menyukai peran seks yang tradisional dan orang-orang lebih menyukai persamaan peran seks. Orang tua da guru sering kali tidak tahu pola budaya mana yang dipakai sebagai standar(Dwi Hastuti, 2016). Kalau orang-orang dewasa menentukan bahwa gaya hidup santai dan ceria lebih bermanfaat ketimbang sekedar penumpukan uang. Dan apabila nilai budaya 
seperti itu dapat diterima oleh kelompok sosial golongan mereka, maka gaya hidup demikian dengan jelas mempengaruhi pola perkembangan minat dan perilaku anak-anak mereka sepanjang kehidupannya. Anak-anak yang dibesarkan dalam keluarga dengan satu orang tua belajar menyesuaikan dengan standar perilaku yang dapat diterima secara budaya bagi keluarga seperti itu-standar yang dalam banyak hal berbeda dari standar yang berlaku dalam keluarga dengan dua oarng tua.

Harapan sosial untuk setiap tahap perkembangan. Setiap kelompok budaya mengharap anggotanya menguasai keterampilan tertentu yang penting dan memperoleh pola perilaku yang disetujui pada berbagai usia sepanjang rentan kehidupan. Havighurst menamakannya tugas-tugas dalam perkembangan. Menurut Havighurst, tugas perkembangan adalah "tugas yang muncul pada saat atau sekitar suatu periode tertentu dari kehidupan individu, yang kita berhasil akan menimbulkan rasa bahagia dan membawa ke arah keberhasilan dalam melaksanakan tugas-tugas berikutnya." Beberapa tugas terutama muncul sebagai akibat dari kematangan fisik, seperti belajar berjalan; yang lain terutama berkembang dari adanya tekanantekanan budaya dari masyarakat, seperti membaca; dan yang lain tumbuh dari nilai-nilai dan aspirasi-aspirasi individual, seperti memilih dan mempersiapkan suatu pekerjaan. Tetapi pada umumnya, tugastugas dalam perkembangan muncul dari ketiga macam kekuatan ini secara serempak.

Tugas-tugas dalam perkembangan mempunyai tiga macam tujuan yangsangat berguna. Pertama, sebagai petunjuk bagi individu untuk mengetahui apa yang diharapkan masyarakat dari mereka pada usia-usia tertentu. Misalnya, orang tua dapat dibimbing dalam mengajari anak-anak mereka yang masih kecil untuk mneguasai berbagai keterampilan. Dengan pengertian bahwa masyarakat 
mengharapkan anak-anak menguasai keterampilan-keterampilan tersebut pada usia-usia tertentu dan bahwa penyesuian diri mereka akan sangat dipengaruhi oleh seberapa jauh mereka berhasil melakukannya. Kedua, dalam memberi motivasi kepada setiap individu untuk malakukan apa yang diharapkan dari mereka oleh kelompok sosial pada usia tertentu sepanjang kehidupan mereka. Dan akhirnya, menunjukkan kepada setiap individu tentang apa yang akan mereka hadapi dan tindakan apa yang diharapkan dari mereka kalau sampai pada tingkat perkembangan berikutnya.

Piaget percaya bahwa anak dilahirkan dengan kecenderungan bawaan untuk berinteraksi dengan lingkungannya dan untuk memahaminya. Dia merujuk ke cara dasar mengorganisasikan dan mengolah informasi tersebut sebagai sturktur kognisi. Anak yang masih muda memperhatikan pola perilaku atau pemikiran, yang disebut skema, yang juga digunakan anak-anak yang lebih tua dan orang dewasa dalam berhadapan dengan objek di dunia ini. Kita menggunakan skema tersebut untuk mengetahui dunia ini dan bertindak di dalamnya; masing-masing skema memperlakukan semua objek dan peristiwa dengan cara yang sama. Msalnya, kebanyakan bayi yang masih kecil akan menemukan bahwa satu hal yang dapat dia lakukan dengan dengan objek itu adalah membantingnya. Ketika dia melakukannya, objek tadi menghasilkan suara dan dia melihat objek tersebut mengenai permukaan. Pengamatannya mengatakan sesuatu kepadanya tentang objek tersebut. Bayi juga belajar tentang objek dengan menggigitnya, mengisapnya, dan melemparnya. Masingmasing pendekatan untuk berinteraksi dengan objek ini ialah skema. Ketika bayi menemukan objek baru, bagaimana dia tahu apa sesungguhnya objek ini ? Menurut Piaget, dia akan menggunakan skema yang telah dia kembangkan dan akan mengetahui apakah objek tersebut menghasilkan suara keras atau lembut ketika dibanting, 
seperti apa rasanya, apakah objek tersebut menghasilkan susu, dan mungkin apakah objek itu menggelinding ataau hanya mengeluarkan suara kecil ketika dijatuhkan.

Penyesuian diri kepada situasi selalu sulit dan selalu disertai dengan bermacam-macam tingkat ketegangan emosional. Tetapi, sebagian besarkesulitandan ketegangan ini dapat dihilangkan kalu iindividu sadar akan apa yang akan terjadi kemudian dan secara bertahap mempersiapkan diri. Anak-anak yang menguasai keterampilan-keterampilan sosial, diperlukan untuk menghadapi kehidupan sosial remaja yang baru, akan lebih mudah menyesuaikan diri dengan lawan jenisnya bila mereka mencapai usia remaja, dan yang baru menginjak dewasa akan lebih mudah melewati masa peralihan ke masa usia pertengahan.dan tidak terlampau mengalami ketegangan kalau mereka secara bertahap menciptakan kegiatankegiatan waktu senggang dengan berkurangnya tanggung jawab sebagai orang tua.

Ada tiga macam bahaya potensial yang umum berhubungan dengan tugas-tugas dalam perkembangan. Pertama, harapan-harapan yang kurang tepat; baik individu sendiri maupun lingkungan sosial mengharapkan perilaku yang mungkin dalam perkembangan pada saat itu karena keterbatasan kemampuan fisik maupun psikologis. Bahaya potensial kedua adalah melangkahi tahap tertentu dalam perkembangan sebagai akibat kegagalan menguasahi tugas-tugas tertentu. Krisis yang dialami individu ketika melewati satu tingkatan ke tingkatan yang lain mengandung bahaya potensial ketiga yang umum yang muncul dari tugas-tugas itu sendiri. Sekalipun individu berhasil menguasahi tugas pada suatu tahap secara baik, namun keharusan menguasai sekelompok tugas-tugas baru yang tepat untuk tahap berikutnya pasti akan membawa ketegangan dan tekanan kondisikondisi yang dapat mengarah pada suatu krisis. Kesadaran inilah yang 
memengaruhi sikap dan perilaku mereka sendiri, demikian pula sikap orang lain terhadap mereka. 


\section{BAB II \\ MASA NEONATAL DAN PASCANATAL}

\section{A. Masa Bayi}

Masa bayi neonatal menurut kamus yang baku, merupakan permulaan atau peiode awal keberadaan sebagai individu dan bukan sebagai parasit di dalam tubuh ibu. Kamus juga merumuskan bayi sebagai seorang anak dalam kehidupannya yang pertama. Menurut hukum yang berlaku, bayi yang baru lahir merupakan individu yang belum dewasa sampai mencapai usia kematangan yang legal yang di Amerika saat ini mencapai usia delapan belas tahun. Menurut istilah medis, bayi adalah seorang anak yang muda usianya, tetapi tidak ditetapkan batasan usia berapa individu tidak lagi tergolong bayi dan menjadi seorang anak (Desmita,2009).

Setiap periode dalam rentang kehidupan ditandai oleh gejala perkembangan tertentu yang membedakannya dari periode-periode yang mendahuluinya atau yang mengikutinya. Ada beberapa gejala yang dapat dikaitkan dengan periode lain, tetapi ada yang muncul dalam bentuk yang berbeda selama masa bayi neonatal atau bayi yang baru lahir. Masa ini dimulai dari kelahiran dan berakhir pada saat bayi menjelang dua minggu. Periode yang tersingkat dari semua periode perkembangan yang ada. Periode ini adalah saat di mana janin harus menyesuaikan dengan kehidupan di luar rahim ibu, di mana ia telah hidup selama kurang lebih sembilan bulan.

Menurut kriteria medis, penyesuaian ini akan berakhir pada saat tali pusar lepas dari pusarnya. Menurut kriteria fisiologis berakhir pada saat bayi gemuk kembali setelah kehilangan berat badan sesudah dilahirkan. Menurut kriteria psikologis berakhir pada saat bayi mulai menunjukkan tanda-tanda kemajuan perkembangan perilaku. Sekalipun pada umumnya bayi menyelesaikan penyesuaian ini dalam dua minggu atau sedikit lebih cepat, tetapi bagi yang sulit lahir atau 
yang lahir sebelum waktunya memerlukan waktu penyesuaian yang lebih lama. Walaupun singkat tetapi masa bayi ini pada umumnya dibagi menjadi dua periode: periode pertunate dan periode neonate. Jarang jika ada janin yang keluar dari rahim ibu lebih dari empat puluh delapan jam, sekalipun pada persalinan yang sulit sebaliknya, diperlukan waktu sekitar dua minggu untuk menyesuaikan dengan lingkungan baru di luar tubuh ibu.

\section{PEMBAGIAN MASA BAYI NEONATAL}

Periode Partunate (mulai saat kelahiran sampai antara lima belas dan tiga puluh menit sesudah kelahiran). Periode ini bermula dari keluarnya janin dari rahim ibu dan berakhir setelah tali pusar dipotong dan diikat. Sampai hal ini selesai dilakukan, bayi masih merupakan pascamatur, yaitu lingkungan di luar tubuh ibu.

Periode Neonate (dari pemotongan dan pengikatan talipusar sampai sekitar akhir minggu kedua dari kehidupan pascamatur). Sekarang bayi adalah individu yang terpisah, mandiri dan tidak lagi merupakan parasit. Selama periode ini bayi harus mengadakan penyesuaian pada lingkungan baru di luar tubuh ibunya. 


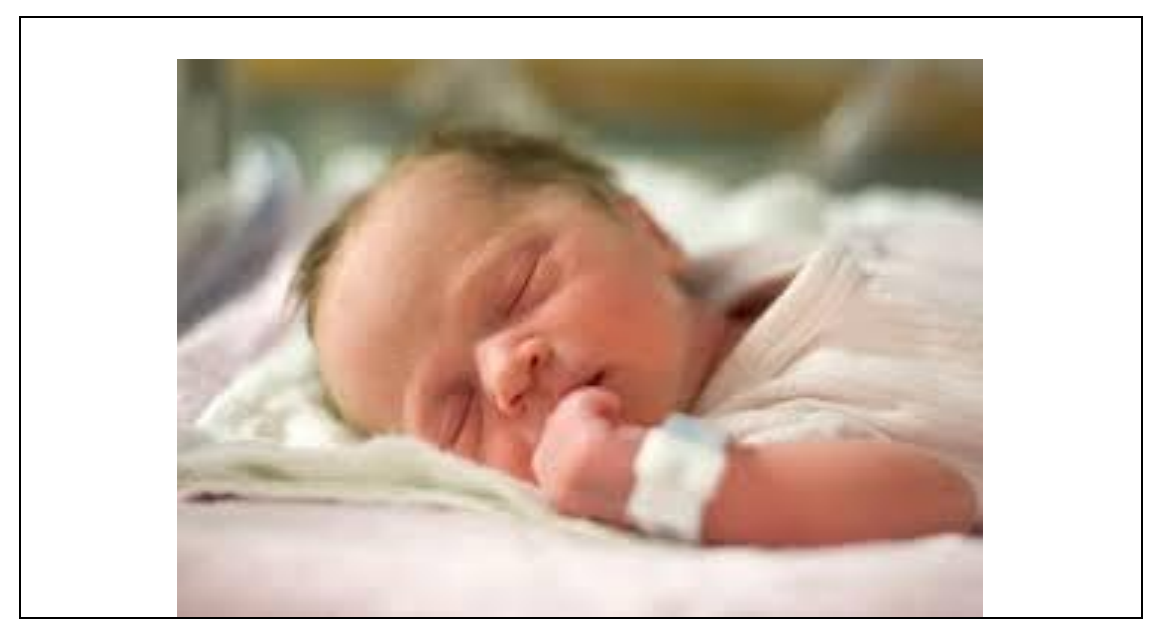

Meskipun rentang kehidupan manusia secara resmi dimulai pada saat kelahiran, kelahiran merupkan suatu gangguan pada pola perkembangan yang dimulai pada saat pembuahan. Ini adalah suatu peralihan dari lingkungan dalam ke lingkungan luar. Seperti halnya semua peralihan, diperlukan penyesuaian diri bayi. Bagi beberapa bayi penyesuaian mudah dilakukan, namun beberapa bayi lain terasa sulit dan mengalami kegagalan. Miller mengatakan "Dalam seluruh kehidupannya, tidak pernah terjadi perubahan lokasi yang sangat tibatiba dan sangat menyeluruh". 


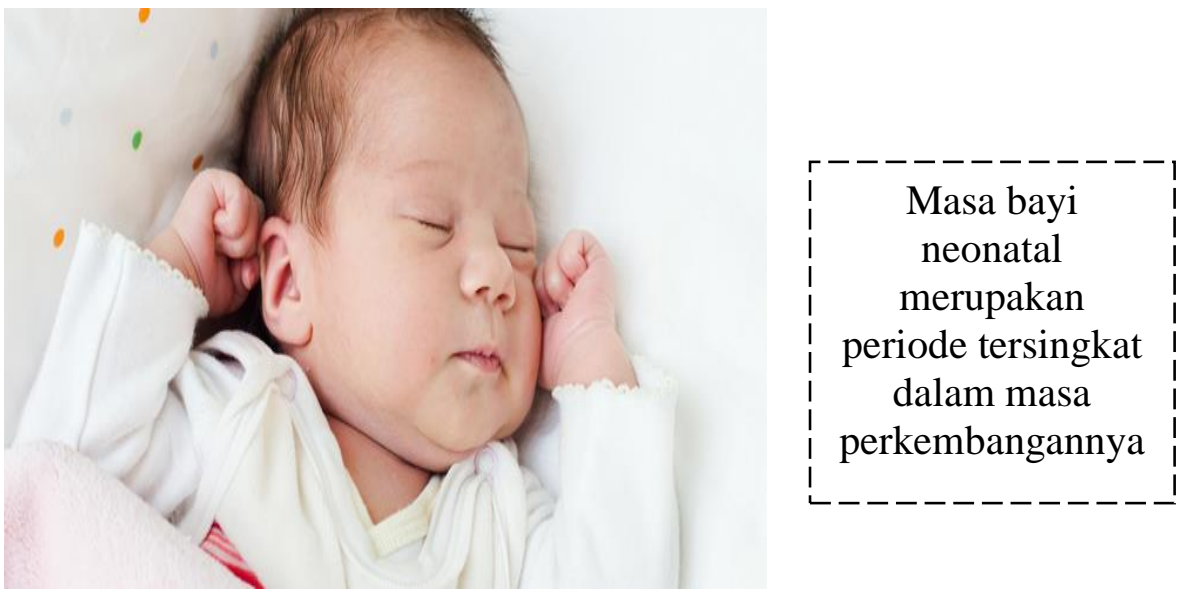

Gambar 4. Masa Bayi Neonatal

\section{Masa Neonatal Merupakan Masa Terhentinya Perkembangan}

Pertumbuhan dan perkembangan pesat yang terjadi selama periode pranatal tiba-tiba terhenti pada kelahiran. Kenyataannya seringkali terjadi sedikit kemunduran, seperti berkurangnya berat badan dan kecenderungan menjadi kurang sehat dibandingkan dengan pada saat dilahirkan. Biasanya kemunduran yang sedikit ini berlangsung beberapa hari sampai seminggu, dan setelah itu bayi mulai meningkat lagi. Pada akhir periode bayi, keadaan perkembangan bayi kembali biasa seperti keadaan pada waktu ia dilahirkan. Terhentinya pertumbuhan dan perkembangan yang merupakan ciri dari periode ini, disebabkan oleh pentingnya melakukan perkembangan yang radikal pada lingkungan pascanatal. Sekali penyesuaian ini terjadi, bayi kembali melanjutkan pertumbuhan dan perkembangan. Meskipun terhentinya perkembangan dalam periode ini merupakan hal yang normal, tetapi banyak orang tua, terutama yang baru pertam kali mempunyai anak, menjadi khawatir dan takut 
kalau-kalau ada yang salah pada anak mereka. Akibatnya, terhentinya perkembangan ini dapat menjadi bahaya fisik.

Piaget percaya semua anak dilahirkan dengan kecenderungan bawaan untuk berinteraksi dengan lingkungan mereka dan untuk memahaminya. Perubahan dramatis terjadi ketika bayi melewati periode sensorimotor. Pada awalnya, semua bayi mempunyai perilaku bawaan yang disebut gerakan reflek (reflex). Sentuhlah bibir anak yang baru lahir, dan bayi itu pun akan mulai menghisap; letakkan jari Anda ke telapak tangan bayi, dan bayi itu pun akan menggenggamnya. Perilaku ini dan perilaku lain adalah bawaan dan merupakan landasan yang menjadi dasar pembentukan skema pertama bayi tersebut.

Bayi segara belajar menggunakan gerakan reflek ini untuk mengahsilkan pola perilaku yang lebih menarik dan intensional. Pembelajaran ini pada awalnya terjadi secara kebetulan dan kemudian melalui upaya uji-coba yang lebih intensional. Menurut Piaget, pad akhir tahap sensorimotor, anak-anak telah beranjak dari pendekatan pemecahan masalah yang sebelumnya bersifat uji-coba ke pendekatan yang lebih terencana.untuk pertama kali mereka dapat melambangkan objek dan peristiwa ke dalam pikiran. Sekarang muncul apa yang disebut "pemikiran" oleh kebanyakan di antara kita. Ini adalah kemajuan besar karena hal itu berarti anak tersebut dapat memikirkan dan merencanakan perilaku. Misalnya, andaikan anak yang berusia 2 tahun ada di dapur sedang mengamati ibunya menyiapkan makan malam. Apabila anak itu tahu di mana bangku pijakan disimpan, mungkin dia akan memintanya dipasang untuk dapat melihat meja dengan lebih jelas dan untuk memeroleh kesempatan yang lebih baik untuk menggigit makanan. 


\section{Masa Neonatal Pendahuluan dari Perkembangan Selanjutnya}

Tidak ada kemungkinan untuk meramalkan secara tepat bagaimana perkembangan individu di masa depan berdasarkan perkembangan yang tampak pada waktu dilahirkan (Hurlock, 1980). Tetapi, perkembangan bayi yang baru lahir dapat memberi petunjuk tentang apa yang dapt diharapkan akan terjadi seperti yang di katakan oleh Bell dkk:

"Perilaku bayi neonatal lebih menyerupai kata pendahuluan sebuah buku daripada sebuah meja yang isinya bulum ditemukan. Selanjutnya pendahuluan itu sendiri hanyalah suatu garis besar yang memerlukan perbaikan yang cepat. Terdapat beberapa petunjuk mengenai sifat buku di dalam pendahuluan tetapi hanya dalam bentuk kode dan memandang petunjuk itu sebagai ramalan cenderung akan mengecewakan".

\section{Masa Bayi Neonatal Merupakan Periode yang Berbahaya}

Masa bayi neonatal merupakan periode yang berbahaya, baik secara fisik maupun psikologis. Secara fisik periode ini berbahaya karena sulitnya mengadakan penyesuaian diri secara radikal yang penting pada lingkungan yang sagat baru dan sangat berbeda. Hal ini terbukti dengan tingginya tingkat kematian. Secara psikologis, masa bayi merupakan saat terbentuknya sikap dari orang-orang yang berarti bagi bayi. Kebanyakan sikap yang terbentuk sepanjang periode pranatal dan mungkin berubah secara radikal setelah bayi dilahirkan, tetapi beberapa di antaranya relatif menetap atau semakin kuat bergantung pada kondisi pada saat kelahiran dan pada mudah atau sulitnya penyesuaian antara bayi dan orang tua.

Bayi neonatal harus melakukan empat penyesuaian pokok sebelum mereka dapat melanjutkan kemajuan perkembangan mereka. Kalau penyesuaian ini tidak segera dilakukan, kehidupan mereka akan terancam. Selama penyesuaian ini, tidak terjadi kemajuan 
perkembangan, malahan perkembangannya terhenti atau bahkan mundur ke tahap perkembangan yang lebih rendah. Penyesuaian ini diuraikan dalam kotak dibawah ini.

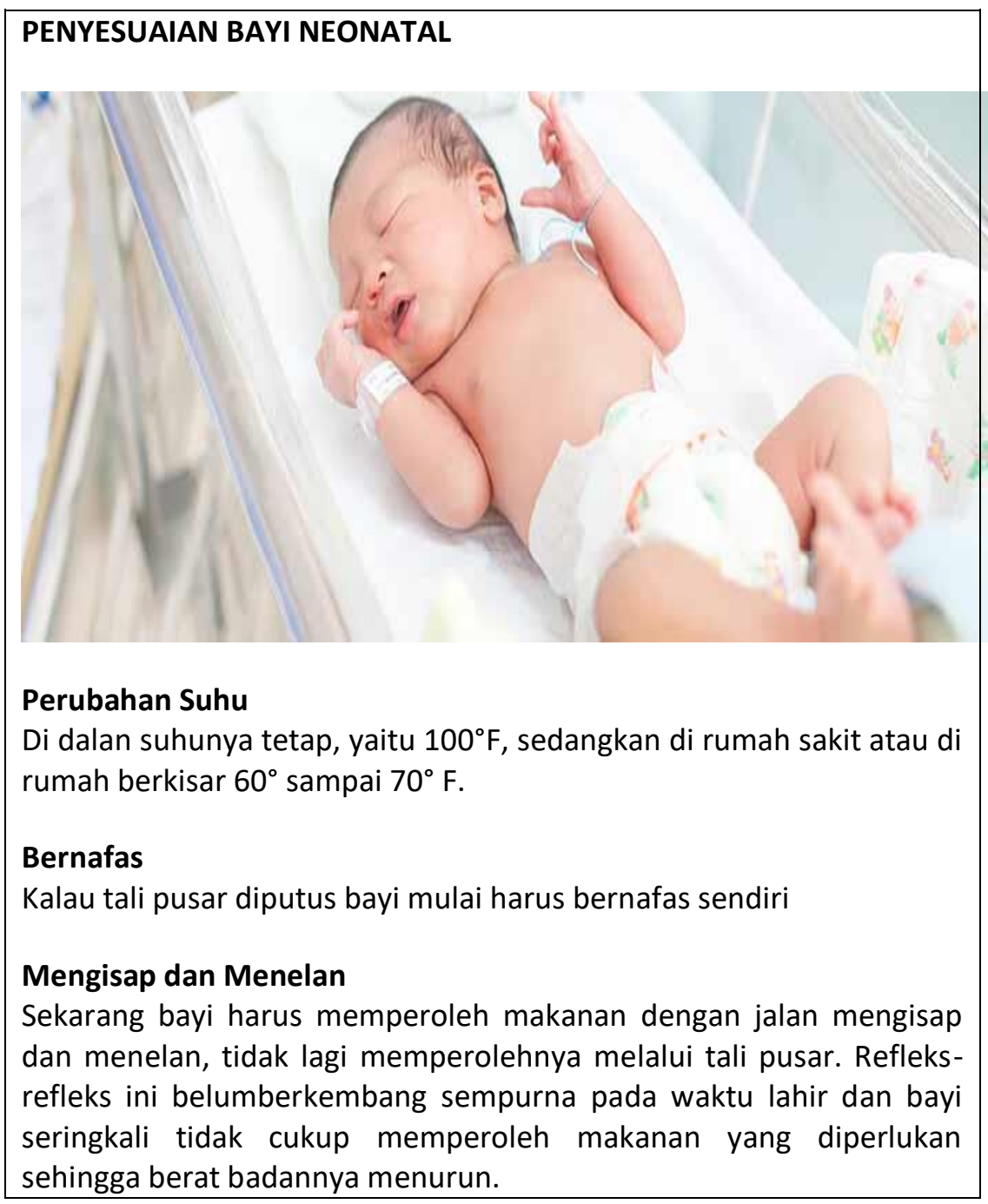




\section{Pembuangan}

Alat-alat pembuangan bayi mulai berfungsi segera setelah dilahirkan; sebelumnya pembuangan dilakukan melalui tali pusar.

Pada mulanya semua bayi mengalami kesulitan dalam menyesuaikan diri dengan kehidupan pascanatal. Beberapa mungkin mengalami kesulitan dalam penyesuaian dengan perubahan suhu dan menderita salesma yang dapat berkembang menjadi pneumonia. Bayi yang lain mengalami kesulitan dalam bernafas dan harus diberi oksigen. Kebanyakan bayi tercekik pada saat mencoba menghisap dan menelan, dan banyak yang sering muntah sehingga kurang memperoleh makanan yang diperlukan untuk pertumbuhan atau tidak dapat mempertahankan berat badan mereka. Tidak banyak yang mengalami kesulitan dalam pembuangan air besar.

\section{B. Penyesuaian Pada Kehidupan Pascanatal}

Banyak kondisi yang memengaruhi keberhasilan bayi untuk menyesuaikan diri dengan kehidupan pascanatal. Kondisi terpenting antara lain, seperti yang ditunjukkan oleh hasil riset, jenis lingkungan pranatal, jenis persalinan dan pengalaman-pengalaman yang berkaitan dengan persalinan, lamanya periode kehamilan, sikap-sikap orang tua dan perawatan pascanatal. Kondisi pertama yang memengaruhi jenis penyesuaian diri yang dilakukan bayi pada kehidupan pascanatal adalah jenis lingkungan pranatal yang dialaminya. Lingkungan pranatal yang sehat akan memberi penyesuaian diri yang baik pada kehidupan pascanatal. Di lain pihak, terdapat banyak macam gangguan di dalam rahim yang dapat dan sering menyebabkan bayi terpaksa lahir dan kemudian menjadi penyebab penderitaan hidup". Perawatan ibu yang kurang baik selama kehamilan yang disebabkan karena kemiskinan atau acuh tak acuh seringkali menyebabkan kondisi-kondisi yang 
kurang menyenangkan berkembang di dalam lingkungan dalam rahim yang mempengaruhi perkembangan anak(Desmita,2009)..

Kekurangan gizi pada ibu selama kehamilan ternyata menyebabkan kelahiran prematur, mati pada waktu dilahirkan, atau pada hari-hari pertama setelah lahir. Bayi yang ibunya menderita penyakit diabetes lebih banyak mengalami kesulitan dalam penyesuaian dan tingkat kematian lebih tinggi daripada bayi yang ibunya sehat.

Salah satu kondisi yang menimbulkan kesulitan dalam penyesuaian diri pascanatal adalah lingkungan pranatal yang ditandai oleh tekanan kuat yang dialami ibunya dan dalam jangka waktu yang lama. Seperti telah disebutkan diatas hal ini mengakibatkan komplikasi selama kehamilan dan persalinan. Tekanan yang dialami ibu juga menyebabkan janin menjadi hiperaktif selama bulan-bulan terakhir kehamilanj dam kondisi ini cenderung mapan setelah lahir, yang gejalanya tampak dalam kesulitan makan, gagal menambah berat badan, sulit tidur, peka, cepat terganggu dan sejumlah kondisi-kondisi lain yang membuat penyesuaian pada kehidupan pascanatal menjadi sulit.

\section{INDIKASI KESULITAN PENYESUAIAN TERHADAP KEHIDUPAN PASCANATAL}

\section{Berkurangnya Berat Badan}

Karena adanya kesulitan untuk mengisap dan menelan, bayi yang baru lahir biasanya mengalami penurunan berat badan dalam menggu pertama.

\section{Perilaku yang Tidak Teratur}

Pada hari pertama atau kedua hidup pascanatal, semua bayi menunjukkan perilaku yang relatif tidak teratur, seperti 
ketidakteraturan dalam bernafas, sering kencing dan berak, berdesah dan muntah. Hal ini sebagian disebabkan karena adanya tekanan pada otak selama persalinan yang mengakibatkan keadaan pingsan dan sebagian karena keadaan susunan saraf otonom yang kurang berkembang, yang mengendalikan keseimbangan tubuh.

\section{Kematian Bayi}

Bahkan hingga sekarang ini, tingkat kematian bayi selama dua hari pertama pascanatal cenderung tinggi. Kematian itu disebabkan banyak faktor yang berbeda.

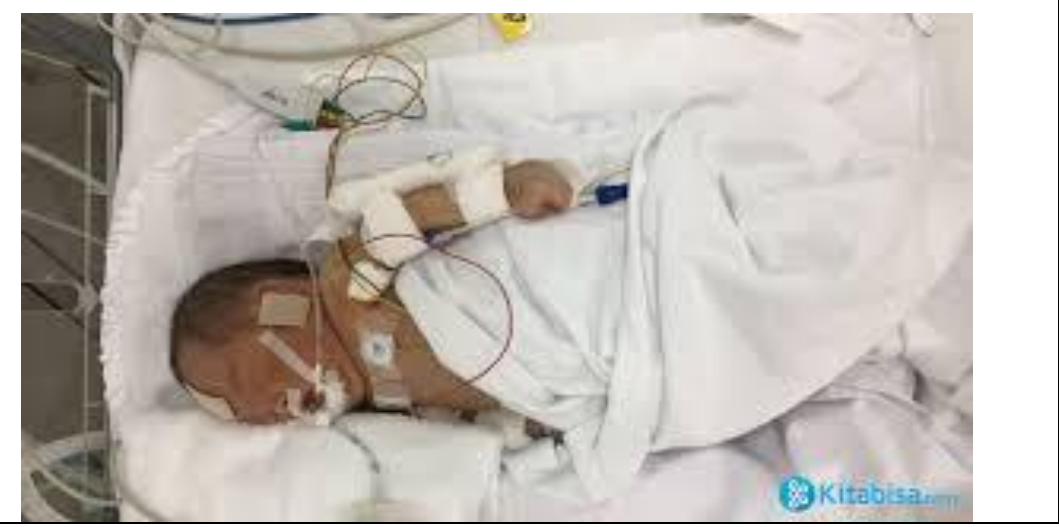

\section{Jenis Persalinan}

Kondisi yang mempengaruhi jenis penyesuaian diri pada masa pascanatal adalah jenis persalinan yang dialami bayi. Sampai sekarang kepercayaan tradisional tentang hal ini dan apa efeknya pada penyesuaian individu dalam kehidupan masih banyak dianut orang. Misalnya, banyak kepercayaan yang berkisar tentang baik tidaknya waktu kelahiran. Juga ada kepercayaan bahwa mudah atau sulitnya persalinan memengaruhi penyesuaian pascanatal dan kepercayaan bahwa bayi yang lahir sebelum waktunya tidak akan sekuat bayi yang 
cukup bulan atau penyesuaian tidak seberhasil penyesuaian bayi cukup bulan.

Sekalipun teknologi medis yang canggih dipakai, persalinan tetap merupakan pegalaman yang berbahaya. Jeffcoate menunjukkan bahwa "perjalanan yang paling berbahaya yang dialami tiap calon bayi adalah saluran lahir empat inci".

\section{JENIS - JENIS PERSALINAN

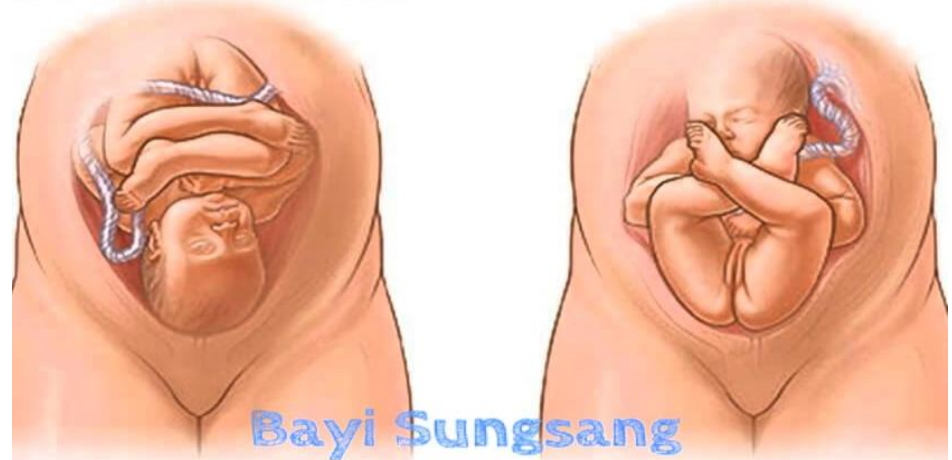 \\ Normal \\ Frank breech \\ Alamiah atau Spontan \\ Dalam persalinan alamiah, posisi dan besarnya janin dalam hubungannya dengan alat-alat reproduksi ibu mempermudah bayi lahir secara normal, dengan posisi kepala di bawah. \\ Sungsang \\ Dalam perslinan sungsang, bokong keluar lebih dulu disusul oleh kaki dan akhirnya baru kepala. \\ Alat \\ Kalau janin terlampau besar sehingga tidak dapat keluar secara spontan atau kalau posisinya sedemikian rupa sehingga tidak memungkinkan persalinan normal, harus dipergunakan alat untuk membantu persalinan. \\ Pembedahan caesar \\ Kalau hasil pemotretan sinar $x$ yang dilakukan pada akhir masa kehamilan menunjukkan bahwa akan terjadi komplikasi bila bayi}




\section{Melintang}

Posisi janin melintang dalam rahim ibu. Dalam hal ini harus dipergunakan alat-alat untuk persalinan kecuali kalau posisi janin dapat berubah sebelum proses kelahiran mulai keluar melalui saluran lahir, maka bayi harus dikeluarkan dari rahim ibu melalui pembedahan dinding perut ibu.

Bayi yang dilahirkan secara spontan biasanya lebih cepat dan lebih berhasil menyesuaikan diri pad lingkungan pascanatal daripada bayi yang kelahirannya cukup sulit sehingga harus menggunakan alat atau pembedahan caesar. Terdapat lebih banyak bahaya yang dihubungkan dengan persalinan dengan alat dan bedah caesar dibandingkan dengan persalinan spontan. Semakin sulit persalinan semakin besar kemungkinan terjadinya kerusakan dan semakin parah kerusakan yang terjadi. Wanita yang badannya kecil relatif lebih banyak melahirkan bayi mati dibandingkan wanita yang berbadan besar, seringkali karena harus menggunakan alat untuk membantu persalinan. Ketidakmampuan motorik, kelumpuhan, cerebral palsy dan keterbelakangan mental seringkali dilaporkan sebagai akibat buruk dari persalinan yang sulit, terutama bila harus digunakan sarana medis.

\section{Bahaya Pada Bayi Neonatal}

Meskipun periode ini singkat, namun periode bayi neonatal merupakan salah satu dari periode yang paling berbahaya dalam rentang kehidupan. Bahaya dalam periode ini mungkin berbentuk fisik, psikologis, atu kedua-duanya, dan dapat mempengaruhi penyesuaian diri saat ini dan masa depan. Dalam ahl masa terhentinya perkembangan penyesuaian fisik berlangsung sangat lambat sehingga mengancam kehidupan bayi. Secara psikologis, masa 
terhentinyaperkembangan berbahaya karena dapat menyebabkan orang tua menjadi cemas dan takut tentang perkembangan anak, perasaan-perasaan yang dapat tetap ada dan mengakibatkan sikap yang sangat melindungi di tahun-tahun kemudian (Hamzah, 2006).

Beberapa bahaya fisik dapat bersifat sementara sedangkan beberapa lainnya dapat mempengaruhi seluruh pola kehidupan individu, diantaranya.

\section{Lingkungan Pranatal yang Tidak Baik}

Sebagai akibat kondisi lingkungan yang tidak baik, bayi akan mengalami kesulitan dalam menyesuaikan dengan kehidupan pascanatal. Ibu yang terlampau banyak merokok, misalnya, dapat mempengaruhi perkembangan janin. Faktor penting lain yang menyebabkan bayi menjadi tegang dan gelisah adalah tekanan berat yang dialami ibu dalam waktu yang lama.

\section{Persalinan yang Sulit dan Ruwet}

Seperti telah ditekankan sebelumnya, persalinan yang sulit atau ruwet seringkali mengakibatkan kerusakan otak sementara atau seterusnya. Kalau persalinan harus menggunakan alt-alat, misalnya bila janin terlampau besar sehingga harus dibantu untuk turun ke dalam saluran persalinan atau letak bayi sungsang atau melintang, selalu terdapat kemungkinan terjadinya kerusakan otak sebagai akibat penggunaan alat. Pembedahan caesar atau kelahiran yang dipercepat dapat menyebabkan ancxia, hilangnya oksigen untuk otak yang bersifat sementara. Kalau anoxia sangat hebat, maka kerusakan otak akan jauh lebih besar daripada kalau anoxia hanya berlangsung beberapa detik. Semakin ruwet persalinan dan semakin banyak kerusakan pada jaringan otak, maka efeknya pada penyesuaian diri bayi dan kehidupan pascanatal akan semakin besar. Kerusakan otak yang hebat dan 
mapan akan memberikan efek buruk pada semua penyesuaian selama masa bayi dan seringkali selama masa kanak-kanak atau bahkan seluruh hidupnya. Efek kerusakan otak sangat sering tampak dalam perilaku yang tidak terkoordinasi, hiperaktivitas, kesulitan belajar dan masalah emosional.

\section{Kelahiran Kembar}

Bayi kembar biasanya lebih kecil dan lebih lemah daripada bayi tunggal, karena keadaan penuh sesak dalam periode pranatal menghambat gerakan janin. Bayi ini cendrung lahir sebelum waktunya dan menambah permasalahan dalam penyesuaian diri.

\section{Postmatur}

Kelahiran postmatur (pascamatur) berbahaya hanya apabila janin menjadi begitu besar sehingga memerlukan penggunaan alat bantu atau pembedahan, di mana bahaya lebih disebabkan karena kondisi yang berkaitan dengan persalinan dan tidak semata-mata karena keadaan lewat umur. Satu penelitian tentang bayi yang dilahirkan lebih dari tiga minggu dari seharusnya mereka mengalami masalah dalam penyesuaian neonatal dan penyesuaian sosial sangat buruk dan memerlukan pendidikan khusus pada usia tujuh tahun.

\section{Prematur}

Keadaan belum cukup umur menyebabkan lebih banyak kematian daripada kondisi lain. Ini akan dibahas secara lebih rinci dalam bagian yang mengupas masalah kematian bayi. Bayi prematur juga mudah mengalami kerusakan otak karena tengkorak kepala belum cukup berkembang untuk melindungi otak dari tekanantekanan yang dialami selama persalinan. Masalah umum lainnya adalah anoxia karena mekanisme pernapasan belum sepenuhnya berkembang. 
Masalah yang harus dihadapi oleh semua bayi neonatal terdapat lebih banyak pada bayi preamtur. Misalnya, mereka membutuhkan oksigen tiga kali lebih banyak dibandingkan bayi yang cukup umur karena pernapasannya ditandai sentakan-sentakan dan keterengahengahan. Seringkali ia mengalami kesulitan dalam mengembangkan paru-paru, dan lemahnya otot-otot membuat sulit bernapas. Belum cukupnya umur mempengaruhi penyesuaian diri tidak saja selama bayi tetapi juga pada tahun-tahun selanjutnya. 
BAHAYA PADA BAYI NEONATAL

Perkembangan Fisik dan Kesehatan

Bayi prematur biasanya labih kecil daripada bayi yang dilahirkan cukup umur, dan biasanya cenderung tetap lebih kecil daripada teman-teman sebayana sekalipun sudah mencapai tahap pubertas di mana perkembangan biasanya sangat meningkat. Selama tahun pertama bayi prematur lebih banyak mengalami sakit, dan menderita panyakit yang lebih parah dibandingkan dengan bayi cukup umur, kecenderungan "sakitsakitan" menetap sampai masa kanak-kanak. Mereka sering mengalami cacat fisik, terutama cacat mata akibat anoxia, yaitu masalah yang umum pada kelahiran bayi prematur.

\section{Kelambatan Perkembangan}

Sampai usia dua atau tiga tahun mereka sering mengalami kelambatan dalam perkembangan dibandingkan dengan bayi yang cukup umur. Misalnya, mereka sering terlambat duduk, berdiri, dan berbicara.

\section{Perilaku Sensorik}

Bayi prematur sangat peka terhadap semua bentuk suara,
Inteligensi

Sebagai kelompok, anak yang prematur mempunyai nilai IQ yang lebih rendah daripada anak yang dilahirkan dengan cukup umur, dan ia mengalami cacat mental yang lebih parah karena luka otak. Nilai tes membaca dan berhitung cenderung lebih rendah dan kelasnya berada di bawah anak normal.

\section{Sosialisasi}

Penyesuaian sosial anak prematur cenderung buruk dibandingkan anak yang cukup umur. Keadaan ini berlangsung terus sampai masa remaja dan sebagian disebabkan sikap orang tua yang sangat melindungi. Mereka juga menunjukkan lebih banyak perilaku yang mengundang masalah pada setiap tahap usia.

\section{Perilaku Emosional}

Beberapa anak prematur cenderung bersikap apatis secara emosional, tetapi lebih sering lagi menjadi pemarah, mudah tersinggung, dan bersikap negatif. Kekacauanemosional, sebagaimana sifat-sifat nervous, seperti mudah marah, berang, meledak, dan mengisap jempol, adalah lazim.

\section{Perilaku Menyimpang}

Ketika bayi yang menderita kerusakan otak pada saat dilahirkan bertambah besar, mereka menunjukkan perilaku 
terhadap warna dan objek menyimpang, seperti cenderung yangbergerak. Karena itu, pada mangalami kecelakaan, gerak-gerik saat bertambah besar ia lebih yang gelisah dan hiperkinetik, terganggu daripada bayi cukup perilaku yang tidak teratur. Kalau umur.

\section{Pengendalian Motorik}

Bayi prematur sering kali janggal dan mempunyai sikap tubuh yang buruk. Sering terjadi cerebral palsy sebagai akibat dari kerusakan otak.

\section{Perkembangan Bicara}

Perkembangan bicara pada bayi prematur lebih lambat daripada bayi yang cukup umur. Ocehocehan bayi bertahan lebih lama dan ia lebih banyak mengalami cacat dalam bicara, terutama bicara gagap. Bayi prematur juga cenderung memiliki kosa kata lebih sedikit dan melakukanbanyak kesalahan dalam menyusun struktur kalimat. kerusakan otak hanya ringan dan bersifat sementara, mereka dapat menunjukkan penyimpangan perilaku, terutama perilaku yang kurang matang dan mementingkan diri sendiri. Hal ini terutama karena mereka terlampau dilindungi oleh orang tua yang selalu khawatir. 
Sikap seorang ibu sangatlah penting karena secara langsung mempengaruhi perawatan bayi. Moss mengatakan, "lamanya bayi terjaga dan menangis merupakan suatu kekuatan yang mengubah cara perawatan ibu karena keadaan juga dan menangis cenderung memerlukan lebih banyak pengawasan dan hubungan dengan ibu" (Desmita,2009).. Jadi, perilaku bayi mempengaruhi perilaku ibu, kalau hal ini dimulai dengan sikap yang kurang menyenangkan maka sikap ini akan semakin meningkat sehingga masalah-masalah dalam penyesuaian bayi memburuk.

Pentingnya sikap ayah, saudara-saudara kandung, nenek, dan keluarga lainnya bukan karena adanya pengaruh yang langsung melainkan karenasikap itu cenderung menetap sampai setelah periode bayi baru lahir ketika hubungan dengan anak meningkat. Hal ini berlaku bagi sikap ayah dan saudara-saudara kandung. Meskipun setiap bayi neonatal dapat dianggap kurang menyenangkan oleh orang-orang yang berarti, tetapi sasaran yang paling banyak dikenal sikap-sikap itu adalah anak pertama, mereka yang mengalami kerusakan pada waktu lahir, bayi prematur dan bayi kemabar. Terhadap bayi yang dilahirkan berikutnya orang tua lebih bersikap realistik terhadap harapan dan pengaharapan mereka dan menerima bayi secara lebih filosofis. Dalam hal bayi prematur dan bayi kembar, kepercayaan tradisional cenderung menimbulkan sikap yang kurang menyenangkan. 


\section{BAB III \\ MASA KANAK-KANAK}

\section{A. Perkembangan Masa Kanak-Kanak}

Anak merupakan individu yang unik, sebagai seorang individu yang unik dan perlu mendapatkan perhatian dari segala aspek kehidupannya. Perkembangan merupakan perubahan yang dimulai dari sejak pembuahan dan terus berlanjut pada perkembangan setiap individu. Perkembangan ini dapat dilihat dari kematangan yang ditampilkan oleh anak maupun kemampuan proses belajar yang dialami oleh anak. Proses perkembangan dimulai dari hal-hal yang sederhana dari sekeliling anak yang berkembang menjadi semakin kompleks.

Pada umumnya orang berpendapat bahwa masa kanak-kanak merupakan masa yang terpanjang dalam rentang kehidupan. Saat di mana perkembangan individu relatif tidak berdaya dan bergantung pada orang lain. Bagi kebanyakan anak (young children) dalam uraian selanjutnya digunakan kata "anak-anak" menunjuk pada pengertian anak yang masih kanak-kanak yakni masa yang seringkali dianggap tidak ada akhirnya sewaktu mereka tidak sabar menunggu saat yang didambakan yakni pengakuan dari masyarakat bahwa mereka bukan anak-anak lagi melainkan "orang-orang dewasa." Menurut urutan waktu, masa kanak-kanak adalah masa perkembangan dari usia 2 hingga 6 tahun. Perkembangan fisik merupakan dasar bagi kemajuan perkembangan berikutnya, dengan meningkatnya pertumbuhan berat badan maupun tinggi badan serta kekuatannya untuk anak lebih aktif dan berkembang fisiknya, dan juga eksplorasi terhadap lingkungan tanpa bantuan orang tuanya (Murni, 2017).

Masa kanak-kanak dimulai setelah melewati masa bayi yang penuh ketergantungan, yakni kira-kira usia dua tahun sampai saat anak matang secara seksual, kira-kira tiga belas tahun untuk wanita 
dan empat belas tahun untuk pria. Setelah anak matang secara seksual, maka ia disebut remaja. Selama periode yang panjang ini secara kasar sebelas tahun wanita dan dua belas tahun untuk pria terjadilah sejumlah perubahan yang mencolok baik secara pisik maupun psikologis. Karena tekanan budaya dan harapan untuk menguasai hal-hal tertentu pada usia tertentu itu berbeda daripada usia yang lain, maka anak pada awal masa kanak-kanak agak berbeda dengan anak pada akhir periode ini. Keberhasilan pada masa kanakkanak menjadi landasan bagi keberhasilan pendidikan seseorang pada jenjang berikutnya. Usia dini disebut sebagai golden age atau usia emas, artinya apabila seorang anak mendapatkan pendidikan yang tepat, maka ia akan memiliki kesiapan belajar yang baik sebagai salah satu kunci utama keberhasilan belajar pada jenjang berikutnya (Hastuti, 2016)

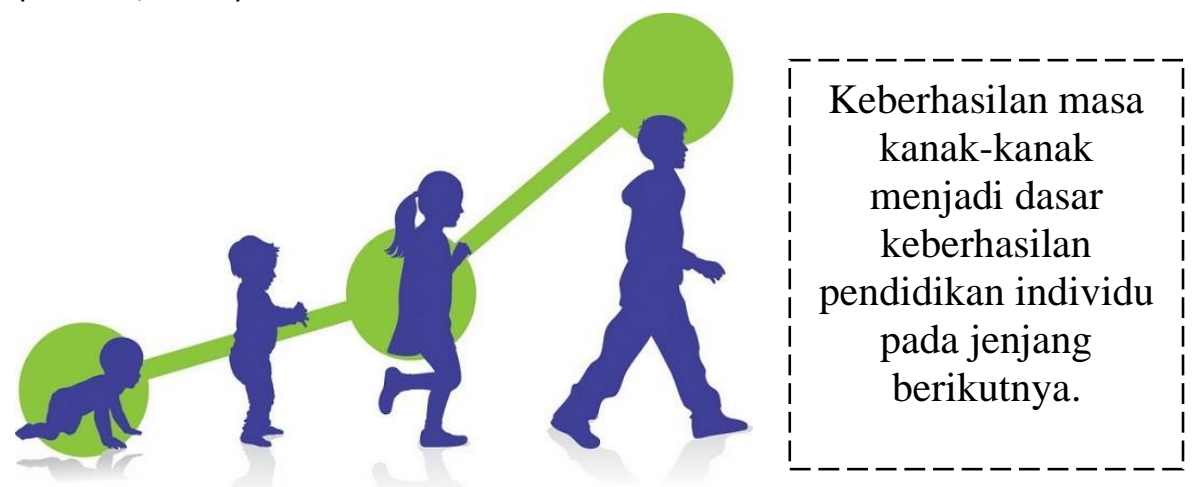

Gambar 5. Periodesasi Perkembangan Manusia

Pada saat ini, secara luas diketahui bahwa masa kanak-kanak harus dibagi menjadi dua periode yang berbeda awal dan akhir masa kanak-kanak. Periode awal berlangsung dari umur dua sampai enam tahun dan periode akhir dari enam sampai tiba saatnya anak matang secara seksual. Dengan demikian awal masa kanak-kanak dimulai 
sebagai penutup masa bayi-usia di mana ketergantungan tumbuhnya kemandirian dan berakhir di sekitar usia masuk sekolah dasar. Garis pemisah antara awal dan akhir masa kanak-kanak penting karena dua alasan berikut. Pertama, pemisahan ini khususnya digunakan untuk anak-anak yang sebelum mancapai usia wajib belajar diperlakukan sangat berbeda dari anak yang sudah masuk sekolah. Perlakuan yang diterima anak-anak dan harapan kelompok sosial yang mempengaruhi perlakuan apa yang akan diberikan menentukan di mana garis pemisah itu harus ditegaskan. Alasan kedua mengapa begitu penting garis pemisah antara awal dan akhir masa kanak-kanak pada usia enam tahun itu adalah efek dari faktor-faktor sosial, bukan oleh faktor-faktor fisik. Relatif hanya terdapat sedikit perbedaan dalam pertumbuhan dan perkembangan pisik anak-anak antara sebelum dan sesudah usia enam tahun. Misalnya anak-anak usia lima tahun tidak berbeda secara nyata dari mereka yang berusia tujuh tahun.

Myers (1992) mendefinisikan perkembangan anak sebagai proses perubahan pada anak untuk belajar pada tingkatan yang lebih kompleks dalam berpikir, bergerak, berperasaan dan berhubungan dengan yang lain. Aspek perkembangan anak meliputi perkembangan fisik motorik, kognitif, bahasa, dan sosial emosi. Salah satu perkembangan yang penting pada anak usia prasekolah adalah perkembangan social emosi. Anak usia prasekolah merupakan anak usia 3-6 tahun yang mempunyai tanggung jawab besar dalam aktivitas mereka sehari-hari dan menunjukkan tingkat yang lebih matang untuk dapat berinteraksi dengan orang lain.

Sebaliknya, di dalam kebudayaan yang secara hukum menuntut bahwa anak-anak harus mulai mengikuti pendidikan formal pada usia enam tahun, tekanan dan harapan sosial memegang peranan penting dalam menentukan perbedaan anak-anak yang belum dan yang sudah tiba masanya memasuki pendidikan sekolah. Kalau usia formal sekolah 
setahun sebelumnya berarti garis pemisah antara awal dan akhir masa kanak-kanak adalah lima tahun, kalau setahun sesudahnya, berarti garis pemisahnya tujuh tahun. Tekanan dan harapan baru yang mengikuti usia formal sekolah menyebabkan perubahan pola perilaku, minat, dan nilai. Akibatnya, anak-anak menjadi manusia yang "berbeda" dari sebelumnya. Perbedaan ini menyangkut aspek psikologis, bukan pisik, sehingga pemisah dalam rentang usia yang panjang ini menjadi dua bagian, yakni masa awal dan akhir kanakkanak dapat diberikan.

\section{B. Ciri-Ciri Awal Masa Kanak-Kanak}

Perkembangan seorang anak diharapkan dapat berjalan dengan holistik artinya setiap perkembangan yang ada pada dirimanusia berkembang dengan baik. Perkembangan memiliki beberapa bagian setiap bagian perkembangan yang berkembangan dengan baik akan memberikan persiapan pada masa yang akan datang bagi seorang individu. Salah satu jenis perkembangan adalah motorik secara sederhana dapat dilihat pada seorang individu dari sistem koordinasi gerak dan ototnya.

Salah satu ciri tertentu masa bayi merupakan ciri khas yang membedakannya dengan periode-periode lain dalam rentang kehidupan, demikian pula halnya dengan ciri tertentu dari periode awal masa kanak-kanak. Ciri ini tercermin dalam sebutan yang biasanya diberikan oleh para orang tua, pendidik, dan ahli psikologi. Sebagan besar orang tua menganggap awal masa kanak-kanak sebagai usia yang mengundang masalah atau usia sulit. Masa bayi sering membawa masalah bagi orang tua dan umumnya berkisar pada masalah perawatan pisik bayi. Dengan datangnya masa kanak-kanak, sering terjadi masalah perilaku yang menyulitkan daripada masalah perawatan pisik masa bayi. 
Alasan mengapa masalah perilaku lebih sering terjadi diawal masa kanak-kanak ialah karena anak-anak muda sedang dalam proses pengembangan kepribadian yang unik dan menuntut kebebasan yang pada umumnya kurang berhasil. Lagi pula, anak ayng lebih muda seringkali bandel, keras kepala, tidak menurut negativistis, dan melawan. Seringkali marah tanpa alasan. Pada malam hari terganggu oleh mimpi buruk dan pada siang hari ada rasa takut yang tidak rasional, dan merasa cemburu.

Karena perbagai masalah tersebut, maka bagi orang tua pada umumnya masa awal kanak-kanak tampaknya merupakan usia yang kurang menarik dibandingkan masa bayi. Ketergantungan bayi yang sangat mengundang kasih sayang para orang tua dan kakak-kakaknya, sekarang berubah, anak tidak mau ditolong dan cenderung menolak ungkapan kasih sayng mereka. Lagi pula hanya beberapa orang anak yang lebih muda saja yang manis seperti bayi, sehingga membuat anak dalam periode ini kurang menarik.

Seringkali orang tua menganggap masa awal kanak-kanak sebagai usia mainan karena anak muda menghabiskan sebagian besar waktu juga bermain dengan mainannya. Peyelidikan tentang permainan anak menunjukkan bahwa bermain dengan mainan mencapai puncaknya pada tahun-tahun awal masa kanak-kanak, kemudian mulai menurun saat anak mencapai usia sekolah. 

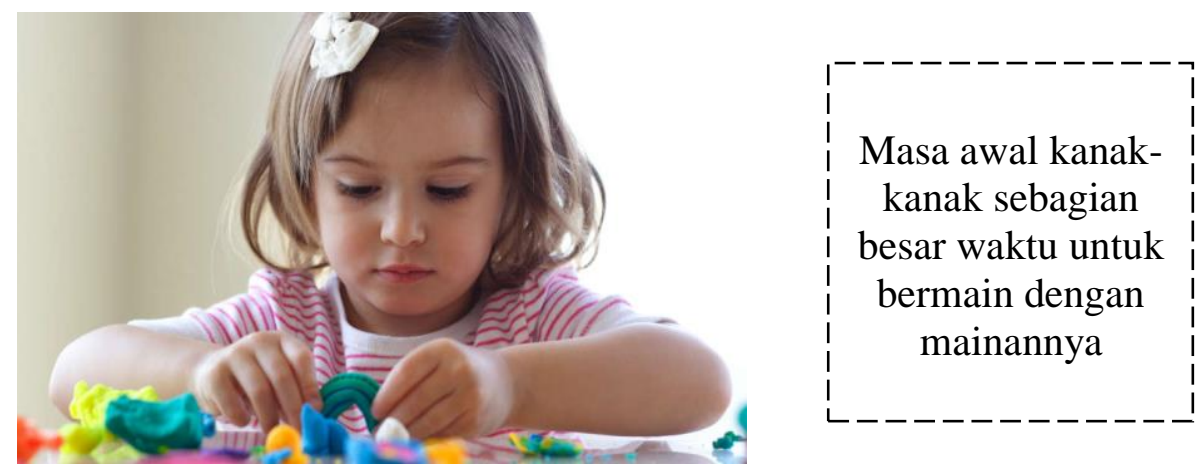

Gambar 6. Masa Awal Kanak-Kanak

Hal ini tentu saja tidak berarti bahwa minat untuk bermain dengan mainan segera berhenti kalau anak masuk sekolah. Dengan masuknya ke kelas satu, anak-anak didorong untuk melakukan berbagai permainan dan berbagai bentuk olah raga yang disesuaikan dan tidak ada satu pun yang menggunakan mainan. Namun kalau sendiri, anak bermain lagi dengan mainannya sampai kelas tiga atau malahan sampai kelas empat. Selama tahun prasekolah, taman kanakkanak, pusat penitipan anak-anak dan kelompok bermain, semuanya menekankan permainan yang memakai mainan. Akibatnya, baik sendiri atau berkelompok, mainan merupakan unsur yang penting dari aktivitas bermain mereka.

Para pendidik menyebut tahun-tahun awal masa kanak-kanak sebagai usia prasekolah untuk membedakannya dari saat di mana anak dianggap cukup tua, baik secara pisik dan mental, untuk menghadapi tugas-tugas pada saat mereka mulai mengikuti pendidikan formal. Anak yang mengikuti taman indria atau taman kanak-kanak juga dinamakan anak-anak prasekolah dan bukan anak-anak sekolah. Di rumah, di pusat-pudat perawatan, taman indria atau taman kanakkanak, tekanan dan harapan yang di kenakan kepada anak-anak sangat berbeda dengan apa yang dialaminya pada saat memulai pendidikan 
formal di kelas satu. Awal masa kanak-kanak, baik di rumah maupun di lingkungan prasekolah, merupakan masa persiapan (Hurlock, 1980).

Para ahli psikologi menggunakan sejumlah sebutan yang berbeda untuk menguraikan cri-ciri yang menonjol dari perkembangan psikologis anak selama tahun-tahun awal masa kanak-kanak. Salah satu sebutan yang banyak digunakan adalah usia kelompok, masa di mana anak-anak mempelajari dasar-dasar perilaku sosial sebagai persiapan bagi kehidupan sosial yang lebih tinggi yang diperlukan untuk penyesuaian diri pada waktu mereka masuk kelas satu.

Rahyubi (2012) menjelaskan perubahan gerak merupakan sebuah perubahan dalam perilaku gerak yang mampu merefleksikan adanya interaksi kematangan seorang dengan lingkungannya. Perkembangan gerak akan mengubah kompetensi gerak manusia yang diawali sejak masa bayi hingga dewasa yang melibatkan berbagai aspek perilaku seseorang karena perkembangan utama yang terjadi selama masa awal masa kanak-kanak berkisar di seputar penguasaan dan pengendalian lingkingan, banyak ahli psikologi melabelkan awal masa kanak-kanak sebagai usia menjelajah, sebagai lebel yang menunjukkan bahwa anak-anak ingin mengetahui keadaan lingkungannya, bagaimana mekanismenya, bagaimana perasaannya dan bagaimana ia dapat menjadi bagian dari lingkungan. Ini termasuk manusia dan juga benda mati. Salah satu cara yang umum dalam menjelajahi lingkungan adalah dengan bertanya; jadi periode ini sering disebut sebagai usia bertanya. 

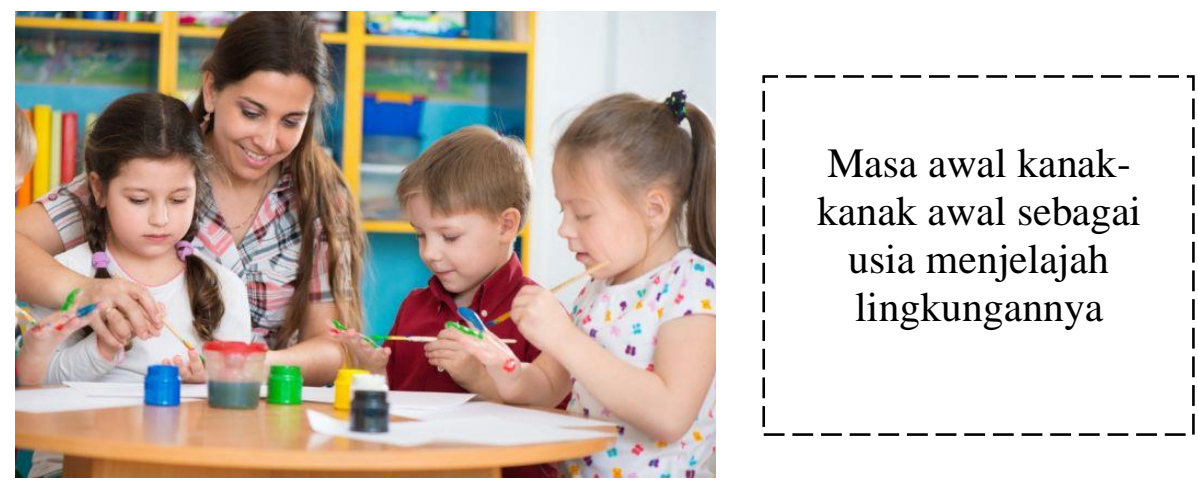

Gambar 7. Masa Menjelajahi Lingkungan

Yang paling menonjol dalam periode ini adalah meniru pembicaraan dan tindakan orang lain. Oleh karena itu, periode ini juga dikenal sebagai usia meniru. Namun meskipun kecenderungan ini tampak kuat tetapi anak lebih menunjukkan kreativitas dalam bermain selama masa kanak-kanak di bandingkan dengan masa-masa lain dalam kehidupannya. Dengan alasan ini, ahli psikologi juga menamakan periode ini sebagai usia kritis dan kreatif (Hamzah, 2006).

\section{Tugas Perkembangan Masa Kanak-Kanak}

Meskipun dasar dari tugas dalam perkembangan yang diharapkan sudah dikuasai anak sebelum mereka masuk sekolah diletakkan selama masa bayi, tetapi masih banyak yang harus dipelajari dalam waktu empat tahun, ayitu dalam priode awal masa kanak-kanak yang relatif singkat. Pada saat masa bayi berakhir, semua bayi normal telah belajar berjalan meskipun dalam tingakat kecakapan yang berbeda-beda; telah belajar makan- makanan keras; dan telah mencapai tingakt stabilitas fisiologis yang cukup baik. Tugas pokok dalam belajar mengendalikan pembuangan kotoran sudah hampir 
sempurna dan akan sepenuhnya dikuasai dalam setahun atau dua tahun lagi.

Meskipun sebagian besar bayi telah menambah kosakata yang berguna, telah dapat dengan tepat mengucapkan kata-kata yang mereka gunakan, dapat mengerti arti dari pernyataan dan perintah yang sederhana, dan dapat menggabungkan beberapa kata menjadi kalimat yang berarti, namun kemampuan mereka untuk berkomunikasi dengan orang lain dan untuk mengerti apa yang dikatakan orang lain masih dalam taraf yang rendah. Masih banyak yang harus dikuasai sebelum mereka masuk sekolah. Mereka juga sudah mempunyai pegertian sederhana mengenai kenyataan sosial dan fisik tetapi masih sangat kurang untuk menghadapi cakrawala sosial serta lingkungan fisik yang semakin meluas. Hanya sedikit bayi yang mengetahui perbedaan seks lebih dari sekedar unsur dasarnya, dan lebih sedikit lagi yang mengetahuitentang aerti sopan-santun seksual. Masih diragukan apakah setiap abyi yang memasuki awal masa kanak-kanak benar-benar mengerti mengenai penampilan seks yang benar, dan mereka hanya sedikit mengerti tentang perilaku seks yang benar.

Pendidikan anak usia dini (PAUD) di Indonesia adalah kebijakan yang masih baru. Pendidikan anak usia dini menjadi booming sejak dipublikasikannya hasil riset mutakhir di bidang neuroscience dan psikologi. Hasil penelitian mengenai perkembangan otak pada usia dini (0-8 tahun, dalam konvensi internasional) mengalami percepatan hingga $80 \%$ dari keseluruhan otak orang dewasa. Hal ini berarti bahwa perkembangan, potensi serta dasar perilaku telah mulai terbentuk pada masa tersebut sehingga disebut sebagai periode "golden age" (periode emas)

Demikian pula hanya dengan pengertian tentang benar dan salah. Pengetahuan tentang benar dan salah msih terbatas pada 
situasi rumah dan harus diperluas dengan pengertian benar dan salah dalam hubungannya dengan orang-orang di luar rumah terutama di lingkungan tetangga, sekolah dan teman bermain.Lebih penting lagi anak-anak harus meletakkan dasar-dasar untuk hati nurani sebagai bimbingan untuk perilaku benar dan salah. Hati nurani berfungsi sebagai sumber motivasi bagi anak-anak untuk melakukan apa yang diketahuinya sebagai hal yang salah bilamana mereka sudah terlalu besar untuk selalu diawasi orang tua atau pengganti orang tua(Fahyuni, 2018).

Salah satu yang terpenting dan yang bagi banyak anak-anak merupakan tugas perkembangan yang paling sulit adalah belajar untuk berhubungan secara emosional dengan orang tua, saudara-saudara kandung, dan orang-orang lain. Hubungan emosional yang terdapat selama masa bayi harus diganti dengan hubungan yang lebih matang. Alasannya adalah karena hubungan dengan orang lain dalam masa bayi berdasarkan pada ketergantungan bayi pada orang lain untuk memenuhi kebutuhan emosionalnya, terutama kebutuhan kasih sayang. Tetapi anak-anak harus belajar memberi dan menerima kasih sayang. Dalam peralihan lingkungan dari TK ke SD, anak akan menemui orang-orang baru dan dalam kegiatannya muncul tuntutan baru, yakni anak dituntut mampu bersosialisasi dalam artian anak mampu bergaul, saling berbagi, mampu mengekspresikan emosi dengan benar dan tidak menyakiti orang lain, percaya diri, mandiri (tidak bergantung lagi pada orang tua) dan lainnya yang berhubungan dengan sosial dan emosi anak.

Umumnya, kesiapan adalah hal krusial yang penting diketahui dan diaplikasikan dalam proses apapun. Teori dan hasil penelitian mengenai mengapa kesiapan perlu menjadi perhatian pemerhati pendidikan banyak ditemukan. Teori Konstruktivis dari Piaget yang disebut juga sebagai teori perkembangan intelektual atau teori 
perkembangan mental memuat teori yang berkenaan dengan kesiapan yang dikemas dalam tahap perkembangan intelektual dari lahir hingga dewasa (sensorimotorik, praoperasional, operasional konkret, operasional formal).

Implikasi dari teori ini dalam pendidikan adalah bahwa kita tidak dapat mengajarkan sesuatu pada seseorang bila belum ada kesiapan (readiness) yang merujuk kepada kematangannya (Suyono, 2011). Intinya bahwa masukan pembelajaran harus match dengan perkembangan skema seseorang. Kesiapan atau readiness itu sendiri diartikan sebagai sebuah kondisi secara keseluruhan dari seseorang yang membuatnya siap untuk memberikan respon atau jawaban di dalam cara tertentu terhadap berbagai situasi. Anak siap atau tidak siap bersekolah dipengaruhi oleh keluarga mereka dan sekolah. Dalam dokumen UNESCO, The Contribution of Early Childhod Education to a Sustainable Society dikatakan bahwa keluarga, sebagai pendidik anakanak yang pertama, memiliki pengaruh yang sangat besar dalam mengarahkan sikap, nilai, perilaku, kebiasaan dan keterampilan anak. Meskipun pendidikan anak usia dini sudah tersedia, tetapi pendidikan orang tua tetap penting dilakukan untuk menjembatani relasi positif antara pendidikan orang tua dalam keluarga dan lembaga pendidikan formal dan non-formal yang menyelenggarakan layanan untuk anak usia dini. Dari berbagai karakteristik keluarga, tingkat pendidikan dan pendapatan merupakan sesuatu yang besar pengaruhnya terhadap perkembangan anak.

Pola pengasuhan anak juga berhubungan langsung dengan perkembangan anak. Diindikasikan bahwa semakin tinggi tingkat pendidikan orang tua akan semakin baik pula cara pengasuhan anak, dan akibatnya perkembangan anak akan berkembang positif. Selain itu lingkungan rumah yang kondusif, fasilitas belajar yang memadai juga 
menjadi penting bagi kesiapan belajar anak. Ditinjau secara parsial, tingkat pendidikan ibu sepertinya mempengaruhi kesiapan bersekolah pada anak daripada tingkat pendidikan ayah. Hal ini berarti bahwa peranan ibu dalam upaya pengembangan kemampuan dasar anak lebih besar daripada ayah mengingat secara kuantitas, ibu memiliki waktu yang lebih banyak bersama anak sehingga mendapatkan kesempatan lebih besar dalam pengaturan atau pengontrolan pertumbuhan dan perkembangan anak (Srihnayani, 2017). 


\section{PERKEMBANGAN MASA KANAK-KANAK}

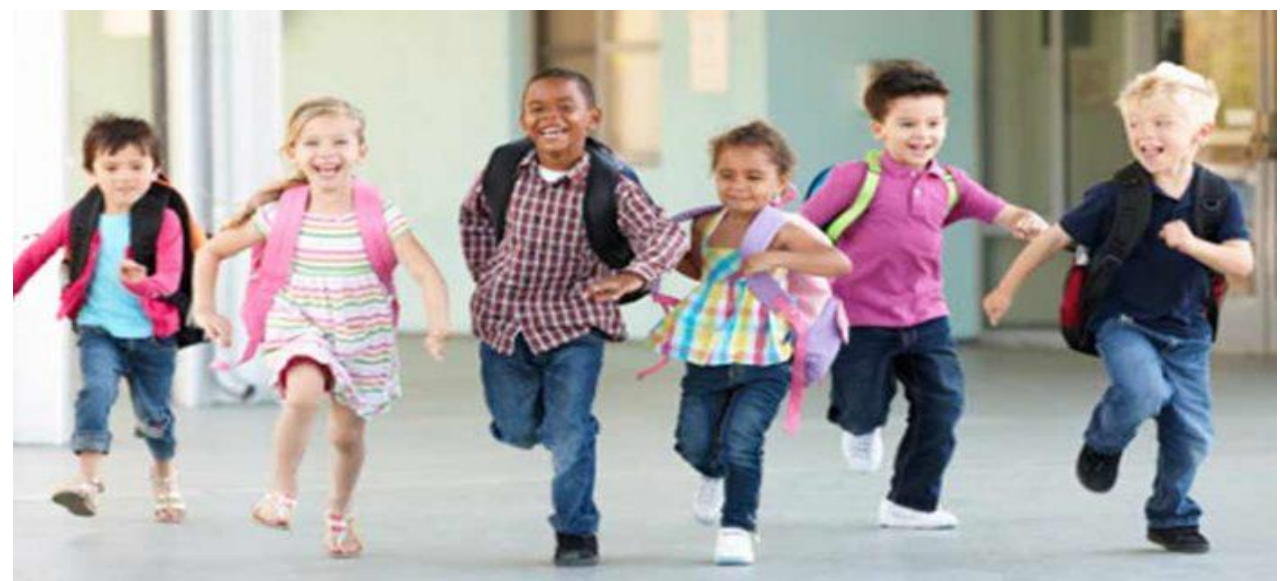

\section{Tinggi}

\section{Tulang dan Otot}

Pertambahan tinggi badan setiap Tingkat pengerasan otot bervariasi tahunnya rata-rata tiga inci. Pada usia pada bagian-bagian tubuh mengikuti enam tahun tinggi anak rata-rata 46,6 hukum perkembangan arah. Otot inci.

\section{Berat}

Pertambahan berat badan setiap tahunnya rata-rata tiga sampai lima pon. Pada usia enam tahun berata anak harus kuarang lebih tujuh kali berat pada waktu lahir. Anak perempuan rata-rata beratnya 48,5 pon dan anak laki-laki 49 pon. menjadi lebih besar, lebih kuat dan lebih berat, sehingga anak tampak lebih kurus meskipun beratnya bertambah.

\section{Lemak}

Anak-anak yang cenderung bertubuh endomorfik lebih banyak jaringan lemaknya daripada jaringan otot; yang cenderung mesomorfik mempunyai jaringan otot lebih banyak daripada jaringan lemak; dan yang bertubuh ektomorfik mempunyai otot-otot yang kecil dan sedikit jaringan lemak. 


\section{Perbandingan Tubuh}

Perbandingan tubuh sangat berubah dan "penampilan bayi" tidak tampak lagi. Wajah tetap kecil tetapi dagu tampak lebih jelas dan leher lebih memanjang. Gumpalan pada bagianbagian tubuh berangsur-angsur berkurang dan tubuh cenderung berbentuk kerucut, dengan perut yang rata (tidak buncit), dada yang lebih bidang dan rata, dan bahu lebih luas dan lebih persegi. Lengan dan kaki lebih panjang dan lebih lurus, tangan dan kaki tumbuh lebih besar.

\section{Postur Tubuh}

Perbedaan dalam postur tubuh untuk pertama kali tampak jelas dalam awal kanak-kanak. Ada yang posturnya gemuk atau endomorfik, ada yang kuat berotot atau mesomorfik dan ada lagi yang relatif kurus atau ektomorfik.

\section{Gigi}

Selama empat sampai enam bulan pertama dari awal masa kanak-kanak, empat gigi bayi yang terakhir-geraham belakang-muncul. Selama setengah tahun terakhir gigi bayi mulai tanggal digantikan oleh gigi tetap. Yang mulamula lepas adalah gigi bayi yang pertama kali tumbuh yaitu gigi seri tengah. Bila masa awal kanak-kanak berakhir, pada umumnya bayi memiliki satu atau dua gigi tetap di depan dan beberapa celah di mana gigi tetap akan muncul.

Sekalipun pola perkembangan yang diuraikan di atas dapat diramalkan tetapi terdapat beberapa perbedaan individual dalam semua aspek perkembangan fisik. Anak dengan tingkat kecerdasan yang tinggi, misalnya, tubuhnya cenderung lebih tinggi pada awal masa kanak-kanak daripada mereka yang kecerdasannya rata-rataatau di bawah rata-rata dan gigi sementaranya lebih cepat tanggal. Meskipun perbedaan seks tidak menonjol dalam peningkatan tinggi dan berat tubuh, tetapi pengerasan tulang dan lepasnya gigi sementara lebih cepat pada anak perempuan, dari usia ke usia. Anak 
dari kelompok sosial ekonomi yang lebih tinggi cenderung memperoleh gizi dan perawatan yang lebih baik sebelum dan sesudah kelahiran. Oleh karena itu, perkembangan tinggi, berat dan otot-otot badan cenderung lebih baik.

\section{Kebiasaan Fisiologis}

Pada awal masa kanak-kanak, kebiasaan fisiologis yang dasarnya sudah diletakkan pada masa bayi menjadi semakin baik. Tidak perlu lagi disediakan makanan khusus dan anak belajar makan pada waktuwaktu tertentu. Namun nafsu makan anak-anak tidak sebesar seperti pada masa bayi. Hal ini sebagian disebabkan karena tingkat pertumbuhan telah menurun dan sebagian karena sekarang ia telah mengembangkan jenis makanan yang disukai dan yang tidak disukai. Jumlah tidur yang dibutuhkan sehari-hari juga berbeda, bergantung pada perbagai faktor tertentu seperti banyaknya latihan di siang hari dan macam kegiatan yang dilakukan. Anak-anak usia tiga tahun tidur sekitar dua belas jam sehari. Tahun-tahun berikutnya jumlah tidur sehari-hari rata-rata berkurang sekitar setengah jam dari tahun sebelumnya. Seperti telah ditunjukkan dalam bab sebelumnya, pengendalian pembuangan kotoran telah dikuasai pada masa akhir bayi. Pada usia tiga tahun atau empat tahun anak sudah harus dapat mengendalikan kantung kemih pada malam hari. Pada saat anak-anak siap masuk sekolah pengendalian kantung kemih sudah harus sempurna, sehingga sekalipun merasa lelah dan mengalami ketegangan emosi, anak-anak akan tetap tidak mengompol.

\section{E. Ketrampilan Pada Awal Masa Kanak-Kanak}

Awal masa kanak-kanak merupakan masa yang ideal untuk mempelajari keterampilan tertentu. Terdapat tiga alasan. Pertama, anak sedang mengulang-ulang dan karenanya dengan senang hati mau 
mengulang suatu aktivitas sampai mereka terampil melakukannya. Kedua, anak-anak bersifat pemberani sehingga tidak terhambat oleh rasa takut kalau dirinya mengalami sakit atau diejek teman-temannya sebgaimana ditakuti anak yang lebih besar. Ketiga, anak mudah dan cepat belajar karena tubuh mereka masih sangat lentur dan keterampilan yang dimiliki baru sedikit sehingga keterampilan yang baru dikuasai tidak mengganggu keterampilan yang sudah ada.

Awal masa kanak-kanak dapat diaggap sebagai "saat belajar" untuk belajar keterampilan. Apabila anak-anak tidak diberi kesempatan mempelajari keterampilan tertentu, perkembangannya sudah memungkinkan dan ingin melakukannya karena berkembangnya keinginan untuk mandiri, maka mereka tidak saja akan kurang memiliki dasar keterampilan yang telah dipelajari oleh teman-teman sebayanya tetapi juga akan kurang memiliki motivasi untuk mempelajari pelbagai keterampilan pada saat diberi kesempatan. Keterampilan yang dipelajari bergantung sebagian pada kesiapan kematangan terutama kesempatan yang diberikan untuk mempelajari dan bimbingan yang diperoleh dalam menguasai keterampilan ini secara cepat dan efisien. Telah dilaporkan bahwa anak dari lingkungan yang buruk umumnya lebih cepat dan lebih banyak meguasai keterampilan dibandingkan dengan anak-anak yang berasal dari lingkungan yang lebih baik. Hal ini tidak disebabkan karena ia lebih cepat matang melainkan karena orang tuanya terlampau sibuk sehingga tidak sempat menjaganya terus-menerus bilamana tidak diperlukan lagi

Meskipun terdapat sejumlah perbedaan, setiap anak-anak umumnya belajar keterampilan umum tertentu, meskipun saat mempelajarinya agak berbeda dan kecakapan dalam mempelajarinya juga berbeda. Ketrampilan umum ini dapat dibagi kedalam dua kelompok besar yaitu keterampilan tangan dan keterampilan kaki. 
Keterampilan Tangan Keterampilan dalam makan dan berpakaian sendiri yang mulai pada masa bayi disempurnakan dalam awal masa kanak-kanak. Kemajuan terbesar dalam awal keteranpilan berpakaian umumnya antara usia 1,5 dan 3,5 tahun. Menyisir rambut dan mandi merupakan keterampilan yang mudah dilakukan dalam periode ini. Pada saat anak-anak mencapai usia taman kana-kanak, mereka sudah harus dapat mandi dan berpakaian sendiri, mengikat tali sepatu dan menyisir rambut dengan sedikit bantuan atau tanpa bantuan sama sekali (Hamzah, 2006).

Antara usia lima dan enam tahun sebagian besar anak-anak sudah pandai melempar dan menangkap bola. Mereka dapat menggunakan gunting, dapat membentuk tanah liat, membuat kuekue dan menjahit. Dengan krayon, pensil, dan cat anak-anak dapat mewarnai gambar, menggambar atau mencat gambarnya sendiri dan dapat menggambar orang.

Awal masa kanak-kanak dapat dianggap sebagai periode kritis dalam menentukan pilihan penggunaan tangan. Hal ini disebabkan karena selama periode ini, anak-anak sampai tingkat tertentu meninggalkan kecenderungan untuk menggantikan penggunaan tangan yang satu dengan mneggunakan tangan yang lain dan mulai memusatkan pada keterampilan satu tangan tertentu dan tangan yang lain sebagai tangan pembantu. Ada bukti bahwa kecenderungan lebih disukainya penggunaan tangan yang satu daripada yang lainnya belum sepenuhnya terbentuk sampai antara usia tiga dan enam tahun. Tentu saja ini tidak berarti bahwa anak-anak tidak dapat mengubah dominasi tangan kalau dikehendaki. Misalnya, kalau anak kelas satu ternyata mengalami kesulitan dalam menggunakantangan kirinya ketika ia berusaha meniru guru yang menulis dengan tangan kanan di papan tulis, maka ia dapat berganti dengan menggunakan tangan kanan sebagai tangan yang dominan kalau motivasinya cukup kuat, sehingga 
mengubah kebiasaan penggunaan tangan semakin sulit (Desmita,2009)..

Tidak semua lembaga prasekolah dan pusat perawatan anak menekankan penggunaan tangan kanan tetapi sebagian besar melakukannya. Sebaliknya, banyak orang tua yakin bahwa masalah ini merupakan masalah keturunan, sehingga kalau mereka melihat anaknya cenderung menggunakan tangan kiri maka dianggap bahwa memang kidal. Dengan demikian orang tua tidak berusaha mendorong anak belajar keterampilan baru dengan tangan kanan.

Karena banyak keteranpilan tangan yang dipelajari anak-anak tidak dapat dilakukan dengan satu tangan, maka kedua tangan harus dilatih untuk melaksanakan keterampilan itu. Tetapi hanya sedikit keterampilan yang menuntut peranan kedua belah tangan, sehingga dalam mengajar anak-anak harus ditekankan pada gerakan tangan yang dominan dan tangan yang lain berfungsi sebagai pembantu. Gerakan-gerakan ini seringkali sangat berbeda. Misalnya, dalam hal menggambar dengan krayon, tangan yang dominan memegang krayon dan tangan pembantumemegangn kertas sehingga dapat digambari. Dalam mengancingkan baju, gerakan-gerakan memasukkan anak kancing ke dalam lubangnya dilakukan oleh tangan yang dominan sedangkan tangan pembantu memegang baju sedemikian rupa sehingga kancing dapat dimasukkan ke dalam lubangnya.

\section{F. Kemajuan Berbicara Awal Masa Kanak-Kanak}

Pada saat anak-anak berusia dua tahun, kebanyakan bentukbentuk kominikasi prabicara yang tadinya sangat bermanfaat dalam masa bayi telah ditinggalkan. Anak-anak tidak lagi mengoceh dan tangis mereka sudah sangat berkurang. la mungkin menggunakan isyarat, terutama sebagai pelengkap bagi pembicaraan -untuk menekankan arti kata-kata yang diucapkan -dan bukan sebagai 
pengganti bicara. Tetapi anak-anak terus berkomunikasi dengan orang-orang lain dengan ungkapan-ungkapan emosi yang secara keseluruhan lebih diterima secara sosial dan tidak terlalu dianggap "seperti bayi" daripada bentuk-bentuk prabicara lainnya.

Selama masa awal kanak-kanak anak-anak memiliki keinginan yang kuat untuk belajar berbicara. Hal ini disebabkan karena dua hal. Pertama, belajar berbicara merupakan sarana pokok dalam sosialisasi. Anak-anak yang lebih mudah berkomunikasi dengan teman sebaya akan lebih mudah mengadakan kontak sosial dan lebih mudah diterima sebagai anggota kelompok daripada anak yang kemampuan berkomunikasinya terbatas. Anak-anak yang mengikuti kegiatan prasekolah akan mengalami rintangan baik dalam hal sosial maupun pendidikan kecuali bila ia pandai bicara seperti teman-teman sekelasnya.

Belajar berbicara merupakan sarana untuk memperoleh kemandirian. Anak-anak yang tidak dapat mengemukakan keinginan dan kebutuhannya cenderung tidak berhasil memperoleh kemandirian yang diinginkan. Kalau anak-anak tidak dapat mengatakan kepada orang tua atau pengasuh bahwa mereka ingin mencoba memotong daging atau menyisir rambut sendiri, orang-orang dewasa akan terus membantu karena ia dianggap masih terlalu kecil untuk dapat melakukannya sendiri. Ini menghambat anak untuk menjadi percaya diri dan mandiri.

Untuk meningkatkan komunikasi, anak-anak harus menguasai dua tugas pokok yang merupakan unsur penting dalam belajar. Pertama, mereka harus meningkatkan kemampuan untuk mengerti apa yang dikatakan orang lain dan kedua, mereka harus meningkatkan kemampuan bicaranya sehingga dapat dimengerti orang lain. Para orang tua dan pengasuh biasanya lebih menekankan pada belajar berbicara sehingga tugas meningkatkan pengertian secara tidak 
langsung dilakukan anak sendiri karena adanya keinginan yang kuat untuk berkomunikasi sebagai sarana untuk kegiatan sosial. Untuk dapat berkomunikasi dengan orang-orang lain, anak harus mengerti apa yang dikatakan orang lain. Kalau tidak dapat dimengerti orang lain pembicaraan tidak berhubungan dengan apa yang dikatakan orang lain dan ini akan merusak kontak sosialnya.

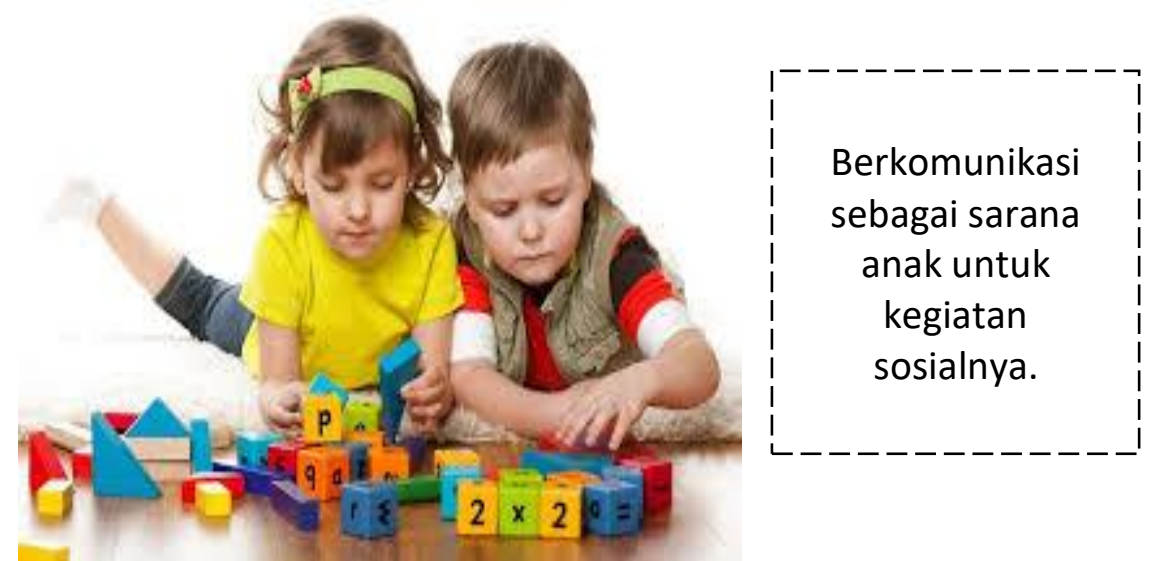

Gambar 8. Berkomunikasi Sebagai Sarana Sosial Anak

Kemampuan mengerti sangat dipengaruhi cara anak mendengarkan apa yang dikatakan kepadanya. Mendengarkan radio dan televisi ternyata sangat membantu karena mendorong anak untuk mendengarkan dengan penuh perhatian. Di samping itu, kalau orang berbicara dengan lambat dan jelas kepada anak, dengan menggunakan kata-kata yang sekiranya dapat dimengerti, hal ini juga dapat mendorong anak untuk mendengarkan dengan baik. Sebaliknya, kalau orang berbicara terlampau cepat dengan menggunakan kata-kata yang sulit, asing dan kalimat majemuk, anak-anak menjadi bingung dan tidak bersemangat karena tidak dapat mengerti apa yag dibicarakan. 
Ini menghambat mereka untuk mencoba menjadi pendengar yang baik. 


\section{BAB IV \\ MASA REMAJA}

\section{A. Karakteristik Masa Remaja}

Masa remaja merupakan masa transisi atau peralihan dari masa anak menuju masa dewasa. Pada masa ini individu mengalami berbagai perubahan, baik fisik maupun psikis. Perubahan yang tampak jelas adalah perubahan fisik, di mana tubuh berkembang pesat sehingga mencapai bentuk tubuh orang dewasa yang disertai pula dengan berkembangnya kapasitas reproduktif. Selain itu remaja juga berubah secara kognitif dan mulai mampu berpikir abstrak seperti orang dewasa. Pada periode ini pula remaja mulai melepaskan diri secara emosional dari orang tua dalam rangka menjalankan peran sosialnya yang baru sebagai orang dewasa (Hurlock, 1980).

Badan Kesehatan Dunia (WHO) memberikan batasan mengenai siapa remaja secara konseptual. Dikemukakannya oleh WHO ada tiga kriteria yang digunakan; biologis, psikologis, dan sosial ekonomi, yakni: (1) individu yang berkembang saat pertama kali ia menunjukkan tanda-tanda seksual sekundernya sampai saat ia mencapai kematangan seksual, (2) individu yang mengalami perkembangan psikologis dan pola identifikasi dari anak-anak menjadi dewasa, dan (3) terjadi peralihan dari ketergantungan sosial ekonomi yang penuh kepada keadaan yang lebih mandiri.

Selain perubahan yang terjadi dalam diri remaja, terdapat pula perubahan dalam lingkungan seperti sikap orang tua atau anggota keluarga lain, guru, teman sebaya, maupun masyarakat pada umumnya. Kondisi ini merupakan reaksi terhadap pertumbuhan remaja. Remaja dituntut untuk mampu menampilkan tingkah laku yang dianggap pantas atau sesuai bagi orang-orang seusianya. Adanya perubahan baik di dalam maupun di luar dirinya itu membuat 
kebutuhan remaja semakin meningkat terutama kebutuhan sosial dan kebutuhan psikologisnya. Untuk memenuhi kebutuhan tersebut remaja memperluas lingkungan sosialnya di luar lingkungan keluarga, seperti lingkungan teman sebaya dan lingkungan masyarakat lain.

Secara umum masa remaja dibagi menjadi tiga bagian, yaitu sebagai berikut:

1. Masa remaja awal (12-15 tahun)

Pada masa ini individu mulai meinggalkan peran sebagai anakanak dan berusaha mengembangkan diri sebagai individu yang unik dan tidak tergantung pada orang tua. Fokus dari tahap ini adalah penerimaan terhadap bentuk dan kondisi fisik serta adanya konformitas yang kuat dengan teman sebaya.

2. Masa remaja pertengahan (15- 18 tahun)

Masa ini ditandai dengan berkembangnya kemampuan berpikir yang baru. Teman sebaya masih memiliki peran yang penting, namun individu sudah lebih mampu mengarahkan diri sendiri (self-directed). Pada masa ini remaja mulai mengembangkan kematangan tingakah laku, belajar mengendalikan impulsivitas, dan membuat keputusan-keputusan awal yang berkaitan dengan tujuan vokasional yang ingin dicapai. Selain itu penerimaan dari lawan jenis menjadi penting bagi individu.

3. Masa remaja akhir (19-22 tahun)

Masa ini ditandai oleh persiapan akhir untuk memasuki peranperan orang dewasa. Selama periode ini remaja berusaha memantapkan tujuan vokasional dan mengembangkan sence of personal identity. Keinginan yang kuat untuk menjadi matang dan diterima dalam kelompok teman sebaya dan orang dewasa, juga menjadi ciri dari tahap ini. 


\section{B. Perubahan pada Masa Remaja}

Masa remaja dikenal sebagai salah satu periode dalam renang kehidupan manusia yang memilik beberapa keunikan tersendiri. Keunikan tersebut bersumber dari kedudukan masa remaja sebagai periode transisional antara masa kanak-kanak dan masa dewasa. Kita semua megetahui bahwa antara anak-anak dan orang dewasa ada beberapa perbedaan yang selain bersifat biologis atau fisiologis juga bersifat psikologis(Fahyuni, 2016). Pada masa remaja perubahanperubahan besar terjadi dalam kedua aspek tersebut, sehingga dapat dikatakan bahwa ciri umum yang menonjol pada masa remaja adalah berlangsungnya perubahan itu sendiri, yang dalam interaksinya dengan lingkungan sosial membawa berbagai dampak pada perilaku remaja. Secara ringkas, proses perubahan tersebut dan interaksi antara beberapa aspek yang berubah selama masa remaja bisa diuraikan seperti berikut ini.

\section{Perubahan Fisik}

Rangkaian perubaha yang paling jelas yang mnampak dialami oleh remaja adalah perubahan biologis dan fisiologis yang berlangsung pada masa pubertas atau pada awal masa remaja, yaitu sekitar umur 11-15 tahun pada wanita dan 12-16 tahun pada pria (Hurlock, 1980). Hormon-hormon baru diproduksi oleh kelenjar endokrin, dan ini membawa perubahan dalam ciri-ciri seks primer dam memunculkan ciri-ciri seks sekunder. Gejala ini memberi isyarat bahwa fungsi reproduksi atau kemampuan untuk menghasilkan keturunan sudah mulai bekerja. Seiring dengan itu, berlangsung pula pertumbuhan yang pesat pada tubuh dan anggota-anggota tubuh untuk mencapai proporsi seperti orang dewasa. Seorang individu lalu mulai terlihat berbeda, dan sebagai konsekuensi dari hormon yang baru, dia sendiri mulai merasa adanya perbedaan. 
2. Perubahan Emosionalitas

Akibat langsung dari perubahan fisik dan hormonal tadi adalah perubahan dalam aspek emosionalitas pada remaja sebagai akibat dari perubahan fisik dan hormon tadi, dan juga pengaruh lingkungan yang terkait dengan perubahan badaniah tersebut. Hormonal menyebabkan perubahan seksual dan menimbulkan dorongan-dorongan dan perasaan-perasaan baru. Keseimbangan hormonnal yang baru menyebabkan inidividu merasakan hal-hal yang belum pernah dirasakan sebelumnya. Keterbatasannya untuk secara kognitif mengolah perubahan-perubahan baru tersebut bisa membawa perubahan besar dalam fluktiasi emosinya. Dikombinasikan dengan pengaruh-pengaruh sosial yang juga senantiasa berubah, seperti tekanan dari teman sebaya, media masa, dan minat pada jenis seks lain, renaja menjadu lebih terorientasi secara seksual. Ini semua menuntut kemampuan pengendalian dan pengaturan baru atas perilakunya.

3. Perubahan Kognitif

Semua perubahan fisik yang membawa implikasi perubahan emosional tersebut makin dirumitkan oleh fakta bahwa individu juga sedang mengalami perubahan kognitif. Perubahan dalam kemampuan berpikir ini diungkapkan oleh Piaget (1972) sebagai tahap terakhir yang disebut sebagai tahap formal operation dalam perkembangan kognitifnya. Dalam tahap yang bermula pada umur 11 atau 12 tahun ini, remaja tidak lagi terikat pada realitas fisik yang konkrit dari apa yang ada, remaja mulai mampu berhadapan dengan aspek-aspek yang hipotetis dan abstrak dari realitas. Bagaimana dunia ini tersusun tidak lagi dilihat sebagai satu-satunya alternatif yang mungkin terjadi, misalnya, aturanaturan dari orang tua, status remaja dalam kelompok sebayanya, dan aturan-aturan yang diberlakukan padanya tidak lagi 
dipandang sebagai hal-hal yang tak mungkin berubah. Kemampuan-kemampuan berpikir yang baru ini memungkinkan inidividu untuk berpikir secara abstrak, hipotetis dan kontrafaktual, yang pada gilirannya kemudian memberikan peluang bagi individu untuk mengimajinasikan kemungkinan lain untuk segala hal. Imajinasi ini bisa terkait pada kondisi masyarakat, diri sendiri, aturan-aturan orang tua, atau apa yang akan dia lakukan dalam hidupnya. Singkatnya, segala sesuatu menjadi fokus dari kemampuan berpikir hipotetis, kontrafaktual, dan imajinatif dari remaja.

4. Implikasi Psikososial

Semua perubahan yang terjadi dalam waktu yang singkat itu membawa akibat bahwa fokus utama dari perhatian remaja adalah dirinya sendiri. Secara psikologis proses-proses dalam diri remaja semuanya tengah mengalami perubahan, dan komponenkomponen fisik, fisiologis, emosional, dan kognitif sedang mengalami perubahan besar. Sekarang dengan terbukanya kemungkinan bagi semua objek untuk dipikirkan dengan cara yang hipotetis, berbeda dan baru, dan dengan perubahan dirinya yang radikal, sepantasnyalah bagi individu untuk memfokuskan pada dirinya sendiri dan mencoba mengerti apa yang sedang terjadi.Individu akan bertanya: "Apa dasar dari perubahan ini?", Apa akibatnya pada saya? Saya akan menjadi apa? Adakah saya sama seperti orang yang saya pikirkan? Ketidakpastianketidakpastian seperti ini, membawa seperangkat persoalan yang baru, persoalan ini ada kaitannya dengan peran remaja secara sosial.

Pada saat remaja menghadapi semua keprihatinan tersebut, yaitu pada saat di mana remaja sangat tidak siap untuk berkutat dengan kerumitan dan ketidakpastian, berikutnya muncul faktor- 
faktor lain yang enimpa dirinya. Remaja dalam masyarakat kita secara tipikal dituntut untuk membuat satu pilihan, suatu keputusan tentang apa yang akan dia lakukan bila dewasa. Masyarakat, melalui orang tua atau guru, bertnya kepada remaja untuk memilih satu peran.

Dalam masyarakat kita ketika anak memasuki SMA, anak harus sudah memilih jurusan pendidikan yang akan ditempuh yang akhirnya akan menentukan perannya nanti. Jadi ketika berumur sekitar 15 atau 16 tahun seseorang sudah mulai menempatkan dirinya pada satu jalur yang akan membawa akibat pada apa yang akan dilakukannya pada tahun-tahun selanjutnya. Masalahnya terjadi tepat pada saat ketika remaja berada dalam posisi yang sangat tidak siap untuk mengambil keputusan yang berakibat jangka panjang, mereka malah diminta untuk melakukannya. Karenanya banyak renaja berada dalam dilema. Mereka tidak bisa menjawab pertanyaan tentang peran sosial yang akan mereka jalankan tanpa menyelesaikan beberpa pertanyaan lain tentang dirinya sendiri. Jawaban terhadap perangkat pertanyaan yang satu saling tergantung dengan jawaban terhadap rangkaian pertanyaan yang lain. Perasaan tertentu yang berada dalam situasi krisis bisa muncul, krisis yang membutuhkan jawaban yang tepat tentang siapa sebenarnya dirinya. Ini adalah pertanyaan tentang definisi diri, tentang identifikasi diri. Erikson menamai dilema ini sebagai krisis identitas.

Menurut Erikson (1968), seorang remaja bukan sekedar mempertanyakan siapa dirinya, tapi bagaimana dan dalam konteks apa atau dalam kelompok apa dia bisa menjadi bermakna dan dimaknakan. Dengan kata lain, identitas seseorang tergantung pula pada bagaimana orang lain mempertimbangkan kehadirannya. Karenanya bisa lebih dipahami mengapa keinginan untuk diakui, keinginan untuk memperkuat kepercayaan diri, dan keinginan untuk 
menegaskan kemandirian menjadi hal yang sangat penting bagi remaja, terutama mereka yang akan mengakhiri masa itu.
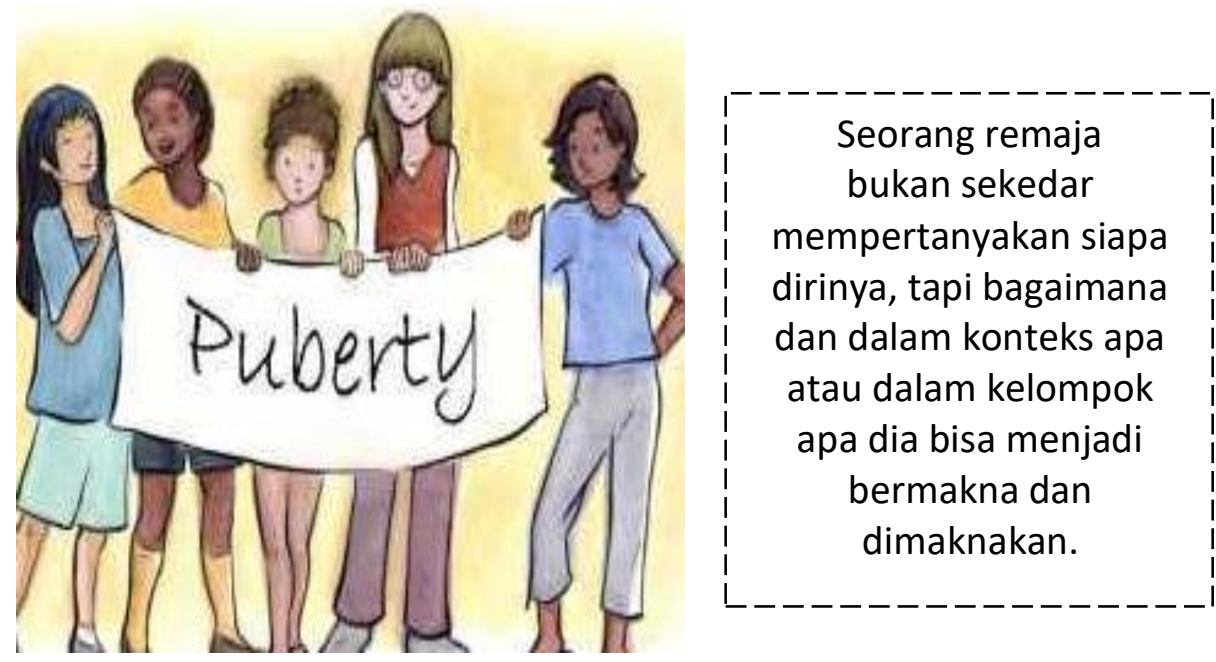

Gambar 9. Dilema Seorang Remaja

Hurlock (1980) mengungkapkan bahwa penyesuaian diri merupakan salah satu faktor penyebab munculnya kecemasan. Penyesuaian diri merupakan salah satu hal penting yang harus dimiliki pada individu yang akan menghadapi peristiwa dimana anak-anaknya akan pergi meninggalkan rumah untuk kehidupan yang lebih mandiri. Duberman (Feldman, 1989) menyatakan bahwa ada kemungkinan terjadi perubahan yang besar dalam kualitas pernikahan hanya karena anak-anak telah dewasa. Hal tersebut juga dipertegas oleh Bassoff (dalam Santrock, 2002), bahwa sebuah peristiwa penting dalam keluarga adalah beranjaknya seorang anak ke dalam kehidupan 
dewasa, karir atau keluarga yang terlepas dari keluarga tempat anak berasal.

Faktor lain yang membantu proses penyesuaian diri adalah hubungan yang baik dengan teman sebaya. Responden dalam penelitian ini melakukan aktivitas bersama teman-temannya untuk mengisi waktu luang yang dimiliki dan juga untuk mengurangi kesepian yang dirasakan, berpartisipasi dalam organisasi sosial dan organisasi kemasyarakatan perlu dilakukan oleh individu, upaya ini dilakukan untuk memperpanjang usia harapan hidup dan masa produktif, serta mewujudkan kemandirian dan kesejahteraan dalam memelihara sistem nilai budaya dan kekerabatan (Makkar, 2015).

Menurut Jhon Hill (1983), terdapat tiga komponen dasar dalam membahas periode remaja, yaitu:

1) Perubahan fundamental remaja meliputi perubahan biologis, kognitif, dan sosial. Ketiga perubahan ini bersifat universal.

a. Perubahan biologis (ciri-ciri secara primer dan sekunder).

Perubahan ini mengakbatkan remaja harus menyesuaikan diri terhadap lingkungan di sekitarnya. Perubahan fisik ini juga berpengaruh terhadap self image remaja dan juga menyebabkan perasaan tentang diri pun berubah. Hubungan dengan keluarga ditampilkan remaja dengan menunjukkan kebutuhan akan privacy yang cukup tinggi.

b. Transisi kognitif

Perubahan dalam kemampuan berpikir, remaja telah memiliki kemampuan yang lebih baik dari anak dalam berpikir mengenai situasi secara hipotetis, memikirkan sesuatu yang belum terjadi tetapi akan terjadi. la pun telah mampu berpikr tentang konsep-konsep yang abstark seperti pertemanan, demokrasi, moral. Remaja pun telah mampu berpikir secara 
logis tentang kehidupannya seperti : kehidupan apa yang akan ia tempuh dikemudian hari, tentang hubungannya dengan teman dan keluarga, tentang politik, kepercayaan dan filsafat.

c. Transisi sosial

Perubahan dalam status sosial membuat remaja mendapatkan peran-peran baru dan terikat pada kegiatan-kegiatan baru. Semua masyarakat membedakan antara individu sebagai anak dan individu yang siap memasuki masa dewasa. 


\section{Konsep Tugas Perkembangan}

Perkembangan diawali dengan memahami konsep tugas perkembangan dari oerter sebagai berikut :

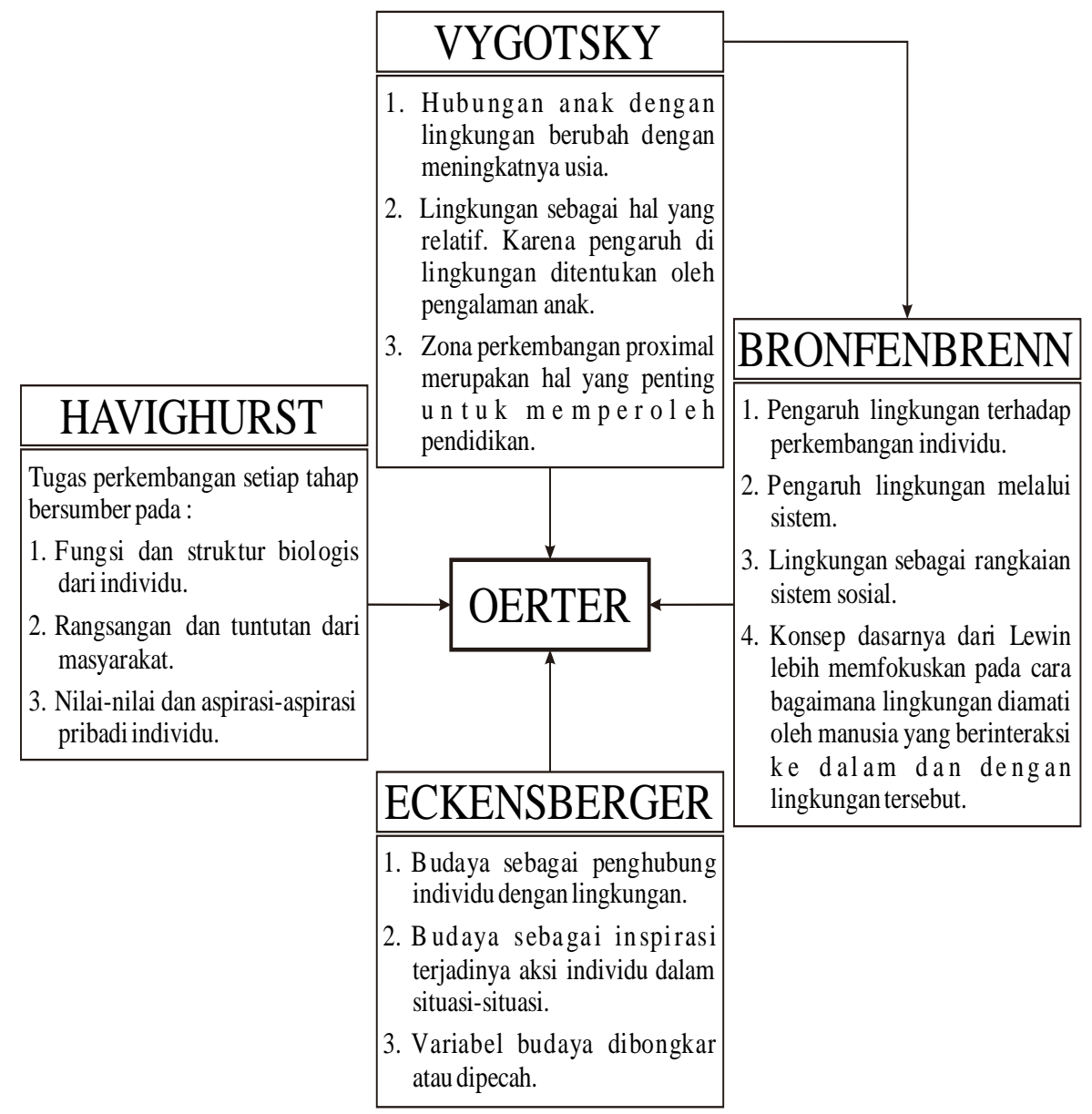

Gambar 10. Konsep Tugas Perkembangan (Oerter, 1983) 
Konsep tugas perkembangan remaja mengacu pada konsep tugas perkembangan Havighurst membuat penjelasan secara dinamik dengan menggunakan pendekatan action theory dari Eckenberger dan pendekatan Ekologi dari Bronfenbrenner. Pada mulanya Pendekatan Ekologi digunakan untuk membahas konsep tugas perkembangan ditawarkan oleh Vygotsky. Vygotsky mengungkapkan bahwa hubungan anak dengan lingkungan berubah dengan meningkatnya usia oleh karena itu peran dari lingkungan dalam perkembangan seorang remaja pun mengalami perubahan. Dengan demikian lingkungan harus dianggap sebagai hal yang relatif, karena pengaruh dari lingkungan ditentukan oleh pengalaman anak. Untuk menyoroti interaksi yang berubah ini Vygotsky (1968) mengajukan gagasan mengenai pengalaman anak. Konsep pengalaman dari Vygotsky merupakan realita psikologis yang penting, analisis pengalaman dimulai dari penelitian tentang peranan lingkungan dalam perkembangan anak. Pengalaman merupakan inti dari semua pengaruh yang berbeda-beda dari keadaan-keadaan internal dan eksternal.

Seperti halnya pada semua periode yang penting, rentang kehidupan masa remaja mempunyai ciri-ciri tertentu yang membedakannya dengan periode sebelumnya dan sesudahnya. Masa remaja ini, selalu merupakan masa-masa sulit bagi remaja maupun orangtuanya. Menurut Sidik Jatmika, (2010) kesulitan remaja itu berangkat dari fenomena remaja sendiri dengan beberapa perilaku khusus; yakni:

1. Remaja mulai menyampaikan kebebasannya untuk mengemukakan pendapatnya sendiri. Tidak terhindarkan, ini dapat menciptakan ketegangan dan perselisihan, dan bias menjauhkan remaja dari keluarganya.

2. Remaja lebih mudah dipengaruhi oleh teman-temannya daripada ketika mereka masih kanak-kanak. Ini berarti bahwa pengaruh 
orangtua semakin lemah. Anak remaja berperilaku dan mempunyai kesenangan yangberbeda bahkan bertentangan dengan perilaku dan kesenangan keluarga. Contoh-contoh yang umum adalah dalam hal mode pakaian, potongan rambut, kesenangan musik yang kesemuanya harus mutakhir.

3. Remaja mengalami perubahan fisik yang luar biasa, baik pertumbuhannya maupun seksualitasnya. Perasaan seksual yang mulai muncul bisa menakutkan, membingungkan dan menjadi sumber perasaan salah dan frustrasi.

4. Remaja sering menjadi terlalu percaya diri (over confidence) dan ini bersama-sama dengan emosinya yang biasanyameningkat, mengakibatkan sulit menerima nasihat dan pengarahan oangtuaPendidikan tidak boleh berorientasi pada fungsi-fungsi perkembangan yang telah terbentuk dan siklus perkembangan yang sudah berlaku, tapi harus berorientasi pada jenis-jenis pematangan. Kemungkinan memperoleh pendidikan terutama ditentukan oleh zona perkembangan proximal.

Action theory dari Eckensberger (1979) keterkaitannya dengan konsep tugas perkembangan remaja adalah dalam penjelasan mengenai :

1) Budaya sebagai penghubungan antara individu dengan lingkungan.

2) Budaya sebagai inspirasi terjadinya aksi individu dalam suatu situasi.

3) Budaya sebagai kumpulan dari kondisi: kultur merupakan faktor tingkat tinggi yang tidak memiliki status independent variabel, maka sangat tidak mungkin untuk diukur. Maka dilakukan "Ecological Analysis", budaya dipecah-pecah kedalam faktorfaktor kontekstual, ide dasarnya adalah pembongkaran variabelvariabel budaya. 
Bronfenbrenner, menjelaskan mengenai pengaruh lingkungan terhadap perkembangan seseorang inidividu. Lingkungan dibuat sistem-sistem yang diharapkan akan lebih memudahkan untuk menjelaskan pengaruh dari lingkungan terhadap perkembangan individu. Dalam konteks Pendekatan Ekologi yang mempunyai unsur masa lalu (kemampuan individu yang telah ada), masa kini (tujuan perkembangan saat ini) dan masa datang (harapan dari lingkungan). Proses dari unsur-unsur Pendekatan Ekologi ini akan membentuk tugas perkembangan yang harus dilalui oleh seseorang individu. Tentunya kondisi lingkungan akan mewarnai content dari Tugas Perkembangan, maka content khusus akan memberi kontribusi pada tugas perkembangan.

Mengingat tugas-tugas perkembangan sangat kompleks dan relatif berat bagi remaja, maka untuk dapat melaksanakan tugastugas tersebut dengan baik, remaja masih sangat membutuhkan bimbingan dan pengarahan supaya dapat mengambil langkah yang tepat sesuai dengan kondisinya. Di samping tugas-tugas perkembangan, remaja masih mempunyai kebutuhan-kebutuhan yang tentu saja menuntut pemenuhan secepatnya sesuai darah mudanya yang bergejolak. Kebutuhankebutuhan tersebut, menurut Edward, sebagaimana dikutip Hafsah,19adalah meliputi: (1) kebutuhan untuk mencapai sesuatu, (2) kebutuhan akan rasa superior, ingin menonjol, ingin terkenal, (3) kebutuhan untuk mendapatkan penghargaan, (4) kebutuhan akan keteraturan, (5) kebutuhan akan adanya kebebasan untuk menentukan sikap sesuai dengan kehendaknya, (6) kebutuhan untuk menciptakan hubungan persahabatan, (7) adanya keinginan ikut berempati, (8) kebutuhan mencari bantuan dan simpati, (9) keinginan menguasai tetapi tidak ingin dikuasai, (10) menganggap diri sendiri rendah, (11) adanya kesediaan untuk membantu orang 
lain, (12) kebutuhan adanya variasi dalam kehidupan, (13) adanya keuletan dalam melaksanakan tugas, (14) kebutuhan untuk betgaul dengan lawan jenis, dan (15) adanya sikap suka mengkritik orang lain 


\section{BAB V \\ PERKEMBANGAN KEMANDIRIAN PESERTA DIDIK}

\section{A. Kemandirian}

Perkembangan kemandirian merupakan masalah penting sepanjang rentang kehidupan manusia. Perkembangan kemandirian sangat dipengaruhi oleh perubahan-perubahan fisik, yang pada gilirannya dapat memicu terjadinya perubahan emosional, perubahan kognitif yang memberikan pemikiran logis tentang cara berpikir yang mendasari tingakah laku, serta perubahan nilai dalam peran sosial melalui pengasuhan orangtua dan aktivitas individu. Secara spesifik, masalah kemandirian menuntut suatu kesiapan individu, baik kesiapan fisik maupun emosional untuk mengatur, mengurus dan melakukan aktivitas atas tanggung jawabnya sendiri tanpa banyak menggantungkan diri pada orang lain.

Kemandirian muncul dan berfungsi ketika peserta didik menemukan diri pada posisi yang menuntut suatu tingkat kepercayaan diri. Menurut Steinberg (1993), kemandirian berbeda dengan tidak tergantung, karena tidak tergantung merupakan bagain untuk memperoleh kemandirian. Istilah "kemandirian" berasal dari kata dasar "diri" yang mendapat awalan "ke" dan ahkiran "an", kemudian membentuk satu kata keadaan atau kata benda. Karena kemandirian berasal dari kata dasar "diri", maka pembahasan mengenai kemandirian tidak bisa lepas dari pembahasan tentang perkembangan diri itu sendiri, yang dalam konsep Carl Rogers disebut dengan istilah self, karena diri itu merupakan inti dari kemandirian. Konsep yang sering digunakan atau berdekatan dengan kemandirian adalah autonomy.

Menurut Chaplin (2002), otonomi adalah kebebasan individu manusia dapat memilih, untuk menjadi kesatuan yang bisa memerintah, menguasai dan menentukan dirinya sendiri, sedangkan 
Seifert dan Hoffnung (1994) mendefinisikan otonomi atau kemandirian sebagai "the ability to govern and regulate one's own thoughts, feelings, and actions freely and responssibly while overcoming feelings of shame and doubt."
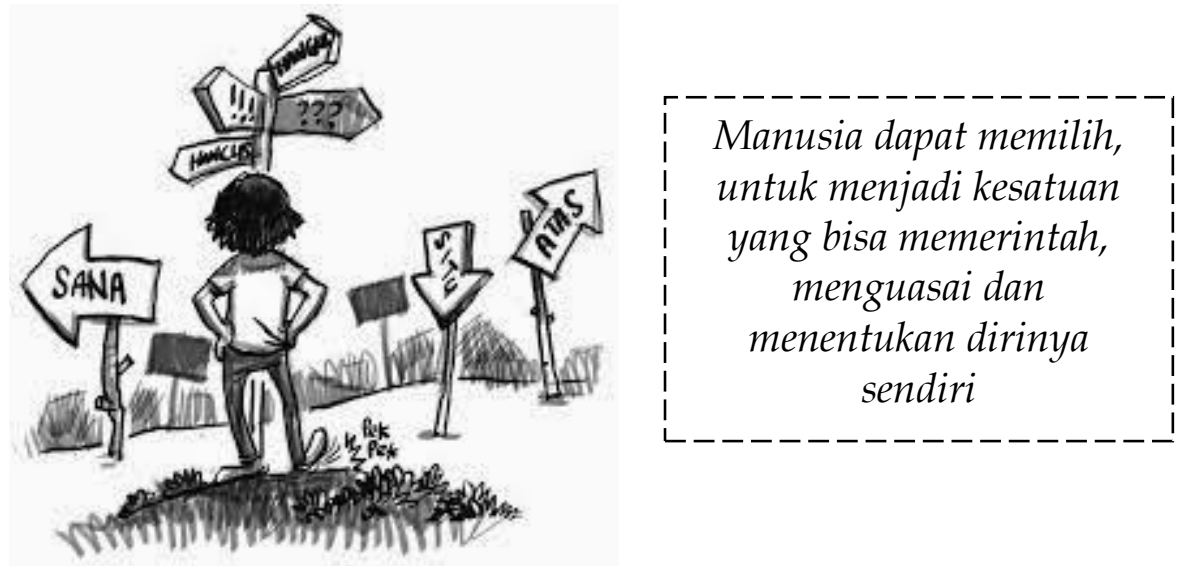

Gambar 11. Kemandirian Masa Remaja

Dengan demikian dapat dipahami bahwa kemandirian atau otonomi adalah kemampuan untuk mengendalikan dan mengatur pikiran, perasaan dan tindakan sendiri secara bebas serta berusaha sendiri untuk mengatasi perasaan-perasaan malu dan keragu-raguan. Erikson (dalam Monks, dkk, 1989), menyatakan kemandirian adalah usaha untuk melepaskan diri dari orangtua dengan maksud untuk menemukan dirinya melalui proses mancari identitas ego, yaitu merupakan perkembangan ke arah individulitas yang mantap dan berdiri sendiri. Kemandirian biasanya ditandai dengan kemampuan menentukan nasib sendiri, kreatif dan inisiatif, mengatur tingkah laku, bertanggung jawab, mampu menahan diri, membuat keputusankeputusan sendiri, serta mampu mengatasi masalah tanpa ada pengaruh dari orang lain. 
Kemandirian merupakan wujud suatu tindakan yang didorong oleh keinginan, inisiatif, dan tanggung jawab sendiri untuk menentukan dan mencari sumber belajar serta metode pembelajaran tanpa ada suruhan atau dorongan orang lain. Sikap mandiri siswa dalam belajar merupakan hal yang sangat penting dan perlu ditumbuh-kembangkan pada siswa sebagai peserta didik. Intelektualitas adalah perubahan yang positif dari sebuah kemandirian belajar yang siswa terapkan pada pembelajaran mereka sendiri. Selain itu Asrori (2009) mengungkapkan kebiasaan belajar yang kurang baik seperti baru belajar setelah menjelang ujian, membolos, mencontek, dan mencari bocoran soal ujian adalah dampak dari kurangnya kemandirian belajar dikalangan remaja seperti siswa.

Kemandirian merupakan suatu sikap otonomi di mana peserta didik secara relatif bebas dari pengaruh penilaian, pendapat dan keyakinan orang lain. Dengan otonomi tersebut, peserta didik diharapkan akan lebih bertanggung jawab terhadap dirinya sendiri. Secara singkat dapat disimpulkan bahwa kemandirian mengandung pengertian:

1. Suatu kondisi di mana seseorang memiliki hasrat bersaing untuk maju demi kebaikan dirinya sendiri.

2. Mampu mengambil keputusan dan inisiatif untuk mengatasi masalah yang dihadapi.

3. Memiliki kepercayaan diri dan melaksanakan tugas-tugasnya.

4. Bertanggung jawab atas apa yang dilakukannya.

\section{B. Bentuk-bentuk Kemandirian}

Robert Havighurst (1972) membedakan kemandirian atas tiga bentuk kemandirian, yaitu: 
1. Kemandirian emosional, yaitu kemampuan mengontrol emosi sendiri dan tidak tergantungnya kebutuhan emosi pada orang lain.

2. Kemandirian ekonomi, yaitu kemampuan mengatur ekonomi sendiri dan tidak tergantungnya kebutuhan ekonomi pada orang lain.

3. Kemampuan intelektual, yaitu kemampuan untuk mengatasi berbagai masalah yang dihadapi.

4. Kemamdirian sosial, yaitu kemampuan untuk mengadakan interaksi dengan orang lian dan tidak tergantung pada aksi orang lain.

Sementara itu, Steinberg (1993) membedakan karakteristik kemandirian atas tiga bentuk, yaitu: 1) kemandirian emosional (emotional autonomy); 2) kemandirian tingkah laku (behavioral autonomy); dan 3) kemandirian nilai (value autonomy). Lengkapnya, Steinberg menulis:

The first emotional autonomy-that aspect of independence related to changes in the individual's close relationships, especially with parent. The second behavioral autonomy-the capacity to make independent decisions and follow through with them. The third characterization involves an aspect of independence referred to as value autonomy-wich is more than simply being able to resist pressures to go along with the demands of other; it means having a set a principles about right and wrong, about what is important and what is not.

Kutipan di atas menunjukkan karakteristik dari ketiga aspek kemandirian, yaitu:

1. Kemandirian emosional, yakni aspek kemandirian yang menyatakan perubahan kedekatan hubungan emosional antar individu, seperti hubungan emosional peserta didik dengan guru atau dengan orangtuanya. 
2. Kemandirian tingkah laku, yakni suatu kemampuan untuk membuat keputusan-keputusan tanpa tergantung pada orang lain dan melakukannya secara bertanggung jawab.

3. Kemandirian nilai, yakni kemampuan memaknai seperangkat prinsip tentang benar dan salah, tentang apa yang penting dan apa yang tidak penting.

\section{Tingkatan dan Karakteristik Kemandirian}

Sebagai suatu dimensi psikologis yang kompleks, kemandirian dalam perkembangannya memiliki tingkatan-tingkatan. Perkembangan kemandirian seseorang berlangsung secara bertahap sesuai dengan tingakt perkembangan kemandirian tersebut. Lovinger (Kartadinata, 1988), mengemukakan tingakatan kemandirian dan karakteristiknya, yaitu:

1. Tingkat pertama, adalah tingkat impulsif. Ciri-cirinya:

a. Peduli terhadap kontrol dan keuntungan yang dapat diperoleh dari interaksinya dengan orang lain.

b. Mengikuti aturan secara spontanistik dan hedonistik.

c. Berpikir tidak logis dan tertegunpada cara berpikir tertentu (stereotype).

d. Cenderung melihat kehidupan sebagai zero-sum games.

e. Cenderung menyalahkan dan mencela orang lain serta lingkungannya.

2. Tingkat kedua, adalah tingkat konformistik. Ciri-cirinya:

a. Peduli terhadap penampilan diri dan penerimaan sosial.

b. Cenderung berpikir stereotype dan klise.

c. Peduli akan konformitas terhadap aturan eksternal.

d. Bertindak dengan motif dangkal untuk memperoleh pujian.

e. Menyamakan diri dalam ekspresi emosi dan kurangnya introspeksi. 
f. Perbedaan kelompok didasarkan atas ciri-ciri eksternal.

g. Takut tidak diterima kelompok.

h. Tidak sensitif terhadap keindividualan.

i. Merasa berdosa jika melanggar aturan.

3. Tingkat ketiga, adalah tingkat sadar diri

a. Mampu berpikir alternatif.

b. Melihat harapan dan berbagai kemugkinan dalam situasi.

c. Peduli untuk mengambil manfaat dari kesempatan yang ada.

d. Menekankan pada pentingnya memecahkan masalah.

e. Memikirkan cara hidup.

f. Penyesuian terhadap situasi dan peranan.

4. Tingkat keempat, adalah tingkat saksama (conscientious). Ciricirinya:

a. Bertindak atas dasar nilai-nilai internal.

b. Mamapu melihat diri sebagai pembuat pilihan dan pelaku tindakan.

c. Mampu melihat keragaman emosi, motif, dan perspektif diri sendiri maupun orang lain.

d. Sadar akan tanggung jawab.

e. Mampu melakukan kritik dan penilaian diri.

f. Peduli akan hubungan mutualistik.

g. Memiliki tujuan jangka panjang.

h. Cenderung melihat peristiwa dalam konteks sosial.

i. Berpikir lebih kompleks dan atas dasar pola analitis.

5. Tingkat kelima, adalah tingkat individualitas. Ciri-cirinya:

a. Penigkatan kesadaran individualitas.

b. Kesadaran akan konflik emosional antara kemandirian dan ketergantungan.

c. Menjadi lebih toleran terhadap diri sendiri dan orang lian.

d. Mengenal ekstensi perbedaan individual. 
e. Mampu bersikap toleran terhadap pertentangan dalam kehidupan.

f. Membedakan kehidupan internal dengan kehidupan luar dirinya.

g. Mengenal kompleksitas diri.

h. Peduli akan perkembangan dan masalah-masalah sosial.

6. Tingkat keenam, adalah tingkat mandiri. Ciri-cirinya:

a. Memiliki pandangan hidup sebagai suatu keseluruhan.

b. Cenderung bersikap realistik dan objektif terhadap diri sendiri dan orang lain.

c. Peduli terhadap pemahaman abstrak, seperti keadilan sosial.

d. Mampu mengintegrasikan nilai-nilai yang bertentangan.

e. Toleran terhadap ambiguitas.

f. Peduli akan pemenuhan diri (self-fulfilment).

g. Ada keberanian untuk menyelesaikan konflik internal.

h. Responssif terhadap kemandirian orang lain.

i. Sadar akan adanya saling ketergantungan dengan orang lain.

j. Mampu mengekspresikan perasaan dengan penuh keyakinan dan keceriaan.

\section{Pentingnya Kemandirian Bagi Peserta Didik}

Pentingnya kemandirian bagi peserta didik, dapat dilihat dari situasi kompleksitas kehidupan dewasa ini, yang secara langsung atau tidak langsung memengaruhi kehidupan peserta didik. Pengaruh kompleksitas kehidupan terhadap peserta didik terlihat dari berbagai fenomenal yang sangat membutukan perhatian dunia pendidikan, seperti perkelahian antar pelajar, penyalagunaan obat dan alkohol, perilaku agresif, dan berbagai perilaku menyimpang yang sudah mengarahkan pada tindak kriminal. Dalam konteks proses belajar, 
terlihat adanya fenomenal peserta didik yang kurang mandiri dalam belajar, yang dapat menimbulkan gangguan mental setelah memasuki pendidikan lanjutan, kebiasaan belajar yang kurang baik (seperti tidak betah belajr lama atau belajar hanya menjelang ujian, membolos, menyontek, dan mencari bocoran soal-soal ujian).

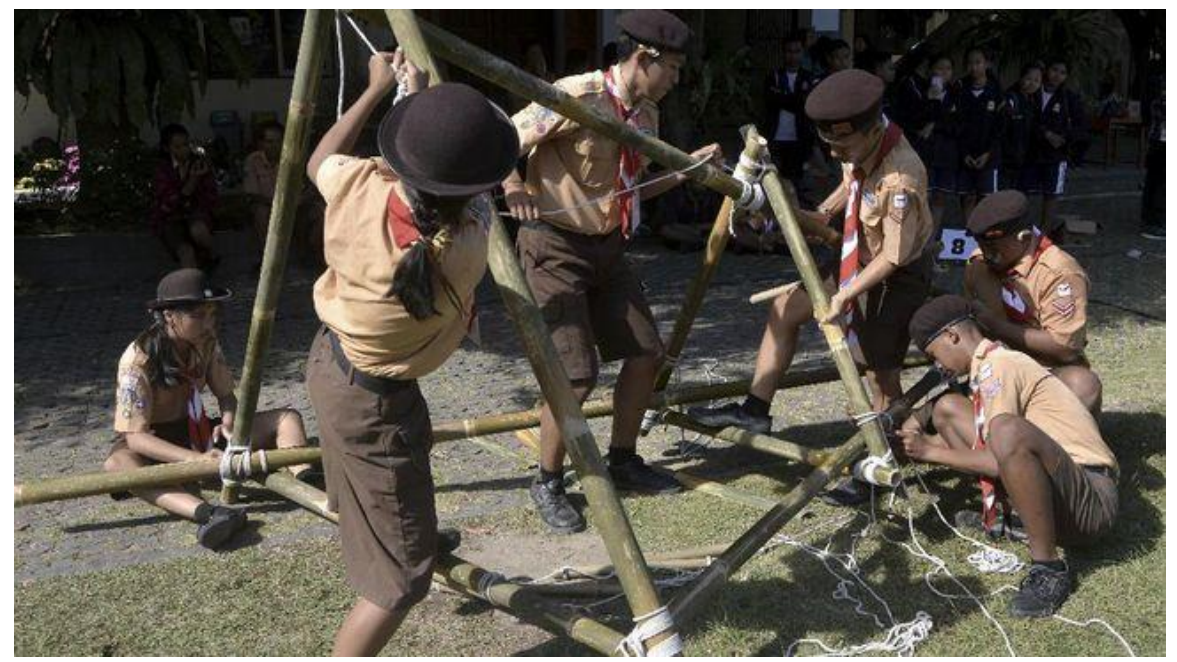

Gambar 12. Kemandirian Peserta Didik

Contoh kegiatan-kegiatan di atas, menuntut dunia pendidikan untuk segera mengembangkan kemandirian peserta didik. Sunaryo Kartadinata (1988) menyebutkan beberapa gejala yang berhubungan dengan permasalahan kemandirian yang perlu mendapat perhatian dunia pendidikan, yaitu:

1. Ketergantungan disiplin kepada kontrol luar dan bukan karena niat sendiri yang ikhlas. Perilaku seperti ini akan mengarah pada perilaku formalistik, ritualistik dan tidak konsisten, yang pada gilirannya akan menghambat pembentukan etos kerja dan etos 
kehidupan yang mapan sebagai salah satu ciri dari kualitas sumber daya dan kemandirian manusia.

2. Sikap tidak peduli terhadap lingkungan hidup. Manusia mendiri bukanlah manusia yang lepas dari lingkungannya, melainkan manusia yang bertransenden terhadap lingkungannya. Ketidakpedulian terhadap lingkungan hidup merupakan gejala perilaku implusif, yang menunjukkan bahwa kemandirian masyarakat masih rendah.

3. Sikap hidup konformistis tanpa pemahaman dan konformistik dengan mengorbankan prinsip. Mitos bahwa segala sesuatunya bisa diatur yang berkembang dalam masyarakat menunjukkan adanya ketidakjujuran dalam berpikir dan bertindak serta kemandirian yang masih rendah.

Gejala-gejala tersebut merupakan bagian kendala utama dalam mempersiapkan individu-individu yang mengerangi kehidupan masa mendatang yang semakin kompleks dan penuh tantangan. Oleh sebab itu, perkembangan kemandirian peserta didik menuju ke arah kesempurnaan menjadi sangat penting untuk dilakukan secara serius, sistematis dan terprogram.

Kemandirian adalah kecakapan yang berkembang sepanjang rentang kehidupan individu, ang sangat dipengaruhi oleh faktor-faktor pengalaman dan pendidikan. Oleh sebab itu, pendidikan di sekolah perlu melakukan upaya-upaya pengembangan kemandirian peserta didik, diantaranya:

1. Mengembangkan proses belajar mengajar yang demokratis, yang memungkinkan anak merasa dihargai.

2. Mendorong anak untuk berpartisipasi aktif dalam pengambilan keputusan dan dalam berbagai kegiatan sekolah.

3. Memberi kebebasan kepada anak untuk mengeksplorasi lingkungan, mendorong rasa ingin tahu mereka. 
4. Penerimaan positif tanpa syarat kelebihan dan kekurangan anak, tidak membeda-bedakan anak yang satu dengan yang lain.

5. Menjalin hubungan yang harmonis dan akrab dengan anak. 


\section{BAB V \\ PERKEMBANGAN SPIRITUAL PESERTA DIDIK}

\section{A. Pengertian Spiritualitas}

Kata spiritualitas berasal dari bahasa Inggris yaitu "spirituality", kata dasarnya "spirit" yang berarti: "roh, jiwa, semangat" (Echols \& Shadily, 1997). Kata spirit sendiri berasal dari kata Latin "spiritus" yang berarti: "Iuas atau dalam (breath), keteguhan hati atau keyakinan (courage), energi atau semangat (vigor), dan kehidupan (Ingersoll, 1994). Kata sifat spiritual berasal dari kata Latin spiritualis yang berarti "of the spirit" (kerohanian).

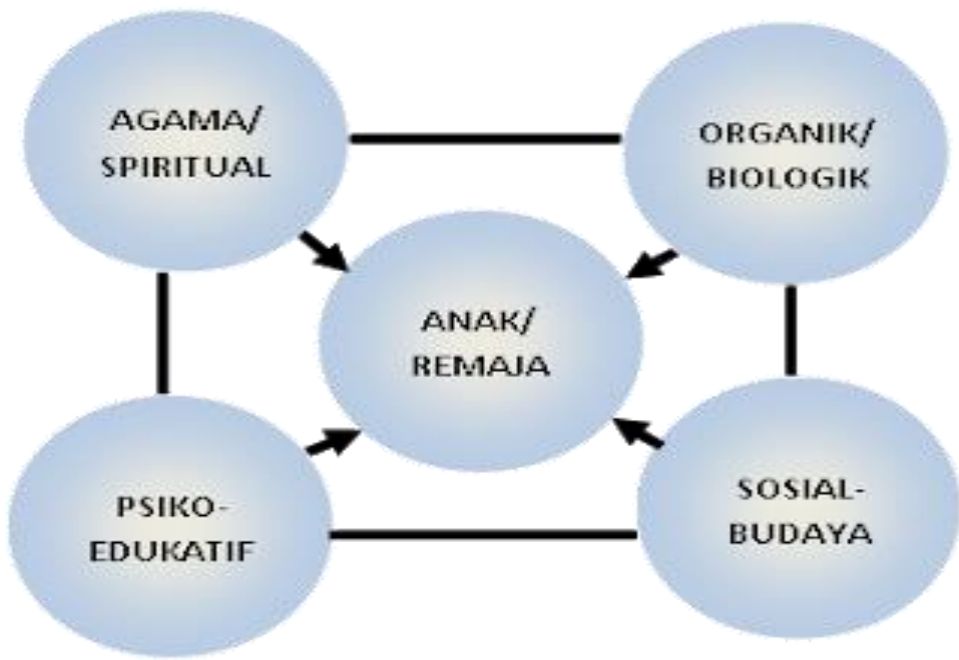

Gambar 13. Dimensi Tumbuh Kembang Spiritual Remaja

Ingersoll (1994) mengartikan spiritualtas sebagai wujud dari karakter spiritual, kualitas atau sifat dasar. Belakangan, definisi tentang spiritualitas meliputi komunikasi dengan Tuhan (Fox, 1983) dan upaya seseorang untuk bersatu dengan Tuhan (Magill \& McGreal, 
1994). Tillich (1959) menulis bahwa spiritualitas merupakan persoalan pokok manusia dan pemberi makna substansi dari kebudayaan.

Witmer (1989) mendefinisikan spiritualitas sebagai suatu kepercayaan akan adanya suatu kekuatan atau suatu yang lebih agung dari diri sendiri. Bollinger (1969) menggambarkan kebutuhan spiritual sebagai kebutuhan terdalam diri seseorang yang apabila terpenuhi individu akan menemukan identitas dan makna hidup yang penuh arti. Booth (1992) menjelaskan bahwa spiritualitas adalah suatu sikap hidup yang memberi penekanan pada energi, pilihan kreatif dan kekuatan penuh bagi kehidupan serta menekankan pada upaya penyatuan diri dengan suatu kekuatan yang lebih besar dari individual, suatu cocreatorship dengan Tuhan. May (1988) menyebutkan bahwa spirit manusia "is the source of our yearning as well as our very life." Schaef (1992) menyamakan spiritualitas dengan ketenangan hati (soriety) dan hidup dalam proses (living in process), yang diartikan sebagai perjalanan, proses dan kelangsungan hidup kita.

Menurut Hasan (2006), spiritualitas memiliki ruang lingkup dan makna pribadi yang luas, Hanya saja, spiritualitas mungkin dapat dimengerti dengan membahas kata kunci yang sering muncul ketika orang-orang menggambarkan arti spiritualitas bagi mereka. Dengan mengutip hasil penelitian Martsolf dan Mickley, Aliah B. Purwakania Hasan menyebutkan beberapa kata kunci yang bisa dipertimbangkan, yaitu:

1. Meaning (makna). Makna merupakan sesuatu yang signifikan dalam kehidupan manusia, merasakan situasi, memiliki dan mengarah pada suatu tujuan.

2. Values (nilai-nilai). Nilai-nilai adalah kepercayaan, standar dan etika yang dihargai. 
3. Transcendence (transendensi). Transendensi merupakan pengalaman, kesadaran dan penghargaan terhadap dimensi transendental bagi kehidupan di atas diri seseorang.

4. Connecting (bersambung). Bersambung adalah meningkatkan kesadaran terhadap hubungan dengan diri sendiri, orang lain, tuhan dan alam.

5. Becoming (menjadi). Menjadi adalah membuka kehidupan yang menuntut refleksi dan pengalaman, termasuk siapa seseorang dan bagaimana seseorang mengetahui.

\section{B. Spiritualitas dan Riligiusitas}

Untuk lebih memahami pengertian tentang spiritualitas, perlu juga diuraikan tentang hubungannya dengan religiusitas. Ini adalah penting, karena belakangan berkembang paham yang menganggap spiritualitas lebih penting dari agama. Pandangan ini berkembang terutama sejak John Naisbitt dan Aburdene, dua futurolog kenamaan mengeluarkan semboyan yang berbunyi: "Spirituality, Yes, Organized Religion, No."

Menurut estimasi Naisbitt dan Aburdene, masyarakat masa depan akan cenderung mengabaikan agama dan lebih mendalami spiritualitas. Karena itu, perbedaan keduanya akan semakin tajam, meskipun keduanya sama-sama berkaitan dengan kebutuhan manusia yang paling mendasar. Menurut kedua futurolog tersebut, berdasarkan hasil-hasil pengumpulan pendapat, ada indikasi menaiknya spiritualitas di kalangan masyarakat Amerika, lebih tinggi dari masa-masa sebelumnya. Sebagian besar mereka percaya bahwa "Tuhan adalah kekuatan spiritual yang positif dan aktif," meskipun gejala itu disertai dengan menurunnya peran agama-agama formal. 


\section{Produktivitas}

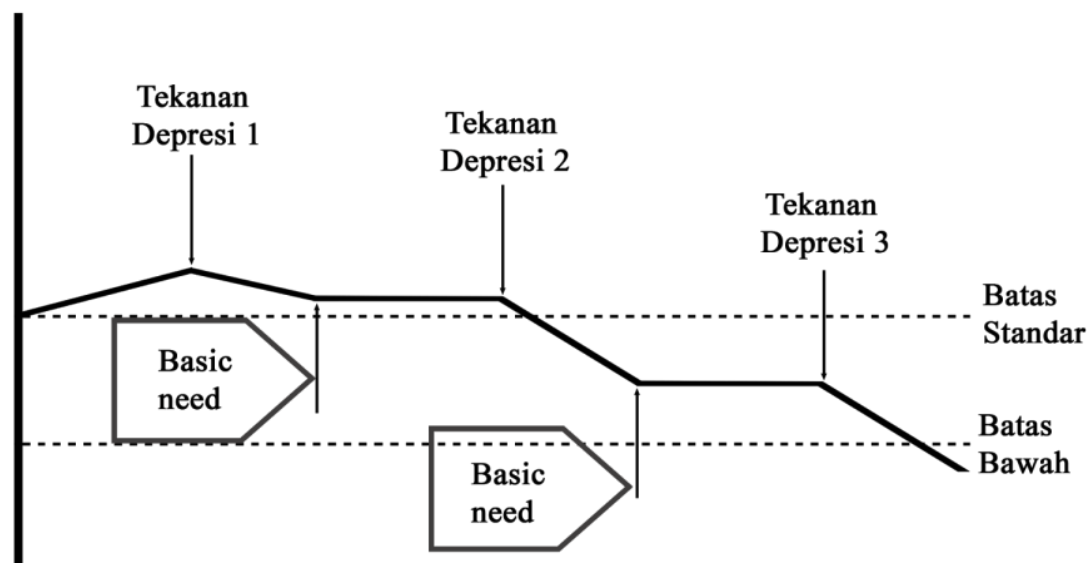

Kalangan muda yang terpelajar di sekolah-sekolah tinggi pertama-tama bersikap sangat kritis terhadap agama-agama formal. Mereka menilai bahwa gereja dan sinagog "sibuk dengan masalahmasalah keorganisasian, dengan mengesampingkan isu-isu theologis dan spiritual." Karena itu kata Naisbitt dan Aburdene, mereka kaum muda itu bukan manusia "beragama" (religious), melainkan "berkeruhanian" (spiritual).

Peserta didik adalah semua individu yang menjadi audiens dalam suatu lingkup pembelajaran. Biasanya penyebutan peserta didik ini mengikuti skup/ruang lingkup dimana pembelajaran dilaksanakan, diantaranya : peserta didik untuk jenjang pendidikan dasar dan menengah, mahapeserta didik untuk jenjang pendidikan tinggi, dan peserta pelatihan untuk diklat. Peserta didik adalah masukan mentah (raw input) dalam sebuah proses pembelajaran yang harus dithreat agar output dan outcomesnya sesuai dengan yang dicanangkan 
institusi (khususnya) dan dunia pendidikan Indonesia pada umumnya. Menurut Udin S. Winataputra (2007) Pasal 1 butir 4 UU Nomor 20 tahun 2003 tentang Sisdiknas, peserta didik adalah anggota masyarakat yang berusaha mengembangkan potensi diri melalui proses pembelajaran yang trsedia pada jalur, jenjang dan pendidikan tertentu. Peserta didik atau peserta didik merupakan subyek utama dalam pembelajaran dalam usaha pencapaian tujuan pembelajaran yang telah dibuat sebagai acuan kegiatan belajar-mengajar.

Agama memang tidak mudah untuk didefinisikan secara tepat, karena agama mengambil bentuk bermacam-macam di antara sukusuku dan bangsa-bangsa di dunia ini. Secara etimologi, religion (agama) berasal dari bahasa latin religio, yang berarti suatu hubungan antara manusia dengan Tuhan. Istilah Latin ini merupakan transformasi dari kata religare, yang berarti to bind together (menyatukan). Berdasarkan akar kata ini, Ingersoll mendefinisikan religion sebagai: "an expression of beliefs in conduct and ritual, the basis for a medium of organized worship and fellowship becomes apparent."

Berbeda dengan agama, spiritualitas lebih banyak melihat aspek dalam bentuk lubuk hati, riak getaranhati nurani pribadi, sikap personal yang bagi banyak orang lain merupakan misteri, karena intimitas jiwa. Dalam hal ini, spiritualitas mencakup citra rasa totalitas kedalam pribadi manusia. Berdasarkan pemahaman ini, spiritualitas tampak lebih ekstrim, lebih dalam dari agama yang cenderung lebih eksoterik formal dan kaku. Dalam hal ini Ingersoll (1994) menulis:

"...two distinction can be drawn between spirituality and religion. First, religion's provision of a social identity may not necessarily be provided in a personal spirituality. Second, due to the corporate nature of religion there may be fewer variations in its stipulated behavioral correlates than those found in personal spiritualities. 
Kutipan di atas memperlihatkan bahwa Ingersoll membedakan secara tajam antara agama dan spiritualitas. Untuk lebih memberi pemahaman tentang istilah spiritualitas dan religiusitas, ada baiknya dikutip penjelasan Aliah B. Purwakania Hasan (2006), seorang ahli psikolog dari Universitas Indonesia (UI)

Istilah spiritual dan religius sering kali dianggap sama, namun banyak pakar yang menyatakan keberatannya jika kedua istilah ini dipergunakan saling silang. Spiritualitas kehidupan adalah inti keberaadaan dari kehidupan. Spiritualitas adalah kesadaran tentang diri, dan kesadaran individu tentang asal, tujuan, dan nasib. Agama adalah kebenaran mutlak dari kehidupan yang memiliki manifestasi fisik di atas dunia. Agama merupakan serangkaian praktik perilaku tertentu yang dihubungkan dengan kepercayaan yang dinyatakan oleh institusi tertentu dan dianut oleh anggota-anggotanya. Agama memilik kesaksian iman, komunitas dan kode etik. Dengan kata lain, spiritualitas memberikan jawaban siapa dan apa seseorang itu (keberadaan dan kesadaran), sedangkan agama memberikan jawaban apa yang harus dikerjakan seseorang (perilaku atau tindakan). Seseorang bisa saja mengikuti agama tertentu, namun tetap memiliki spiritualitas. Orang-orang juga dapat menganut agama yang sama, namun belum tentu memiliki jalan atau tingkat spiritualitas yang sama, namun belum tentu meiliki jalan atau tingkat spiritualitas yang sama. Perbedaan juga harus dibuat antara spiritualitas yang berbeda dengan agama dan spiritualitas dalam agama.

Meskipun keduanya (agama dan spiritualitas) terlanjur dipisahkan, namun untuk pemenuhan makna hidup manusia yang sejati, nampaknya harus ada upaya pemaduan antara spiritualitas dan agama. "Agama memang tidak sama dengan spiritualitas, namun agama merupakan bentuk spiritualitas yang hidup dalam peradaban", dengan pernyataan William Irwin Thompson (dalam Aliah B. 
Purwakania Hasan, 2006). Bahkan Mickley et al (dalam Achir Yani S. Hamid, 2000), menyebutkan bahwa agama merupakan salah satu dimensi dari spiritualitas, di samping dimensi eksistensial. Dimensi eksistensial dari spiritualitas berfokus pada tujuan dan makna hidup, sedangkan dimensi agama dari spiritualitas berfokus pada hubungan seseorang dengan Tuhan Yang Maha Penguasa. Singkatnya, agama bisa dikatakan tidak sama dengan apiritualitas, tetapi keduanya tidak bisa dipisahkan. Betapapun, agama tanpa spiritualitas adalah kering, dan spiritualitas tanpa agama lumpuh. Atau seperti apa yang dikemukakan oleh Nasr, "mengembangkan spiritualitas tanpa agama seperti menanam pohon di atas angin, tidak akan tumbuh sempurna."

Dalam dua dekade belakangan ini, isu-isu seputar spiritualitas banyak mendapat perhatian dalam studi-studi sains sosial. Wacana tentang spiritualitas semakin meningkat, terutama sejak John Naisbitt dan Patricia Aburdene memandang zaman sekarang ini sebagai "New Age" (Zaman Baru) yang dicirikan dengan pesatnya perhatian manusia modern terhadap dunia spiritual. Bahkan slogan "Spirituality, Yes; Organized Religion, No", yang ditulis oleh kedua futurolog ini, telah menjadi petunjuk betapa besarnya perhatian manusia Barat khususnya terhadap dunia spiritual, khususnya terhadap spiritualitas Timur.

Terjadinya peningkatan penggunaan kata spiritualitas dalam disiplin akademis dan literatur-literatur populer, telah menjelmakan suatu konsep spiritualitas untuk menggambarkan bermacam-macam kapasitas. Meskipun literatur dalam ilmu-ilmu sosial lainnya seperti sosiologi (morberg, 1979) dan teologi kontemporer (Schneiders, 1989) telah menunjukkan adanya peningkatan perhatian dalam menjelaskan konsep spiritualitas, namun dalam bidang psikologi belum terlihat adanya riset yang mendalam yang bisa diterima sebagai subjek teoritis atau klinis yang penting. Bahkan menurut Ingersoll (2004), dalam 
literatur terapeutik masalah spiritualitas cenderung diabaikan. Setidaknya terdapat dua alasan mengapa spiritualitas kurang mendapat perhatian dalam kajian-kajian psikologi umumnya, yaitu: pertama, sebagaimana dinyatakan oleh Shafranske dan Gorsuch (1984), relatif kurangnya perhatian terhadap studi tentang spiritual dalam psikologi mungkin dapat dilacak pada akar historis profesi tersebut yang berusaha memisahkan diri dari disiplin filosofis nonempirik. Hal ini diperburuk oleh fakta bahwa konsep spiritual sendiri bersifat dinamis dan secara historis telah mengalami banyak perubahan bentuk dalam kaitannya dengan institusi religius, struktur politik, dan pergerakan sosial.

Kedua, dalam hubungan dengan praktik klinis, diskusi tentang spiritualitas yang terjadi dalam konseling sering berhadapan dengan kenyataan bahwa kerangka acuan yang digunakan therapist sering bertentangan dengan apa yang dialami oleh klien. Meskipun demikian, para profeional dalam bidang psikologi mengambil secara serius Riset Bergin's (1980) mengenal dampak penilaian konselor dalam psikoterapi, suatu usaha bertanggung jawab yang harus dilakukan untuk menjelaskan bagaimana pemahaman tentang spiritual memengaruhi penilaian tersebut. Seperti apa yang dikemukakan oleh Tjeltveit (1989) bahwa kegagalan dalam memahami semua model manusia (termasuk model spiritual) merupakan suatu bentuk pengabaian resiko aspek kunci dari pengalaman dan perilaku manusia. Sayangnya, problem yang banyak muncul dari data-data yang ada adalah di sekitar konsep yang telah dinyatakan dalam suatu konseptual, versus kuantitatif, bentuk keragu-raguan ilmiah yang terus dipromosikan.

\section{Spiritualitas dalam Psikologi Humanistik}


Psikologi humanistik muncul pada pertengahan abad ke-20 sebagai reaksi terhadap teori psikodinamik dan behavioristik. Keduanya dianggap telah mereduksi manusia sebagai mesin atau makhluk rendah. Psikoanalisis berkutat pada insting-insting hewani dan memahami manusia dari perilaku pasien. Para teoritikus humanistik, seperti Carl Rogers (1902-1987) dan Abraham Maslow (1908-1970) menyakini bahwa tingkah laku manusia tidak dapat dijelaskan sebagai hasil dari konflik-konflik yang tidak disadari maupun sebagai hasil pengkondisian (conditioning) yang sederhana. Teori ini menyiratkan penolakan terhadap pendapat bahwa tingkah laku manusia semata-mata ditentukan oleh faktor di luar dirinya. Sebaliknya, teori ini melihat manusia sebagai aktor dalam drama kehidupan, bukan reaktor terhadap insting atau tekanan lingkungan. Teori ini berfokus pada pentingnya pengalaman disadari yang bersifat subjektif dan self-direction.

Aliran humanistik berhubungan erat dengan aliran filosofis Eropa yang disebut sebagai "eksistensialisme". Para eksistensialis, seperti filsuf Martin Heidegger (1889-1976) dan Jean-Paul Sartre (1905-1980), memfokuskan perhatian pada pencarian arti dan pentingnya pilihan pada eksistensi manusia. Para eksistensialis juga meyakini bahwa kemanusiaan kita membuat kita bertanggung jawab atas arah yang akan diambil dalam kehidupan kita.

Berbeda dengan psikoanalisis yang memandang buruk hakikat manusia, dan psikologi behavior yang memandang netral, psikologi humanistik berasumsi bahwa manusia pada dasarnya memiliki potensi-potensi yang baik, minimal lebih banyakbaiknya daripada buruknya. Spikologi humanistik memusatkan perhatian untuk menelaah kualitas-kualitas insani, yakni sifat-sifat dan kemampuan khusus manusia yang terpatri pada eksistensinya, seperti kemampuan abstraksi, daya analisis dan sintesis, imajinasi, kreativitas, kebebasan 
berkehendak, tanggung jawab, aktualisasi diri, makna hidup, pengembangan pribadi, humor, sikap etis dan rasa estetika. Kualitaskualitas ini benar-benar khas insani dan tidak dimiliki oleh makhluk lain, terutama hewan. Ini jelas berbeda dari sasaran studi psikoanalisis dan psikologi behavior, yang menekankan pada insting dan dorongandorongan serta pola-pola perilaku manusia hasil rekayasa dan proses pembisaan yang juga terdapat pada hewan. Di samping itu, psikologi humanistik memandang manusia sebagai makhluk yang memiliki otoritas atas kehidupan dirinya sendiri. Asumsi ini menunjukkan bahwa manusia adalah makhluk yang sadar, mandiri, pelaku aktif yang dapat menentukan hampir segalanya. la adalah makhluk dengan julukan the self determining being yang mampu sepenuhnya menentukan tujuan-tujuan yang paling diinginkannya dan cara-cara mencapai tujuan itu yang dianggapnya paling tepat. 
Para teoritikus humanistik mempertahankan bahwa manusia memiliki kecenderungan bawaan untuk melakukan self-actualization untuk berjuang menjadi apa yang mereka mampu. Setiap manusia memiliki serangkaian perangai dan bakat-bakat yang mendasari perasaan dan kebutuhan individual serta memberikan perspektif yang unik dalam hidup kita. Meskipun pada akhirnya setiap manusia akan mati, namun masing-masing dapat mengisi kehidupan dengan penuh arti dan bertujuan apabila kita mengenali dan menerima kebutuhan dan perasaan terdalam kita. Kita hidup secara autentik. Kesadaran diri terhadap perasaan-perasaan autentik dan pengalaman subjektif dapat membantu kita untik membuat pilihan-pilihan yang lebih bermakna.

Viktor Frankl adalah salah satu seorang tokoh psokologi humanistik yang sangat mempercayai dan banyak mempelajari fenomena makna hidup, kehendak untuk hidup bermakna dan bagaimana mengembangkan makna hidup. Perhatiannya yang besar terhadap fenomena makna hidup (the meaning of life) ini kemudian melahirkan sebuah aliran psikologi/psikiatri yang dikenal dengan Logoterapi. Sesuai dengan akar kata "logos" yang dalam bahasa Yunani berarti "meaning" (makna) dan juga "spirituality" (kerohanian), maka logoterapi merupakan aliran psikologi yang mengakui adanya dimensi kerohanian atau spiritualitas di samping dimensi-dimensi ragawi, kejiwaan dan lingkungan sosial budaya. Frankl beranggapan bahwa keinginan yang paling fundamental dari manusia adalah keinginan untuk memperoleh makna bagi eksistensinya, yang dalam bahasa Frankl disebut sebagai "kehendak akan makna (the will to meaning)." Jika kehendak akan makna itu tidak terpenuhi, maka individu akan mengalami frustrasi eksistensial, yang pada gilirannya dapat mengarahkan individu tersebut pada suatu bentuk neorosis yang ditandai dengan pelarian dari kebebasan dan tanggung jawab. Konsep dasar yang melandasi logoterapi adalah konsep tentang manusia 
sebagai makhluk spiritual yang keberadaannya memiliki makna instrinsik. Makna itu bersifat individual, dan manusia harus menemukannya dalam kehidupan (Misiak \& Sexton, 1988).

Logoterapi mengajarkan bahwa manusia harus dipandang sebagai kesatuan fisik, psikologis dan spiritual yang tidak terpisahkan. Dimensi spiritual, yang juga disebut Frankl sebagai noos merupakan dimensi yang menjadi sumber kekuatan dan kesehatan bagi manusia dalam melakukan terapi secara baik. Dimensi ini mengandung semua sifat khas manusia, seperti keinginan untuk memberi makna, orientasi tujuan, kreativitas, imajinasi, intuisi, keimanan, visi akan menjadi apa, kemampuan untuk mencintai di luar kecintaan yang visio-psikologis, kemampuan mendengarkan hati nurani di luar kendali superego, selera humor. Di dalamnya juga terkandung pembebasan diri dan transendensi diri atau kemampuan untuk menggapai orang yang kita cintai atau mengejar tujuan yang kita yakini. Di dalam dunia spirit, kita tidak dipandu, tetapi kita adalah pemandu, pengambil keputusan. Reservoir kesehatan ada pada setiap orang, apa pun agama dan keyakinannya. Kebanyakan dari reservoir ini terdapat di alam tak-sadar kita; adalah tugas seorang logoterapis untuk menyadarkankita akan perbendaharaan kesehatan spiritual ini (Farby, 1980).

Menurut Frankl, pengertian spiritual di sini sama sekali tidak mengandung konotasi agama, tetapi dimensi ini dianggap sebagai inti kemanusiaan dan merupakan sumber makana hidup dan potensi dari berbagai kemampuan dan sifat luhur manusia yang luar biasa yang sejauh ini terabaikan dari telaah psikologi.

\section{Spiritualitas dalam Psikologi Transpersonal}

Psikologi transpersonal sebenarnya merupakan kelanjutan atau lebih tepatnya pengembangan dari psikologi humanistik. Aliran psikologi ini disebut aliran keempat psikologi. S.I. Shapiro dan Denise 
H. Lajoie (1992) menggambarkan psikologi transpersonal sebagai berikut: "Transpersonal psychology is concerned with the study of humanitys highest potential, and with the recognation, understanding, and realization of unitive, spiritual, and trancendent states of consciousness."

Dari rumusan di atas terlihat dua unsur penting yang menjadi perhatian psikologis transpersonal, yaitu potensi-potensi luhur (the highest potentials) dan fenomena kesadaran (state of consciousness) manusia. Dengan perkataan lain, psikologi transpersonal memfokuskan perhatian pada dimensi spiritual dan pengalamanpengalaman rohaniah manusia.

The states of consciousness atau lebih populernya disebut the altered states of consciousness adalah pengalaman seseorang melewati batas-batas kesadaran biasa, seperti pengalamanpenganlaman alih dimensi, memasuki alam-alam kebatinan, kesatuan mistik, komunikasi batiniah, pengalaman meditasi, dan sebagainya. Demikian juga mengenai potensi-potensi luhur manusia menghasilkan telaah-telaah seperti altered states of consciousness, extra sensory perception, transendensi diri, kerohanian, potensi luhur dan paripurna, dimensi di atas alam kesadaran, pengalaman mistik, ekstasi, parapsikologi, paranormal, daya-daya batin, pengalaman spiritual dan praktek-praktek keagamaan di kawasan Timur dan berbagai belahan dunia lainnya, dan sebagainya.

Menurut pandangan psikoanalisis, tingkah laku manusia hanya dapat dipahami melalui pengkajian yang mendalam terhadap ketidaksadaran. Freud menyakini bahwa tingkah laku kita didorong oleh motif-motif di luar alam sadar kita dan konflik-konflik yang tidak kita sadari. Konflik-konflik itu didasari oleh hal-hal di seputar instinkinstink atau dorongan-dorongan seksual dan agresif primitif serta kebutuhan mempertahankan implus-implus primitif tersebut di luar 
kesadaran langsung kita. Jadi, menurut pandangan ini, tingkah laku manusia lebih ditentukan dan dikontrol oleh kekuatan psikologis, naluri-naluri irasional yang memang sudah ada sejak semula pada setiap diri individu.

Menurut teori behavioristik, orang terlibat di dalam tingkah laku tertentu karena mereka telah mempelajarinya, melalui pengalamanpengalaman terdahulu, menghubungkan tingkah laku tersebut dengan hadiah-hadiah. Orang menghentikan tingkah laku, mungkin karena tingkah laku tersebut belum diberi hadiah atau telah mendapat hukuman. Semua tingkah laku, baik bermanfaat ataupun merusak, merupakan tingkah laku yang dipelajari.

Dalam teori humanistik, manusia digambarkan secara optimistik dan penuh harapan. Di dalam diri manusia terdapat potensi-potensi untuk menjadi sehat dan tumbuh secara kreatif. Manusia digambarkan sebagai individu yang aktif, bertanggung jawab, mempunyai potensi kreatif, bebas, berorientasi ke depan.

Orang-orang yang mengalami pengalaman-pengalaman puncak merasa lebih terintegrasi, lebih bersatu dengan dunia, lebih menjadi raja atas diri mereka sendiri, lebih spontan, kurang menyadari ruang dan waktu, lebih cepat dan mudah menyerap sesuatu, dan sebagainya.

\section{E. Beberapa Konsep Acuan yang Relevan}

Penelitian dalam bidang Psikologi Perkembangan akhir-akhir ini difokuskan pada penjelasan mengenai terjadinya suatu proses perkembangan berupa rangkaian kejadian yang dialami oleh individu dengan lingkungan sosialnya. Dalam kehidupan seorang manusia, rentang kehidupan menjadi masalah yang penting dan patut dijadikan pijakan dalam upaya untuk mambahas suatu perilaku. Tingkah laku individu biasanya terkait dengan apa yang ingin dicapai olehnya, di 
pihak lain bukan saja pertimbangan dari dalam tetapi menyangkut juga harapan dan tuntutan dari orang lain terhadapnya.

Mengacu kepada konsep tentang tugas perkembangan, suatu proses kehidupan dilihat dari mulai seorang individu lahir sampai meninggal dunia. Pembahasan dilihat dari bagaimana seorang individu berusaha untuk memenuhi tugas perkembangan dari satu periode perkembangan ke periode perkembangan berikutnya dengan memecahkan berbagai macam permasalahan tugas perkembangan yang ditemui di setiap periode. Pada bahasan yang melibatkan periode perkembangan, terdapat periode-periode kritis dalam proses perkembangan. Periode kritis yang terjadi pada seorang individu biasanya terkait erat dengan bentuk tugas perkembangan yang diharapkan mampu untuk dilakukan oleh individu pada periode perkembangan tertentu. Havighurst (1953), membedakan dua kategori umum dari tugas-tugas perkembangan, yaitu:

1) Tugas-tugas yang muncul hanya pada suatu waktu tertentu dan harus dipenuhi pada waktu itu.

Contoh : belajar berjalan dan berbicara pada periode bayi.

2) Tugas-tugas yang bersifat sinambung, yaitu yang dijalani individu selama beberapa tahun dan bersifat jangka panjang.

Contoh : belajar berpartisipasi sebagai warga negara yang bertanggung jawab.

Menurut Havighurst (1953), merupakan hal yang penting bila anak dapat mengikuti dan berhasil dalam sebagian besar tugas-tugas pada waktu yang telah ditentukan. Sehubungan dengan tugas perkembangan, Havighurst (1953), mengemukakan suatu skema yang bersifat bio-sosio-psikologis. Hooker (1991) mengacu pada pendapat Havighurst yang mengemukakan bahwa pada dasarnya tugas-tugas perkembangan setiap periode perkembangan bersumber pada tiga hal yakni: 
1) Fungsi dan struktur biologis dari individu (dasar-dasar biologis), misalnya: belajar mengontrol pembuangan, belajar menerima perubahan seks yang bersifat fisik pada remaja, belajar bertingkah laku yang sesuai terhadap lawan jenis.

2) Rangsangan atau tuntutan dari masyarakat serta tugas-tugas yang timbul terutama dari tuntutan masyarakat, misalnya: belajar membaca dan menulis, belajar menghargai milik orang lain, belajar menerima tanggung jawab dalam mengerjakan bagian seseorang dalam kegiatan kelompok.

3) Nilai-nilai dan aspirasi-aspirasi pribadi dari individu. Contoh: tugas-tugas yang muncul pada masa remaja akhir, terutama bersumber dari nilai dan motif dari individu, misalnya dalam hal memilih pekerjaan dan bentuk keyakinan beragama.

Sebagai konsekuwensinya, daftar dari tugas perkembangan tidak akan sama untuk setiap budaya, dan item-item dalamdaftar yang diidentifikasikan dari tugas-tugas yang ada di lingkungan (budaya) akan tejelaskan oleh tingkat keberhasilan individu dalam mencapai tugas perkembangannya. Havighurst mengakui deskripsi dari tugastugas yang dihasilkannya berdasarkan pada "nilai-nilai budaya demokratis pada masyarakat Amerika dari kelas menengah, dengan beberapa usaha untuk menampilkan hasil yang bervariasi (1953). Huvighurst merasakan bahawa dalam menggunakan pendekatan tugas perkembangan bagi pendidikan anak-anak, akan lebih berguna jika dapat membuat enam sampai dengan sepuluh tugas untuk tiap tahap perkembangan. Pada usia remaja terdapat pula tugas-tugas perkembangan tertentu yang harus dipenuhi oleh individu. Konopka, 1973 (dalam Pikunas, 1976; Ingersol, 1989), secara umum membagi masa remaja menjadi tiga bagian, yaitu:

1) Masa remaja awal (12-15 tahun) 
Pada masa ini individu mulai meningkatkan peran sebagai anakanak dan berusaha mengembangkan diri sebagai inidivid yang unik dan tidak tergantung ada orang tua. Fokus dari tahap ini adalah penerimaan terhadap bentuk dan kondisi fisik serta adanya konformitas yang kuat dengan teman sebaya.

2) Masa remaja pertengahan (15-19)

Masa ini ditandai dengan berkembangnya kemampuan berpikir yang baru. Pada masa ini teman sebaya masih berperan penting namun individu sudah lebih mampu mengarahkan diri sendiri (self directed). Remaja juga mulai mengembangkan kematangan tingkah laku, belajar mengendalikan impulsivitas, dan membuat keputusan-keputusan awal yang berkaitan dengan sekolah dan pekerjaan yang kelak ingin ia capai. Selain itu penerimaan dari lawan jenis menjadi penting bagi individu.

3) Masa remaja akhir (19-22)

Masa ini ditandai oleh persiapan akhir untuk memasuki peranperan orang dewasa. Remaja pada masa ini memiliki keinginan yang kuat untuk diterima dalam kelompok teman sebaya dan orang dewasa. Pada tahap ini remaja menjadi lebih matang.

Dalam konteks perkembangan manusia, tentu saja tindakan dari seorang individu perlu dikaji, tidak hnaya dari rentang usia namun sejauh mana lingkungan akan berpengaruh pada tingkah laku seorang individu. Bahasan mengenai apa yang akan dan apa yang seharusnya dilakukan oleh seorang individu, disebut tugas perkembangan (Havighurst, 1972).

Dalam upaya membahas pengaruh lingkungan perkembangan, perlu diketahui terlebih dahulu definisi dari lingkungan. Bronfenbrenner (1979) memandang lingkungan dari sudut pandang ekologi dan berpendapat bahwasannya lingkungan sebagai suatu rangkaian sistem sosial mempunyai pengaruh langsung yang berbeda 
terhadap perkembangan anak. Pengaruh yang berperan langsung terhadap perkembangan anak adalah yang disebut sistem mikro, dapat berupa hubungan tatap muka seperti interaksi antara orang tua dengan anak atau interaksi antara guru dengan anak. Perkembangan manusia merupakan hasil interaksi antara manusia yang berkembang dengan lingkungannya. Perkembangan tersebut berupa perubahan dalam cara seseorang mengamati dan menghadapi lingkungan.

Bronfenbrenner (1979), dengan teori ekologi dari tingkah laku, lebih menekankan pada lingkungan sosial dengan sistem mikro, sistem meso, sistem ekso, dan sistem makro dalam mempelajari pengaruh lingkungan terhadap perkembangan. Konsep mengenai lingkungan dari Bronfenbrenner ini berdasarkan pada teori Lewin (Bronfenbrenner, 1979) mengenai life space. Menurut Lewin, lingkungan yang relevan untuk mengerti tingkah laku dan perkembangan bukanlah apa yang tampak, yaitu dunia objektif, tetapi lingkungan yang muncul dalam pikiran manusia. Dengan perkataan lain, Lewin lebih memfokuskan pada cara bagaimana lingkungan itu diamati oleh manusia yang berinteraksi di dalam dan dengan lingkungan tersebut. Terdapat sejumlah tuntutan adaptif yang normatif diajukan, secara khusus harus dihadapi oleh para remaja. Dimulai dengan suatu konsep yang diperkenalkan oleh Havighurst pada tahun 1951. Menurut Oerter (1985), dalam proses perkembangan selama rentang kehidupannya, seorang individu harus menguasai serangkaian "tugas-tugas perkembangan" yang muncul dari konstelasi-konstelasi khusus yang disebabkan oleh tekanan kematangan fisik, pengaruh-pengaruh sosio-kultural, dan kemampuankemampuan serta aspirasi-aspirasi individual. Beberapa contoh tugas perkembangan untuk masa remaja adalah : menerima dirinya sendiri, belajar mengenai peran sosial sebagai laki-laki atau perempuan, memilih dan bersiap-siap untuk menjalankan suatu pekerjaan, 
mencapai kebebasan emosional dari orang tua dan orang-orang dewasa lainnya, menentuka skala nilai dan sistem nilai untuk menjalani kehidupan. Tugas-tugas in dianggap sebagai peletakan dasar bagi perkembangan selanjutnya: "suatu tugas, yang timbul pada suatu periode tertentu dalam kehidupan seorang individu. Apabila tugas tersebut berhasil diselesaikan, akan membawa kepada kebahagiaan dan keberhasilan penyelesaian tugas-tugas selanjutnya, sedangkan kegagalan-kegagalan akan membawa ketidakbahagiaan dalam diri individu, misalnya berupa celaan dari masyarakat, dan atau kesulitan menghadapi tugas-tugas selanjutnya" (Havighurst, 1956).

Oerter (1986), mengungkapkan istilah tugas perkembangan dengan mengacu pada ruang lingkup yang lebih luas, yaitu:

1) Periode-periode dalam rentang kehidupan.

2) Tugas-tugas khusus yang terjadi secara normatif dan telah ada berdasarkan periode-periode dari rentang kehidupan.

3) Kejadian kehidupan kritis yang diantisipasi lebih bersifat umum.

4) Rentang dari kemungkinan-kemungkinan yang terjadi dalam perkembangan.

Oerter (1978) memformulasikan kembali konsep tugas perkembangan untuk mengoperasionalkannya dalam penelitian empiris dengan menggunakan tiga komponen tugas perkembangan dari Havighurst. Oerter menurunkan model tunggal untuk menggabngkan ketiga komponen, yaitu:

1) Fungsi dan struktur biologis individu.

2) Lingkungan khusus dalam kehidupan individu yaitu tugas yang timbul terutama dari tekanan masyarakat.

3) Nilai-nilai dan aspirasi pribadi dari individu. 
Pada model tugas-tugas perkembangan yang berdimensi satu dan bersifat kuantitatif (bagan 1), ketiga komponen tugas perkembangan Oerter dijadikan suatu dinamika sebagai berikut:

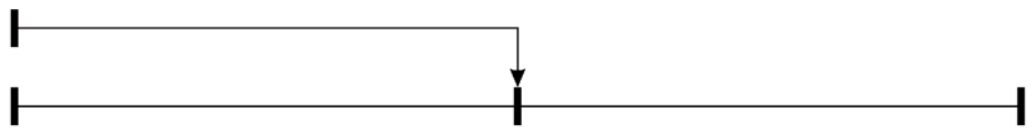

Kemampuan individu Tujuan perkembangan sebagai Norma sosial budaya (status perkembangan perangkat individu, untuk taraf dari perkembangan yang nyata) perkembangan yang diinginkan

Gambar 14: Dimensi Tugas Perkembangan Menurut Oerter

Garis di atas menggambarkan jarak perkembangan antara kemampuan nyata individu dan norma sosial budaya. Tujuan perkembangan menggambarkan tujuan yang secara nyata ditetapkan oleh individu untuk mengurangi jarak perkembangan. 


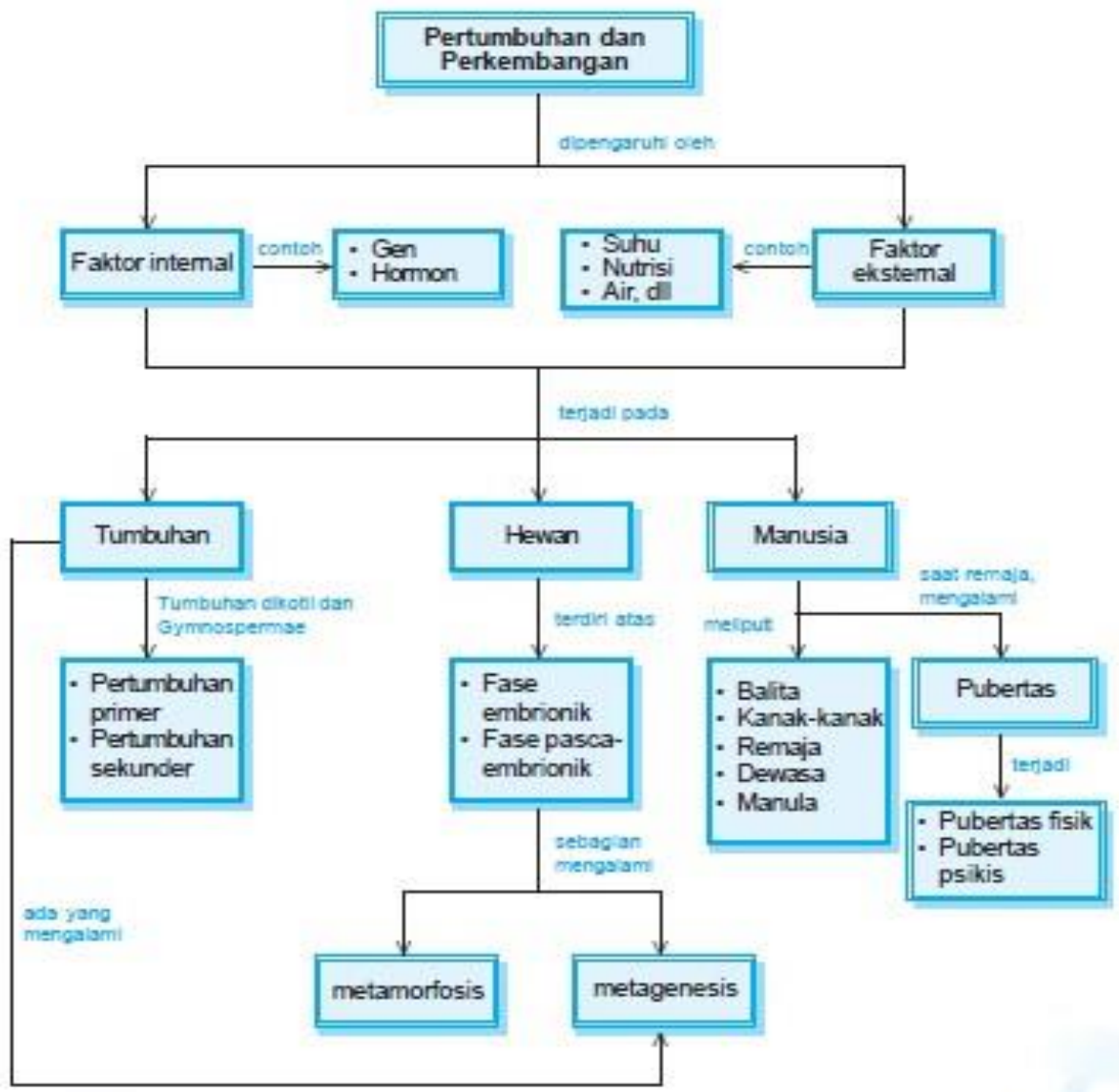

Gambar 15. Jarak Perkembangan Individu

Dalam banyak kasus, jarak antara tujuan individu dan norma perkembangan jatuh bertepatan (jarak nol). Menurut Oerter perkembangan individu mempengaruhi wilayah dari kekuatan kedua komponen lainnya di mana satu sama lain mengalami perubahan setiap waktu. Status perkembangan saat ini dan tuntutan sosial, juga berhubungan dengan adanya hasrat pencapaian dari tahapan 
perkembangan saat ini, atau lebih jelas lagi untuk tingkat perkembangan berikutnya. Pada usia-usia awal, anak tertarik untuk aktif dalam proses perkembangan, anak mencoba untuk mengurangi jarak antara status dirinya saat ini dengan harapan lingkungan. Dengan demikian langkah untuk menjelaskan hal ini dibagi tiga, yaitu:

1) Anak bergerak aktif untuk perkembangan dirinya dalam menentukan dan mengukur status perkembangannya saat ini dan perkembangan yang diharapkan oleh lingkungan sosialnya.

2) Memperkirakan jarak antara kemampuan diri dengan normanorma sosiokultural untuk menyesuaikan diri.

3) Dalam proses perkembangan seorang anak melibatkan tujuan dari tindakan.

Konsep Tugas Perkembangan Remaja dari Oerter, awalnya mengacu pada Konsep Tugas Perkembangan Havighurst. Upaya untuk membuat penjelasan secara dinamik dilakukan dengan menggunakan pendekatan action theory. Pada mulanya pendekatan ekologi digunakan untuk membahas konsep tugas perkembangan yang ditawarkan oleh Vygotsky bahwa hubungan anak dengan lingkungan berubah dengan meningkatnya usia. Dengan demikian pengaruh lingkungan ditentukan oleh pengalaman anak.

Proses pembelajaran yang berlangsung disekolah-sekolah pada saat ini masih cenderung berlangsung secara klasikal yang artinya seorang pendidik menghadapi 30-40 peserta didik dalam satu kelas. Dan pendidik masih saja menggunakan metode yang sama kepada seluruh peserta didik dalam kegiatan pembelajaran dikelas. Bahkan pendidik memperlakukan semua peserta didiknya secra merata tanpa pendidik memperhatikan latar belakang sosial budaya, kemampuan individual dan segala perbedaan tentang individual peserta didik. Setiap peserta didik pasti memiliki cirri-ciri pembawaa yang berbeda. Ada peserta didik yang mempunyai badan tinggi kurus, gemuk pendek, 
ada yang cekatan, lincah, periang, ada pula yang lamban, mudah tersinggung, dan beberapa sifat-sifat individual yang berbeda. Oleh karena itu untuk memberikan bantuan kepada peserta didik agar dapat mengikuti kegiatan pembelajaran yang disajikan oleh pendidik, maka pendidik harus benar-benar bisa memahami karakter peserta didik atau ciri-ciri para peserta didik. Begitu pula pendidik juga harus mampu mengatur kegiatan pembelajaran, dimulai dari perencanaan, proses pelaksanaan sampai pada tahap terakhir yaitu tahap evaluasi, sehingga peserta didik secara keseluruhan bisa mengikuti proses kegiatan pembelajaran dengan baik tanpa perbedaan yang berarti walaupun dari latar belakang dan kemampuan yang berbeda. Perbedaan individual harus menjadi perhatian bagi pendidik untuk mempersiapkan kegiatan pembelajaran yang akan dilakukan didalam kelas. Karena perbedaan individual merupakan suatu prinsip dalam kegiatan pembelajaran yang tidak boleh dihiraukan demi keberhasilan dalam proses kegiatan pembelajaran (Rohani, 2004).

Gagne, dalam Abdul Majid (2012) menganalogikan belajar merupakan sebuah proses membangun sebuah replika gedung, dimana anak-anak terus-menerus membangun makna baru (pengetahuan, sikap dan ketrampilan) berdasarkan apa yang telah mereka kuasai sebelumnya. Anak atau peserta didik adalah manusia yang membangun. Makna yang terkandung di dalamnya adalah apa yang mereka bangun. Apa yang mereka kuasai sebagai modal awal bagi mereka untuk membangun sebuah gedung baru tersebut.

Pembelajaran merupakan faktor yang sangat penting dalam perkembangan kehidupan manusia. Perkembangan merupakan hasil kumulatif dari pembelajaran. menurut Gagne dalam Jauhar (2011) menyatakan bahwa pembelajaran terjadi melalui proses penerimaan informasi, untuk kemudian diolah sehingga menghasilkan keluaran dalam bentuk hasil belajar. Dalam pengolahan informasi terjadi 
adanya interaksi antara kondisi-kondisi internal dan kondisi-kondisi eksternal individu.

Setiap siswa dalam proses belajarnya memiliki karakteristik yang berbeda dan semangat belajar masing-masing siswa juga berbeda. Dengan perbedaan karakteristik tersebut, maka salah satu solusinya adalah diadakannya metode pembelajaran yang dapat meningkatkan semangat belajar siswa. Proses pembelajaran dapat diikuti dengan baik dan menarik perhatian siswa, apabila menggunakan metode pembelajaran haruslah yang sesuai dengan tingkat perkembangan siswa dan sesuai dengan materi pembelajaran. Hal ini sesuai dengan pilar-pilar belajar yang ada dalam kurikulum pendidikan kita, salah satu pilar belajar adalah belajar untuk membangun dan menemukan jati diri,melalui proses pembelajaran yang aktif, kreatif, efektif, dan menyenangkan (Depdiknas, 2006). 


\section{ZPD dan Scaffolding}

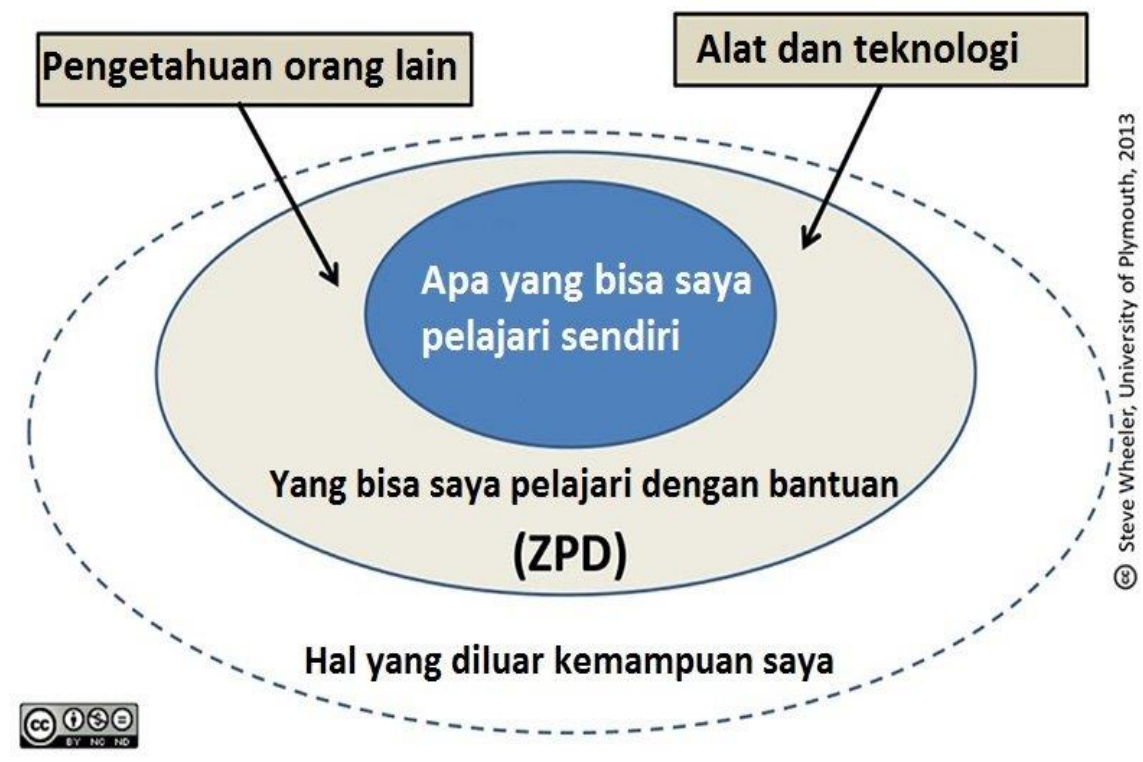

Gambar 16. ZPD dan Scaffolding Menurut Vygotsky

Zona Perkembangan Proksimal Teori Vygotsky mennyiratkan bahwa perkembangan kognisi dan kemampuan menggunakan pemikiran untuk mengendalikan tindakan kita sendiri lebih dahulu memerlukan penguasaan sistem komunikasi budaya dan kemudian belajar menggunakan sistem ini untuk mengatur proses pemikiran kita sendiri. Sumbangan terpenting teori Vygotsky ialah penekanan pada hakikat pembelajaran sosiobudaya (Karpov \& Haywood, 1998; Roth \& Lee 2007; Vygotsky, 1978). Dia percaya bahwa pembelajaran terjadi ketika anak-anak bekerja dalam zona perkembengan proksimal (zone of proximal development; proximal= berikutnya) mereka. Tugas-tugas dalam zona perkembangan proksimal adalah sesuatu yang masih 
belum dapat dikerjakan seorang anak sendirian tetapi benar-benar dapat dikerjakan dengan bentuan teman yang lebih kompeten atau prang dewasa. Maksudnya, zona perkembangan proksimal menjelaskan tugas yang masih belum dipelajari seorang anak tetapi sanggup dia pelajari pada waktu tertentu. Beberapa pendidik menyebut "saat pengajaran" (teachable moment) ketika seorang anak atau sekelompok anak berada tepat pada titik kesiapan untuk menerima konsep tertentu. Vygotsky lebih jauh percaya bahwa keberfungsian mental yang lebih tinggi biasanya terjadi pada percakapan dan kerja sama antar-orang sebelum hal itu terjadi pada diri individu.

Untuk itu, dalam pembelajaran di sekolah guru harus mampu mengaktifkan siswa selama proses pembelajaran dan mengurangi kecenderungan guru untuk mendominasi proses pembelajaran tersebut, sehingga ada perubahan dalam hal pembelajaran yang berikan yaitu pembelajaran yang berpusat pada guru sudah sewajarnya diubah menjadi berpusat pada siswa.

Pentanggaan merupakan gagasan yang berasal dari pendapat Vygotsky tentang pembelajaran sosial ialah pentanggaan (scaffolding; scaffold= tangga untuk pijakan tukang batu ketika membangun tembok) (Wood, Bruner \& Roos, 1976): bantuan yang disediakan teman yang lebih kompeten atau orang dewasa. Lazimnya, pentanggaan berarti menyediakan banyak dukungan kepada seorang anak selama tahap-tahap awal pembelajaran dan kemudian mengurangi dukungan dan meminta anak tersebut memikul tanggung jawab yang makin besar begitu dia sanggup. Orang tua menggunakan pentanggaan ketika mereka mengajari anak mereka menggunakan permainan baru atau ketika mengikat tali sepatunya (Rogoff, 2003).

Konsep terkait ialah pemagangan kognisi (cognitive apprenticeship), menjelaskan keseluruhan proses pencontohan, 
pembimbingan, pentanggaan, dan evaluasi yang lazim terlihat setiap kali berlangsung pengajaran perorangan (John-Steiner \& Mahn, 2003; Rogoff, 2003). Misalnya, dalam Life on the Mississippi, Mark Twain menjelaskan bagaimana dia diajari menjadi pengemudi kapal uap. Pertama-tama, pengemudi yang sudah berpengalaman memberitahukan kepadanya setiap tikungan di sungai tersebut, tetapi secara bertahap dia dibiarkan memikirkan sendiri segala sesuatu dan pengemudinya akan campur-tangan hanya jika kapal itu kira-kira akan kandas.

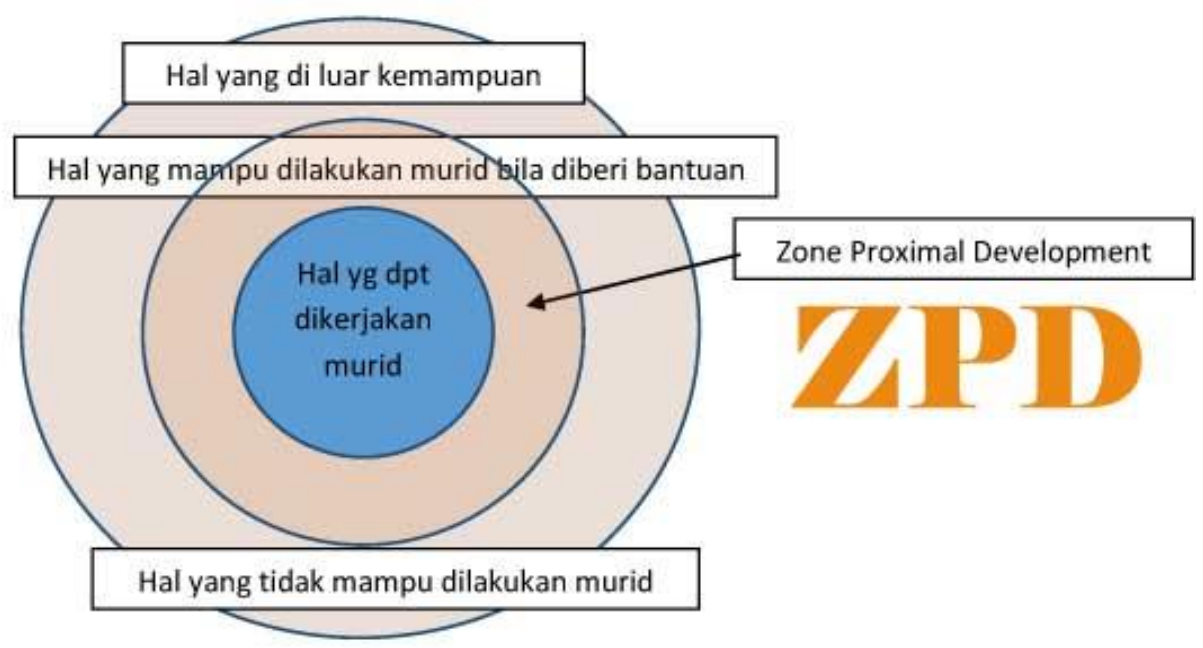

Gambar 17. Konsep Belajar Vygotsky

Konsep pengalaman dari Vygotsky merupakan realitas psikologi yang penting. Analisis pengalaman dimulai dari penelitian tentang peranan lingkungan dalam perkembangan anak. Pengalaman merupakan inti dari semua pengaruh yang berbeda-beda dari keadaan-keadaan internal dan eksternal. Pendidikan tidak boleh berorientasi pada fungsi-fungsi perkembangan yang telah terbentuk 
dan siklus perkembangan yang sudah berlaku, tapi harus berorientasi pada jenis-jenis pematangan. Kemungkinan memperoleh pendidikan terutama ditentukan oleh zona perkembangan proksimal.

Dengan menerapkan zona perkembangan proksimal pada pendidikan, pengajaran akan memajukan perkembangan, karena isi dari zona perkembangan proksimal diubah, diperbaiki, dikembangkan, dan ditempatkan pada tahapan perkembangan yang sebenarnya. Hal ini menyebabkan individu bergerak maju ke suatu tingkatan perkembangan yang lebih tinggi. Zona merefleksikan bidang kegiatan yang belum dikembangkan, tapi masih merupakan hal yang sedang berkembang. Zona itu menunjukkan kemampuan yang ada sekarang dan potensial. Berdasarkan penilaian ini, seseorang bisa membuat prediksi yang tepat secara ilmiah dan penentuan ari zona perkembangan proksimal membentuk "normative age diagnostics". Zona perkembangan proksimal juga digunakan sebagai suatu indikator dari perbedaan-perbedaan individual.

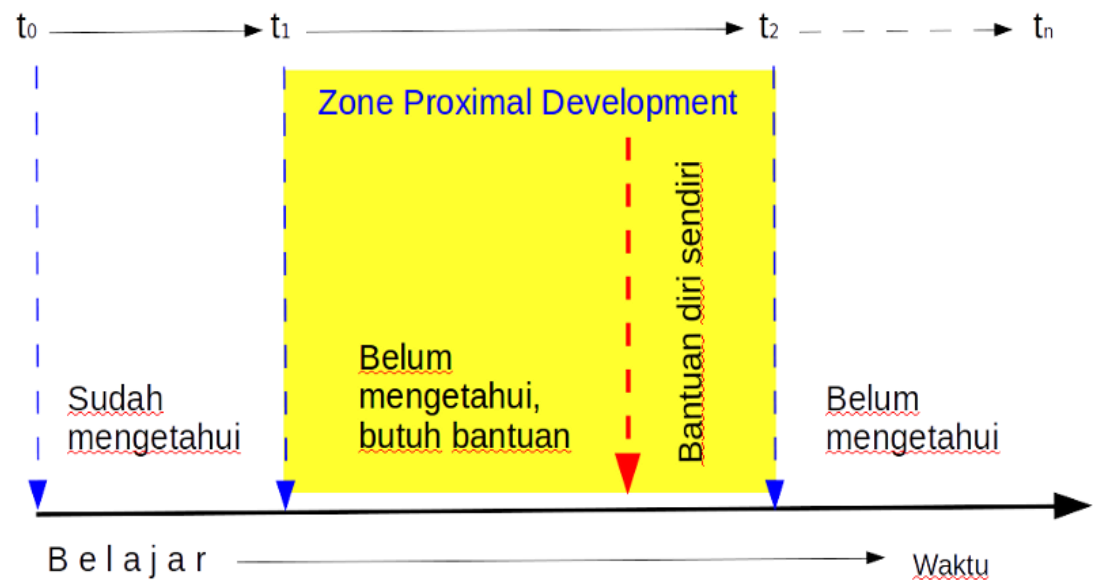

Gambar 18. Konsep ZPD

Belajar adalah suatu proses usaha yang dilakukan seseorang untuk memperoleh suatu perubahan tingkah laku yang baru secara 
keseluruhan sebagai hasil pengalamannya sendiri dalam interaksi dengan lingkungannya (Slameto, 2010). Sedangkan menurut Makmun (2007), belajar merupakan suatu proses perubahan perilaku atau pribadi seseorang berdasarkan praktik atau pengalaman tertentu. Senada dengan Skinner dalam Dimyati (2009) berpandangan bahwa belajar adalah suatu perilaku. Pada saat orang belajar maka responsnya menjadi lebih baik. Sebaliknya, bila ia tidak belajar maka responsnya akan menurun. Selain itu, Gagne dalam Rifa'i (2009) menyatakan bahwa belajar merupakan perubahan disposisi atau kecakapan manusia yang berlangsung selama periode waktu tertentu, dan perubahan perilku itu tidak berasal dari proses pertumbuhan.

Kimble (1961) mendefinisikan belajar sebagai perubahan yang relative permanen di dalam behavioral potentiality yang terjadi sebagai akibat dari reinforced practice (praktik yang diperkuat). Meskipun cukup popular, definisi ini tidak diterima secara universal. Pertama, belajar diukur berdasarkan perubahan dalam perilaku, artinya hasil belajar harus selalu diterjemahkan ke dalam bentuk perilaku atau tindakan yang dapat diamati. Kedua, perubahan behavioral relatif permanen artinya hanya sementara dan tidak menetap. Ketiga, perubahan perilaku itu tidak selalu terjadi secara langsung setelah proses belajar selesai. Kendati ada potensi untuk bertindak secara berbeda. Potensi bertindak ini mungkin tidak akan diterjemahkan ke dalam bentuk perilaku secara langsung. Keempat, perubahan perilaku berasal dari pengalaman atau praktik (latihan). Kelima, pangalaman atau latihan harus diperkuat; artinya hanya respon-respon yang menyebabkan penguatlah yang akan dipelajari. 
Eckensberger (1979) menjelaskan keterkaitan Action Theory dengan konsep tugas perkembangan dalam hal:

1) Budaya sebagai penghubungan antara individu dengan lingkungan.

2) Budaya sebagai inspirasi terjadinya aksi individu dalam suatu situasi.

3) Budaya sebagai kumpulan dari kondisi. Segall (1983-1984): kultur merupakan faktor tingkat tinggi yang tidak memiliki status independent variable, maka sangat tidak mungkin diukur. Maka dilakukan "Ecological Analysis", budaya dipecah-pecah menjadi faktor-faktor kontekstual, ide dasarnya adalah pembongkaran variabel-variabel budaya.

Bronfenbrenner menjelaskan pengaruh lingkungan terhadap perkembangan seseorang individu. lingkungan dibuat sistem-sistem yang diharapkan akan lebih memudahkan untuk menjelaskan pengaruhnyaterhadap perkembangan individu. bronfenbrenner (1989a dan 1989b) mengidentifikasi 4 (empat) cara yang dilakukan anak dalam menghadapi konteks sosial.

a. Atribut personal mendorong atau mengurangi reaksi dari orang lain yang memfasilitasi atau mengganggu perkembangan psikologis anak.

b. Sejak awal kehidupan, terdapat pebedaan individual dalam diri anak untuk mendekati atau menolak aspek-aspek tertentu dari lingkungan sosial maupun fisik. Kondisi ini membawa konsekwensi berkembangnya keterampilan maupun perbedaan cara belajar yang dilakukan oleh anak.

c. Pada diri anak terdapat individual, namun tiap anak tetap melakukan kegiatan yang kompleks. Contoh, melakukan elaborasi, menstrukturkan kembali dan juga menghasilkan keistimewaan baru dalam lingkungannya. Perbedaan dalam kreativitas dan 
kebutuhan untuk berubah juga berpengaruh pada "setting" yang dipilih oleh anak.

d. Dalam upaya mengontrol keberhasilan dan juga kegagalan yang dilakukan oleh anak, perbedaan usia menjadi dasar bagi anak untuk mengetahui kekuatan dan keinginan dari dirinya.

Oerter (1986), membuat bahasan tentang konsep tugas perkembangan dengan mengacu pada penjelasan Vygotsky, Havighurst, Eckensberger dan Bronfenbrenner. Oerter mengemukakan 4 proses dalam menjelaskan Konsep Tugas Perkembangan, yaitu:

1) Pegertian tujuan perkembangan.

Tujuan perkembangan individu berasal dari lingkungan.

2) Struktur objektif

Kemungkinan-kemungkinan tindakan anak disesuaikan dengan tuntutan yang telah terberi dari suatu lingkungan tertentu.

3) Struktur subjektif

Struktur dari individu mengenai pengetahuan, keterampilan, dan kemampuan-kemampuan yang dimilikinya.

4) Isomorfism struktur objektif dan struktur subjektif

Prinsip regulasi yang superior antara bekerjanya interaksi struktur subjektif dan struktur objektif, sehingga individu mampu membentuk kombinasi baru dan sampai pada sturktur unik dari tindakan.

Teman sebaya memiliki pengaruh yang besar terhadap perubahan perilaku individu. Teman sebaya juga dapat memberikan penguatan baik itu yang bersifat positif maupun negatif. Konseling sebaya berpotensi akan memberikan penguatan yang bersifat positif, yakni bagaimana seorang teman bisa menjadi motivator teman Lainnya. Implementasi yang dimaksud dalam penelitian ini merupakan pelaksanaan layanan bimbingan konseling sebaya. Konseling sebaya (peer counseling) adalah bantuan konseling yang di berikan oleh 
teman sebaya yang telah terlebih dahulu diberikan pelatihan untuk menjadi konselor sebaya, sehingga dapat memberikan bantuan baik secara individual maupun kelompok. 


\section{Daftar Pustaka}

Arlhouns, J.F. 1995. Psikologi Tentang Penyesuaian dan Hubungan kemanusiaan (Terjemaham R.S. Satmoko). Semarang: IKIP Press.

Asrori, Mohammad. (2009) Psikologi remaja perkembangan peserta didik. Jakarta: PT bumi aksara.

Desmita.(2003). Psikologi Perkembangan Peserta Didik. Bandung: Remaja Rosdakarya

Dwi Hastuti. (2016). Strategi Pengembangan Harga Diri Anak Usia Dini. Jurnal Pendidikan Sekolah Dasar, 2(2), 38-44.

Fahyuni, E. F. (2016). Psikologi Belajar dan Mengajar (Kunci Sukses Guru dan Peserta didik dalam Interaksi Edukatif) (1st ed.). Sidoarjo: Nizamia Learning Center.

Fahyuni, E. F. (2018). Bimbingan dan Konseling Islami Di Sekolah. Sidoarjo: Umsida Press.

Gagne, R.M. (1998). Essentials of Learning for Instruction, Englewood Cliffs, NJ: Prentice-Hall.Inc

Hamzah. Uno. (2006). Orientasi Baru Dalam Psikology Perkembangan. Jakarta: Bumi Aksara

Hurlock. E. (1980) Development Psychology A-Life-Span Aprroach. New York: Mc-Graw-Hill, Inc

Makkar, Suresh. (2015). Problem of empty nest syndrome: an analysis and sugestion to bridle it. ADR Journal. 19-23 
Murni. (2017). Perkembangan fisik, kognitif, dan psikososial pada masa kanak-kanak awal 2-6 tahun. III, 19-33.

Myers, D.G (1996). Exploring Psychology. New York: Worth Publisher. Inc

Santrock, J,W. (1998). Adolescence. Boston: McGraw-Hill

Jatmika. (2010) Genk Remaja, Anak Haram Sejarah ataukah Korban Globalisasi?,(Yogyakarta:Kanisius, 2010)

Wijirahayu, A. K. (2016). Kelekatan ibu-anak, pertumbuhan anak, dan perkembangan sosial emosi anak usia prasekolah. Jur. IIm. Kel. \& Kons, 9(3), 171-182.

Oerter, Rolf. Agustiani. (1996). The Concept of Human Nature in East Asia: Etic and Emic Characteristics. Culture and Psychology. London and New Delhi: Sage

Vygotsky, L.S (1978). Minds of Society. London: Harvard University Press

Zarkasih, Putro. (2017). Memahami Ciri dan Tugas Perkembangan Masa Remaja. APLIKASIA: Jurnal Aplikasi Ilmu-ilmu Agama. Volume 17, Nomor 1, 2017| Page: 25-32 


\section{BIODATA PENULIS}

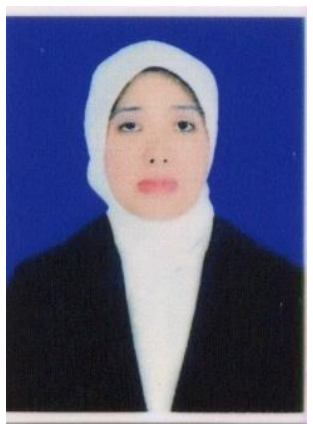

Dr. Eni Fariyatul Fahyuni, M.Pd.I dilahirkan di Sidoarjo, 04 November 1978. Penulis mendapatkan gelar Sarjana Psikologi, dari Universitas Islam Negeri Sunan Ampel Surabaya. Penulis melanjutkan studi magister Pendidikan Islam dan resmi mendakatkan gelar M.Pd.I di Universitas Muhammadiyah Sidoarjo. Penulis kemudian melanutkan studi Teknologi Pendidikan dan resmi mendapatkan gelar Doktor di Universitas Negeri Surabaya tahun 2018. Penulis mengawali kariernya sebagai Dosen di prodi pendidikan agama Islam Universitas Muhammadiyah Sidoarjo. Selain pendidikan dan pengajaran penulis juga terlibat dalam kegiatan penelitian dan pengabdian kepada masyarakat baik didanai oleh Ristekdikti maupun dana mandiri. Penulis juga aktif dalam mengikuti kegiatan-kegiatan penunjang akademik seperti seminar, workshop/ lokakarya, pelatihan serta pembimbingan tugas akhir dan kegiatan akademik. 


\section{D sikøløGi ERKEMBANGAN}

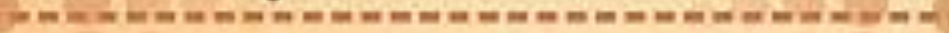

Buku Psikologi Petkenbangan isi menerangkan tahap-tahap : perkembangan nanusia dari awal sampai akhir kehidupannya atau sering disebut rentang hidup (life-span). Istilah perkembangan i berartiseraagkaian perubahan progresif yang terjadi sebagai ? akibat dari proses kematangan danpengalaman. Bukn ini jaga menjelaskan perkenbangan manusia yang bersifat kualitatif : pada fuagsi-fungsi jasmani,rohani,fisik dan mental sehingsa i dalam proses perkembangannya tidak semata-mata hanya terjadi perabahan bentuk fisik tetapi pola,cara dan persepsi i setiap individu dalan kehidupan sehari-hari. Ini baratti bahwa :

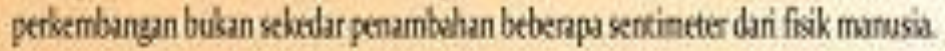

Mempelajari psilologi perkembangan dalam buku ini sangat bermanfaat bagi orang tua, pendidik, mahasiswa dan dosen. Perkembangan dan pertumbuhan manusia sesungguhnya tidak dapat dipisahkan karena keduanya saling beriringan. Jika salah satu tidak berfungsi dengan baik, maka perkembangannya dikatakan terhambat. Buku ini menyajikan berbagai informasi tentang bagaimana kita dapat memahami perkembangan i seseorang sehingga kita tabu card untuk membelajarkan mereka yang tentumya sesuai dengan bakat, minat, dan tahapan peekembangannya. 